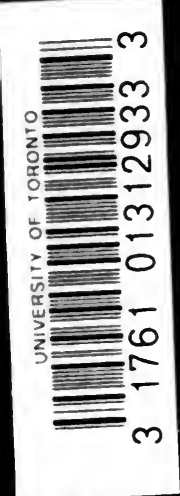

MODERNIZING
THE
MONROE DOCTRINE

MODERNIZING
THE
MONROE DOCTRINE

CHARLES H. SHERRILL

if

$x$ 


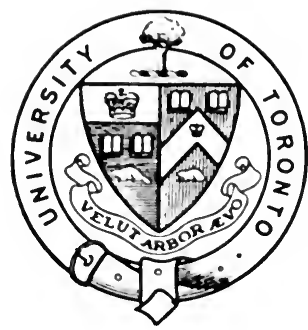

Presented to the

UNIVERSITY OF TORONTO

LIBRARY

\author{
by the
}

ONTARIO LEGISLATIVE

LIBRARY

1980 
.
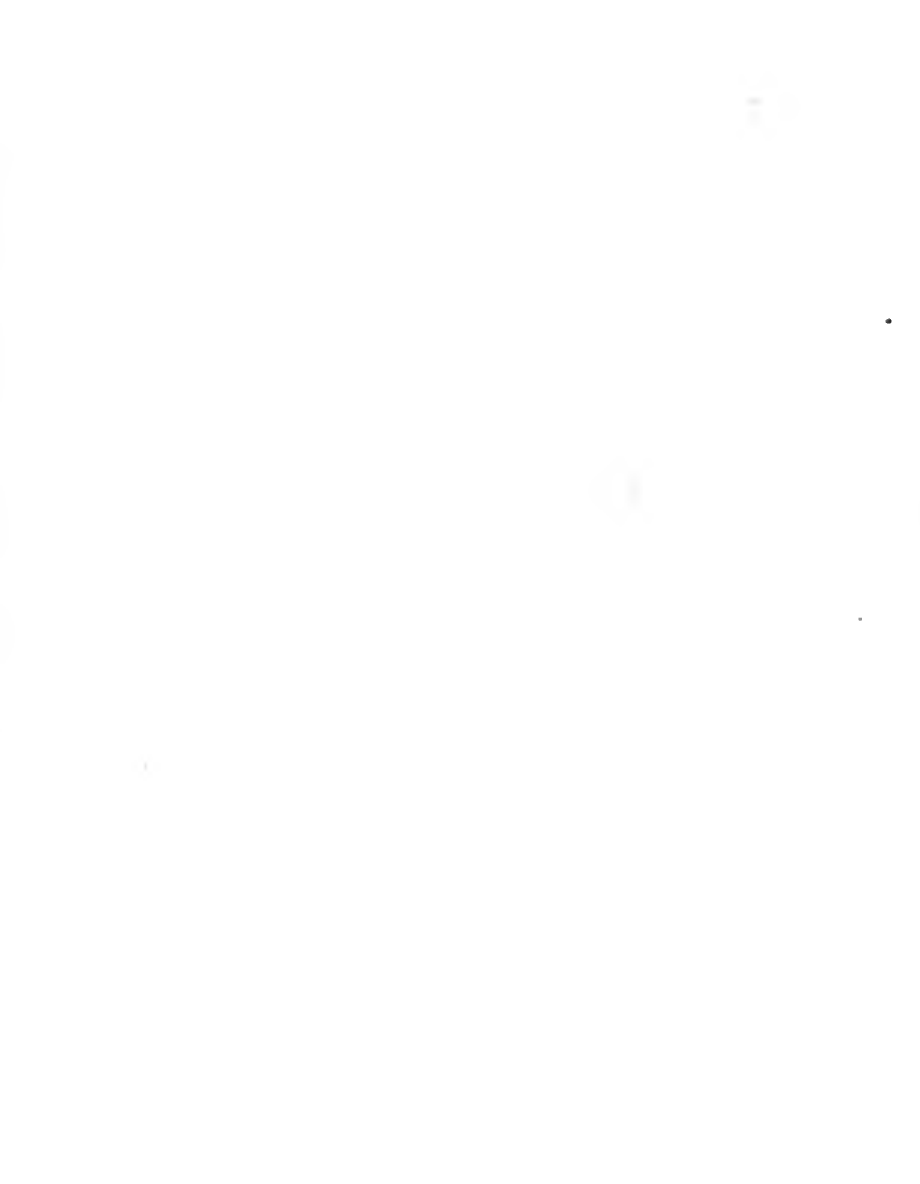

.

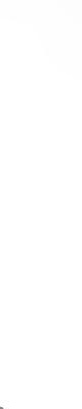



Digitized by the Internet Archive in 2007 with funding from Microsoft Corporation 


\section{0 the Same Autbor}

FRENCH MEMORIES OF I8TH CENTURY AMERICA.

STAINED GLASS TOURS IN FRANCE.

STAINED GLASS TOURS IN ENGLAND.

A STAINED GLASS TOUR IN ITALY. 
MODERNIZING THE MONROE DOCTRINE 



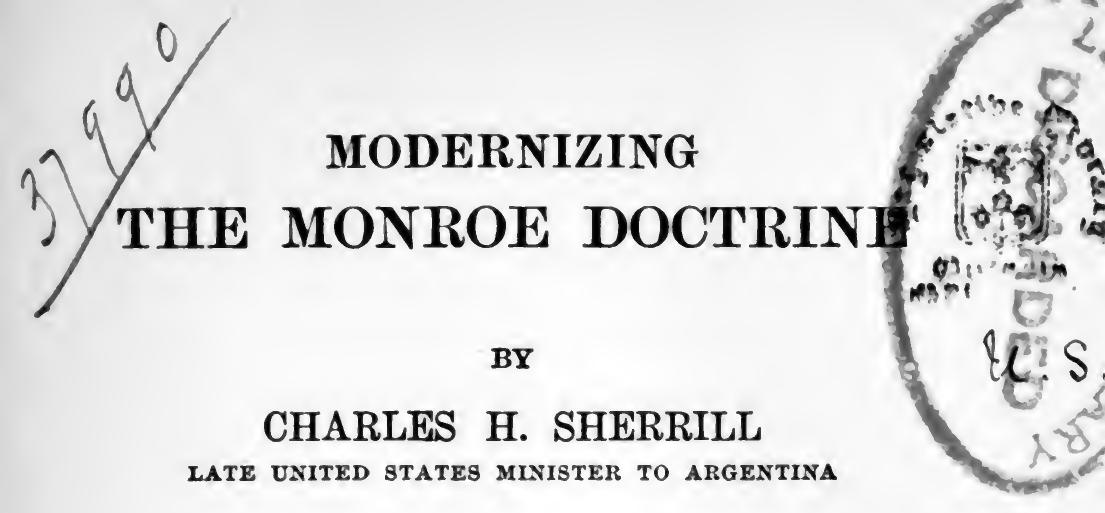

WITH AN INTRODUCTION BY

NICHOLAS MURRAY BUTLER

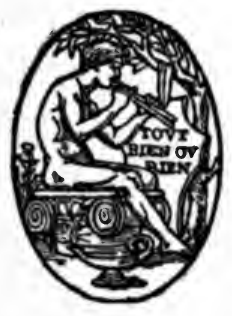

BOSTON AND NEW YORK

HOUGHTON MIFFLIN COMPANY

Cbe tabersioe press Cambribge

1916
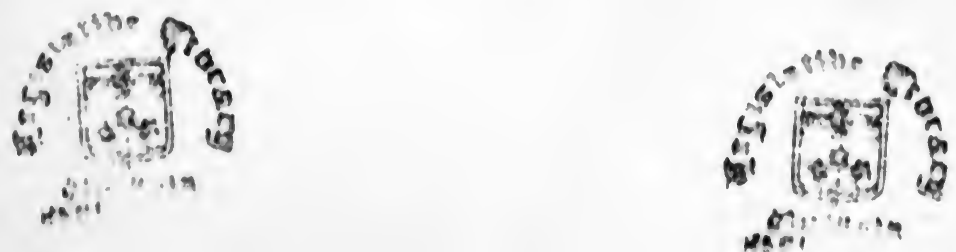
COPYRIGHT, 1916, BY CHARLES H. SHERRILL

ALL RIGHTS RESHRVED

Published March squb 
TO MY LITTLE SON GIBBS WYNKOOP SHERRILL AND THE MEN OF HIS GENERATION 



\section{PREFACE}

I believe in Pan-Americanism and its great future because it is at the same time the most altruistic and the most practical foreign policy to which any country has ever devoted itself. It honorably reconciles the two seemingly irreconcilable shibboleths, "Safety First" and "America First," because it satisfies both our patriotism and our desire for security. It is based upon a study of and a regard for the viewpoint of other nations, thus educating the spirit of our own nation: advance the spiritual side of a whole people and things material will take care of themselves. It provides a definite foreign policy upon which the most practical of men may consistently unite with extreme idealists. It is an attempt to assemble the finest traits of twenty-one republics so as to employ them in combination for the common good of all, meanwhile disregarding their shortcomings: this mixture of appreciation and toleration will surely be as effective when applied in the family of nations as it has proved in many a family of individuals. Once this attitude of mind is gained, it matters little how much the republics concerned differ in racial traits. Pan-Americanism makes for a broader and deeper type of patriotism, because it adds a consideration for the viewpoint of other nations to the nar-

$$
\text { vii }
$$


rower and often selfish patriotism for one's homeland, whose interests nevertheless it safeguards. It is the lineal descendant of the Spirit of '76, whose Source was acknowledged by those armed Americans who at daybreak knelt in prayer on Cambridge Green before marching out to defend Bunker Hill.

Some policies are only beneficial when completely worked out, but Pan-Americanism, even when incomplete, is beneficial, and complete, it would be an immeasurable blessing. It is the most practical agent for international peace thus far devised. By means of joint mediation by American republics it has already prevented a conflict between the United States and Mexico, and upon that achievement as a base, let us erect a completed triangle, whose easterly side shall protect us from future friction with Europe, and whose westerly side insure peace on the Pacific; thus shall we have a Pan-American Triangle for Peace. The responsibility for Pan-Americanism is a continental one. The responsibility for the Monroe Doctrine will always be peculiarly our own, though it may be shared in by others. Together they should be guaranteed by a strong navy both in the Atlantic and the Pacific Oceans, and by an adequate army with a citizen reserve trained as are the peace-loving Swiss.

Charles H. Sherrill.

20 EAst 65Th STREet, New York City. 


\section{CONTENTS}

Introduction, by Nicholas Murray Butler - xi

I. What is South America like?. • • . 1

II. South American Markets: Commerce as an International Peacemaker . . . 17

III. Chambers of Commerce:'Therr Opportuntty for Patriotic Service Internationally as well as Nationally • • • • • 28

IV. Legislative Assistance needed by those entering the Foreign Field • • . 40

V. The South American Point of View: Is it WORTH CONSIDERING? . . . . . . 52

VI. Our Point of View misunderstood in Latin America: Pan-American Conferences CORRect Misunderstandings . • • . 64

VII. The Monroe Doctrine and the Canning Мүтн • • • . • . • . • . 77

ViII. The Monroe Doctrine and its Misinterpretation Abrond

IX. A Pan-American Triangle for Peace . 105 Its Base: Pan-American Jornt Mediation to prevent Wars in tuis HeMISPHERE

IX 


\section{CONTENTS}

X. Was the A.B.C. Mediation a Success? 120

Xi. A Pan-American Triangle for Peace . 133 Its Easterly Side: A Completed Monroe Doctrine to prevent Friction WITH EUROPE

XiI. The Panama Canal: its Part in Pan-AmerICANISM • • • • • • • • . 155

XIII. A Pan-American Triangle for Peace . 163 Its Wegterly Side: Practising across the Pacific what the Monroe DocTRINE PREACHES

XIV. A Strengthening of the Latin American MAP • • • • • • • • • 189 


\section{INTRODUCTION}

Is the following pages Mr. Sherrill offers a vigorous and stimulating discussion of some of the most interesting and most important questions that now confront the American people. He touches on many disputed points and makes some novel and even radical proposals. In doing these things he stimulates and indeed compels the reader to think for himself on questions of international politics, and this is just now the most crying need of the American people.

Circumstances over which we have had no control, and conditions which we have been powerless to change, have completely altered the relation of the United States to the rest of the world during the lifetime of the present generation. International trade we have always had more or less, and the tide of immigration has flowed strongly toward our shores for the greater part of a century. Science, which knows no national boundaries and no limitations of language, has always been a force making for international appreciation and understanding, as have the fine arts, while literature has lagged only a little distance behind. The world had been internationalized almost without our knowing it, and when the storm of 
war broke with frightful suddenness on August 1, 1914, it found in operation a silent but powerful system of international intercourse and international dependence of which it straightway made a complete and costly wreck. Americans, who had never before thought of the world outside the limits of their own countries as other than part of another and distant planet, were forced to appreciate that they, too, were bound to men and women whom they had never seen and whose language they had never heard, by invisible ties that only a world-war could break or destroy. In a twinkling of an eye international shipping, international trade, international finance, international communication of every sort fell from their place of high security and comfort to positions of the utmost danger and damage. This was as emphatic and as severe a lesson in what internationalism means as the world, including America, has ever received.

Mr. Sherrill deals chiefly, as the title of this book directly suggests, with problems of the American continent and with other international problems that grow out of these. The present is the psychological moment to draw the Republics of the three Americas together, since they are all alike removed from the immediate theatre of the world-war. They are all alike republican in their form of government, and they are all alike dealing with the problems that face new peoples with fresh soil and unexhausted natural 


\section{INTRODUCTION}

resources. It would be a mistake, however, to suppose that the several American Republics in drawing closer together are thereby thrown in contrast with the older nations of Europe and of Asia, or are in any way to be brought in antagonism to these. On the contrary, the drawing together of the Republics of the three Americas should be rather a symbol of that greater and larger drawing together which the whole world will one day witness. The war may postpone, but cannot wholly prevent, the march of the human spirit toward its ideals of universal brotherhood, with liberty and justice assured to all men. There are not two worlds, an American world and a non-American world, but only one, and the part which the Americas will play in that one world will depend upon their faithfulness to their own ideals and upon the sincerity and permanence of their feeling of comradeship for each other and of friendship for their brothers in other and older lands than their own.

If from these pages Americans shall learn to look out across the waters that bound them on the east and west and south, and if they learn that it should be quite possible for them to live in as great harmony and security with their neighbors overseas, as they do with their neighbors to the north, who are separated but by a long imaginary and quite undefended line, Mr. Sherrill may be happy indeed. In that case his years of diplomatic service, his close 
study of American commerce and its needs, and his earnest efforts to play the part of a high-minded American citizen, will not have been in vain.

The happiness of the world, as well as its peace, will be promoted when men learn to look at worldproblems not from the viewpoint of their own nation alone, but from that of other nations as well. Mr. Sherrill's book will help Americans to see the worldproblems as other peoples see them.

Nicholas Murray Butler

Colombia Untversitry,

Eebruary 1, 1916 
MODERNIZING THE MONROE DOCTRINE 



\section{MODERNIZING \\ THE MONROE DOCTRINE}

\section{CHAPTER I}

\section{WHAT IS SOUTH AMERICA LIKE?}

IT is not difficult to find scores of our fellow citizens qualified to discourse knowingly and in detail of Europe, its cities, its peoples, its life, and its civilization. But how few, how pitifully few of us know anything at all about Latin America, and most of that few have gathered their meagre store of information through a winter trip to the West Indies, the Panama Canal, or certain northern ports of South America. The result is that as a nation we are either ignorant of our neighbors of the great Southland, or else we picture them in a landscape of palms beneath the sultry rays of a tropical sun, rolling cigarettes, and occasionally ejaculating, “mañana"! Sometimes this languid scene is enlivened by a revolution. But this picture is as far from the real facts as are most pictures painted by ignorant artists.

On the subject of revolutions I am perhaps a prejudiced witness, for although there were none to be seen during my two years' stay in South America, 
I landed in the midst of one in Lisbon on my way home. Think of haying to go all the way from the River Plate to Europe to find a revolution! There is no more chance of a revolution in such countries as Argentina and Uruguay than there is in Brooklyn. Nor is it in that revolutionary detail alone that this conventional picture of South Americans is incorrect. Too long we have stood off and looked at them from a distance through a telescope whose nearer lens was obscured by tropical foliage. It is a mistake to believe them as all enervated by a torrid climate; we have forgotten, or never known, that much of their continent lies either in a temperate zone or else so high above sea level as to gain a temperate climate. Most of Ecuador, lying immediately under the Equator, is saved from an equatorial temperature by the fact that it has an altitude of ten thousand feet. A similar elevation above sea level saves many other portions of central and northerly South America from a tropical climate. So that while it is true that some of the lands bordering the Caribbean Sea are subject to high temperatures, the great bulk of South America enjoys, as we do, the energizing climate which goes with temperate latitudes, notwithstanding their position on the map would seem to indicate otherwise.

Although it is, of course, impossible in the space of one chapter fully to answer so comprehensive a 
question as "What is South America like?" enough can be said to show how utterly mistaken is the general idea now prevailing among us of those lands and their peoples. Perhaps what we shall say will be less a description than a protest (with specifications) against an accepted error. It ought to be enough to open some eyes, or at least to make their owners want to open and use them. Unfortunately, the writer has not visited all the South American republics, and can tell only of what he has seen. Nevertheless, any one who happened to be in Buenos Aires during the year 1910 had the unique opportunity there presented of meeting the leading statesmen and thinkers of all Latin America assembled in that city, not once but four times, for the Centennial Anniversary of Argentine Independence, for the Fourth Pan-American Congress, for the Pan-American Scientific Congress, and for the Congress of American students. The writer was there and enjoyed the great privilege of acquaintance with all those delegates and friendship with many of them. This will easily explain why he so thoroughly likes Latin Americans - he knows them!

But let us, in orderly fashion, begin our investigation at the beginning and learn something of our journey toward the peoples we are about to like, for like them you must if you come with me. We will soon decide that the travelling necessary to reach

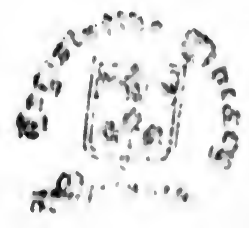


them is as agreeable as the nearer view of them is attractive. The Garden of Eden might not be worth visiting if one had to reach it on foot over a desert, but it is difficult to imagine a pleasanter journey than that which takes us down to Buenos Aires. Starting from our own ports the continent of South America will be reached after a charming voyage through the West Indies. For those going from English or other European ports, the journey will be broken by eight whole daytimes ashore. In this way the traveller will have time to see Vigo in northern Spain and its wonderful harbor, quaint old Lisbon, and Funchal in the Madeira Islands, one of the beauty spots of the world. Then follow six days devoted to crossing the Atlantic and to incessant deck sports, after which the two streams of travel (from the United States and from Europe) join at Pernambuco, the Venice of Brazil, and continue down the coast together, stopping at Bahia, the seaport of the country from which come the Brazilian diamonds, and then Rio de Janeiro, the beauty of whose famous harbor must be seen to be realized, and cannot be described either by pen or photograph, so amazing is the huge circle of tropical vegetation dotted with conical, sugarloaf hills, and all active with many signs of the prosperity belonging to a great city.

From Rio de Janeiro we drop down to Santos, 
out through whose sequestered, river-approached harbor comes sixty per cent of all the coffee that the world drinks. Then a long pull of five days down the coast to Montevideo, a typically Spanish-American city of about 300,000 inhabitants stationed at the mouth of the vast Rio de la Plata. One hundred and twenty-five miles up this river lies Buenos Aires, the metropolis of Argentina, its population of nearly 2,000,000 making it the second largest Latin city and one of the world's greatest capitals. Even as high up as Buenos Aires, one hundred and twenty-five miles from the ocean, the river is thirty miles broad. Until we arrive there everything we have seen has been Spanish-American, but Buenos Aires looks thoroughly European and will seem very familiar to any one who knows Vienna or Brussels.

It is not difficult to draw with figures what might be called a chart of the material importance of SouthAmerican countries. The year before the European War broke out the foreign trade of Argentina amounted to about $\$ 1,000,000,000$, that of Brazil to about $\$ 500,000,000$, of Chile, $\$ 200,000,000$, of Uruguay, $\$ 100,000,000$, while all other South American countries were below this last figure. This shows at a glance how the countries rate from the standpoint of material importance, and Argentina's lead is accentuated if we reflect that it has about 9,000,000 population as against Brazil's 21,000,000, 
although its foreign trade is double that of the latter country.

It is not strange that this material importance of Argentina should be reflected in its great capital city. It is not a picturesque country as are the tropical ones through which we must pass to reach it. Far from it. Try to imagine a huge flat plain, slightly larger than the United States east of the Mississippi. Its railroads, built on a broader gauge than ours, are comfortably equipped after the European manner, sleeping-compartments taking the place of the unhygienic and mediæval sleeping-car berths which for some strange reason we still endure in our country. If we leave Buenos Aires on an express train going toward the Andes, it will take eighteen hours to reach the first roll of the foothills. In all this distance you will run over a flat expanse devoid of trees, peopled, as far as the eye can reach on each side, by vast herds of cattle. What you are seeing will explain the great wealth of the country, for from this vast alluvial plain come the tremendous crops of wheat and other grain and that by-product of agriculture that we call the cattle industry. All these products feed into Buenos Aires and out through that great port.

Wealth is more evenly distributed in Argentina than it is in our country and the expense of living there is very great. There is no club in New York 


\section{WHAT IS SOUTH AMERICA LIKE?}

City whose initiation fee is larger than three hundred dollars, and yet the initiation fee of the principal club in Buenos Aires is fifteen hundred dollars gold and the club has two thousand members! During my two years there I never saw a man intoxicated on the street; I never saw a beggar; and even the poorest people wore good shoes. Imagine a city of nearly two million inhabitants with no slums!

In 1910 there was celebrated the Centennial Anniversary of Argentine Independence, an occasion of such importance as to cause five of the greatest Powers to send special ambassadors and fleets to represent them, which example was followed in more modest fashion by many of the other Powers. During the three weeks of this Centennial the city of Buenos Aires spent $\$ 3,000,000$ on street-lighting alone, which will give some idea of the ample and lavish way in which public entertainments are there conducted.

Most of us have forgotten since our school days that the seasons of the Southern Hemisphere are the reverse of those in the Northern Hemisphere. During our winter they are having summer, and when we are sweltering, they are cool. This has worked to the advantage of the South Americans in many ways. For instance, Buenos Aires is accustomed to borrow from the city of Paris its municipal architect, who, at the conclusion of his winter duties in 
Paris, can cross the Equator and find another winter awaiting him. It is upon his advice that the Argentines conduct all improvements in their great capital.

Another advantage which they enjoy from this difference in seasons is that it enables them to hear during their winter all of the best opera singers of Europe and our country, because, having concluded their engagements with us, they are free to go South for six months. Nor do they await our approval to employ, an artist, for they had Caruso in Buenos Aires two years before he sang in New York, and that also is true of Titta Ruffo and other stars. The Opera House in Buenos Aires is much finer and in distinctly better taste than ours in New York. It combines our "horseshoe" of boxes with the airy grandeur of the stairway and foyer of the Paris Opera. Instead of wearily waiting at the door, as in New York, for half an hour or more to get one's motor, there are several driveways passing under their Opera House, each permitting many motors to be filled at once and sent on their way without ever exposing one to the weather.

Another of the many surprises Buenos Aires has in store for the complacent foreigner, satisfied that our great northern cities have nothing to learn, will be provided by the point to which the Argentines have developed the department-store idea. Gath \& 


\section{WHAT IS SOUTH AMERICA LIKE?}

Chaves are not content with one great store only, but have several of them, each in a different part of the city, and each specializing, one devoted to clothing, another to household supplies, etc. The hotels are modern and some of them luxurious. The Plaza Hotel is as up-to-date as any of ours, and is run like any other of the Ritz hotels in New York, London, or Paris. They have a better subway than we have in New York City.

In the tropical countries of South America, of course, they have their rainy season and their dry season, but in Buenos Aires the weather is that which is advertised for the French Riviera, but which most people fail to find there! There is a great deal of sunshine. In winter it gets cold, but never quite reaches freezing, and in summer the thermometer seldom registers ninety degrees.

The people of the country are a useful mixture of Latins, chiefly from northern Spain and northern Italy. Argentina receives about 250,000 immigrants a year, half Spanish and half Italian. These immigrants are admirably received by the Government, landed, housed, fed, and distributed free of expense to different parts of the country. During the year 1910 the immigrants were distributed among one thousand and eleven different inland points instead of being allowed to segregate in the capital.

Argentines are more interested in form than in 


\section{MODERNIZING THE MONROE DOCTRINE}

color. Their flag is light blue and white, and this seems to typify the land and its tastes. Everywhere you see grays and light browns and dull tones of the other colors. An Italian immigrant arrives with gaudy neckerchief, but soon discards it for something more in accord with his new surroundings. The women of Argentina dress extremely well, but they, too, reflect the national antipathy for the gaudy. Nowhere will you see a better and more quietly dressed assemblage than in the enclosure of the Jockey Club at the famous Buenos Aires RaceTrack. All of the grand-stands are of concrete, and at the top of the private grand-stand of the Club is a dining-room, seating two hundred people, which has glass sides, thus enabling those at luncheon to watch the races. The show-ring of the Agricultural Society is the finest structure of its kind in the world and cost $\$ 4,000,000$.

The most popular sport in Argentina is Association football, what our English friends call "soccer." Just as in the spring and summer every vacant lot with us is full of boys playing baseball, so in Argentina all the boys and young men are kicking footballs at "soccer" goals. University sport is as yet undeveloped, but the matches between clubs are keenly contested, and fine teams result. When the English professional champions visited Buenos Aires, they had their hands full to win, the score against the 
best Argentine team being but 4 to 3 . Out at the Tigre, a delightful inlet of the River Plate strongly reminiscent of the Thames at Henley, there are many boat-clubs, and their eight-oared shell crews are well coached and show fine form.

The constitutions of almost all South-American countries are modelled upon our own, but in many instances show an improvement upon ours. In Argentina, for instance, the presidential term is limited to six years and a president cannot be immediately reëlected, it being believed that it is inexpedient to permit an executive to use the federal "office-holding machine" to secure his reëlection. In Argentina voting is obligatory and a man who does not vote is blacklisted and is fined the equivalent of $\$ 4.40$ of our money.

It must be admitted that this advanced stand taken by Argentina in the matter of voting does not represent the general status concerning the franchise in all her sister republics. We have indulged in much unfriendly and injudicious criticism of the fact that the uneducated peons of certain of those countries are not allowed to vote. That is none of our business, and what is more, how would we like it if some Mexican newspaper persisted in reiterating something like this: "Frightful conditions of the negro voters in the United States. In many sections the well-to-do whites will not permit their colored fellow-citizens 
to vote. By their latest apportionment each Congressional District in 1914 contained 211,877 citizens, but notwithstanding the fact that throughout the North and West large numbers of votes were cast in each Congressional District (64,775 in the 3d Ohio District, 62,987 in the 7th Indiana, 56,907 in the 7th Illinois, etc.) in the Southern States, by keeping from the polls the negro voters, it is but seldom that more than 5000 votes are cast per district, - both Georgia and Arkansas having several districts casting less than 5000 votes, Florida having only one casting more than that number; the 4th Louisiana cast 3454, the 5th Louisiana 3014," etc., etc. How would we like such criticisms, such interference by foreigners! People who live in such an electoral glass house as permits only 3000 out of 211,877 to vote for a Congressman had better not throw stones at the voting habits of any Latin-American republic. Besides, the governmental system of any other sovereign country is none of our business.

Sometimes a well-conceived law yields in its operation certain benefits not expected by the lawmakers. An example of this sort is afforded by the Argentine statute which annually calls to active service with the colors about 12,000 young men. One can escape this call by qualifying as a sharpshooter. This results in a desire among the Argentine youth to attain skill with the rifle. They are frequently to be seen 
practising this sport at the many shooting ranges provided by the Government, and a comparison between the proportion of Argentine males who are good shots, and the proportion existing in our country, leaves us dishearteningly in the rear. Thus has a well-conceived law produced as a by-product a nation of riflemen.

Argentina has a Federal Government and State Governments just as we have, with Federal and State courts, etc. As a comment upon the purity of its Government, it is interesting to recall that at the conclusion in 1910 of the contest for the Argentine battleship contracts, amounting to $\$ 23,000,000$ (a contest participated in by thirty-seven firms representing seven nations), not even the opposition press was able to find anything irregular upon which to criticise the Administration for its award of those contracts to bidders from the United States. The whole transaction was as clean as it would have been if it had been conducted by our Federal Government or that of any of the leading European nations.

The greatest of all the South American liberators was the Argentine General José de San Martin, whose services to liberty in the South paralleled those of Washington in the North. Having freed his own land in 1816 he crossed the Andes and successively freed Chile, Peru, and Ecuador. When an enthusiastically grateful people wished to make him 


\section{MODERNIZING THE MONROE DOCTRINE}

a dictator, what did he reply? Listen to his splendid words, echoing down the years: "My promises to the countries in which I warred are fulfilled, to make them independent and leave to their will the elections of the governments." Did ever any AngloSaxon republican surpass this expression of confidence in the electoral franchise! San Martin resigned all honors, declined large offers of money grants, and retired to France to end his days in obscurity and poverty.

Fortunately for South America, it is the fashion to have large families. One of the Cabinet Ministers in Argentina had seventeen children, and when congratulated thereon he used to reply, with a twinkle in his eye, that he considered it but a good beginning! The wealthier the family the more children they are apt to have, which is unfortunately not true in our country. The rate of increase of native-born population among the Latins of the New World is higher than that of us Anglo-Saxons, and in a couple more generations this fact will have important results.

Of the hospitality and kindness to foreigners for which South America is noted, it is not necessary to speak. It is not only in the hearts of the people, but it is upon their statute books. For instance, any foreigner can go to Argentina and do business, either banking or otherwise, on exactly the same basis as a native-born citizen, which is not the treatment ac- 
corded by our laws to foreigners. About the only exception to this general rule is the fee charged commercial travellers. Of my personal relations with the Argentines let me say that no foreigner who has lived among them has ever returned to his home with a warmer affection for them than I entertain.

It is a great pity that we, as a nation, know so little about what South America is really like. But even some who are completely ignorant upon the subject are performing a useful service. There are of late certain authors who decry Pan-Americanism, - authors, by the way, who generally prove never to have lived among the Southern peoples about whom they write so freely, - but it seems to me that even these avowed enemies of our cause are helping us by directing public attention to the subject. They are really aiding and not injuring Pan-Americanism, because all it needs is to be studied. Known, it is its own most convincing advocate.

Before we attempt to prepare a plan which can hope to safeguard the future peace of all the Americas, let us, in preparation for that task, consider the remarkable commercial advance of Latin America, because that may indicate how our commercial organizations can be of patriotic service to us in effecting better understandings throughout the New World. Next we should consider from various angles the Monroe Doctrine, so that by learning why it 


\section{MODERNIZING THE MONROE DOCTRINE}

has been misinterpreted abroad we may become equipped to outline certain additions and adjustments that will bring it up to date and prepare it to serve as a standard in confronting those problems which lie just before us. After these preparatory studies we shall, in Chapter IX, begin to suggest such an application of the principles of Pan-Americanism to our future as will afford a complete foreign policy of preparedness. 


\section{CHAPTER II}

SOUTH AMERICAN MARKETS: COMMERCE AS AN INTERNATIONAL PEACEMAKER

Commerce requires a knowledge of those with whom we would trade. One of the chief causes for international misunderstandings is the lack of appreciation by one nation of the real characteristics of the peoples of another nation - a lack of mutual acquaintance. Commerce makes for a better acquaintance, and therefore commerce is a peacemaker. The reason why our trade with South America lagged behind that of England and Germany is not far to seek, if one considers the appalling ignorance concerning our Southern neighbors that even yet prevails in our land, though not so generally as a few years ago. The chairman of a chamber of commerce meeting in a large New England city introduced me to the audience as coming "from Buenos Aires, a city whose population is over one hundred thousand." He was right; it has nearly two million. A plate-glass dealer wrote my Legation from Denver to inquire if the Buenos Aires shops used glass in their windows!

Some of the cities of our country have not yet been fully awakened to the value of foreign trade. Other cities, however, are already thoroughly aroused to 
the advantages which the export trade has for the manufacturer, but the causes for such an awakening are widely different in the various cities. In Cincinnati, for example, one of the reasons for the general interest in and knowledge of foreign trade came about in this way. During the business depression in the autumn of 1907, the Fay-Egan Company was running on full time, although most of the other manufacturing plants of that city were not. A little while before the company had decided that a "Foreign Department" would look well on their stationery and had therefore started to build up a small one. It had reached sufficient size by the autumn of 1907 to secure them enough business abroad to run their plant to its full capacity, just at a moment that business depression at home and shrinkage of domestic markets had cut down the orders of most other Cincinnati plants. This lesson was not wasted on the active-minded citizens of that city, with the result that many of their manufacturers have since built up a foreign department, if for no other purpose than to use it as an anchor to windward during dull times at home.

During my series of nearly two hundred speeches before commercial organizations upon the subject of foreign trade, I have frequently been asked how it can best be secured. Perhaps the best answer is to recall the ancient tale of the city boy who on his first 
visit to the country asked the farmer, "Do your cows give milk?" The farmer replied, "No, my little man, you have to go and take it away from them." Perhaps this story will seem more in point when you are told that in the city of Buenos Aires, that great world-market, there are forty thousand English, thirty-five thousand Germans, and thirty thousand French, while there are only about four hundred Americans. From this it is easy to see which nations have realized that you must go and take the milk away from the cow, and which nation has not as yet grasped that important fact.

Let us spend a minute in considering the markets of the world and inquiring the one from which a manufacturer newly interested in foreign trade may expect the most immediate returns. The most important markets may be roughly classified under three heads: those of Europe, of the Far East, and of Latin America. In what do they differ? The greatest attention of our exporters has hitherto been devoted to the European field. They have sent there their best agents, and although handsome results have been obtained, it is, of course, obvious that when we compete against Europeans in European markets, they have the advantage in customs, language, length of haul, and knowledge of local requirements. We are strangers competing with them on their home grounds. 


\section{MODERNIZING THE MONROE DOCTRINE}

When we turn from Europe to the markets of the Far East, we are still competing with the European, although the factor of the long haul is equalized, but there our exporters are handicapped by a lack of special detailed knowledge of market requirements which in that part of the world is peculiarly necessary. The Chinese and Japanese and Indians prefer to buy goods which they have seen before. They want their packages put up in the accustomed manner, and frequently insist that they shall bear special marks. It is a long and expensive business for an American exporter to learn enough of these special requirements to be able to compete on equal terms with the well-trained European salesman in the Far East.

Turning from these two great markets to those of South America, we find very different conditions prevailing, for the handicaps which hamper us elsewhere will not confront us in this portion of the world. In fact, we shall find that it is we who have an advantage because of the South Americans' great interest in novelties, and there are no people on the globe better equipped to produce novelties than we, as a glance at the records of our Patent Office will reveal. The South Americans like novelties and are willing to pay good prices for them, and it is surprising how prompt are the returns there awaiting American manufacturers. It is for the reasons just stated that 
our new exporters will find that in those markets we shall enjoy an advantage over our European competitors, instead of having to compete with them under heavy handicaps as we do in Europe and in the Far East. One may confidently recommend to a manufacturer desirous of entering the foreign trade that he first turn his attention to the South American market.

Nor will this South American trade benefit us alone; it is not one of those "jug-handled trades" with the handle only on one side. Not only will it benefit both sides for the usual commercial reasons, but also it will have an added and a special value for our Southern friends. We have become a great investing nation, and South America needs capital to develop her great resources, especially now that the terrible struggle across the ocean is rapidly destroying those amassed savings of Europe which used to seek investment abroad. Along with the increase of our trade in Latin America will come a greater knowledge by our bankers of the many opportunities there for safe and lucrative investments, which means that they will turn into that channel our surplus wealth, enriching both our Southern friends and ourselves. I venture to predict that the realization of the value of such investing possibilities will cause the Governments of those countries to redouble their efforts to protect foreign capital, because thus will they hasten the increase of those investments. 


\section{MODERNIZING THE MONROE DOCTRINE}

In the preceding chapter we have seen spread out by means of a few figures the map of the material importance of South American States. Such annual foreign trade totals as $\$ 1,000,000,000$ for Argentina, $\$ 500,000,000$ for Brazil, $\$ 200,000,000$ for Chile, and $\$ 100,000,000$ for Uruguay, not only prove how great is the purchasing power of South America, making their markets well worth our study, but also they show how that purchasing power is distributed. In those markets we have not in the past succeeded as we should have for a number of reasons.

One reason now in process of being satisfactorily rectified was that we used to lack banks. By that statement it is not meant that the ordinary facilities for transmitting money, etc., were not available, because that is not true, but there are on record a number of instances where Americans have been discouraged from undertaking perfectly sound business in Latin America because of the nature of the banking reports furnished them on the subject by English, German, or French banks. A certain contractor from our Middle West refrained from bidding on some work to be done by a great Argentine railway because of the discouraging report sent him upon that railway by an English bank in Buenos Aires. And yet this bank had more than one of its directors then serving on the board of that railway, and was therefore peculiarly well informed on the splendid financial condi- 
tion of the railroad, that it had over five thousand employees, and was abundantly able to pay for the contract upon which our contractor refrained from bidding because of the bank's report. Many instances of this sort could be cited, but this one is sufficient to show the handicap now being overcome by the initiative of the National City Bank and other great American institutions.

While we are on the subject of banks it is relevant to remark that Argentina has for a long time had in successful operation a "central bank," the Banco de la Nacion. In its "Caja de Conversion," as security for the value of Argentine paper currency, is the fourth largest gold reserve in the world, about $\$ 260,000,000$, only exceeded by the gold reserves of Russia, France, and the United States. The effect of this is, of course, that the value of the Argentine paper peso never fluctuates any more than does our paper money. A similar stability is likewise assured to the currency of Uruguay, something which unfortunately is not yet true in Brazil and Chile.

Another of our handicaps in the past was the fact that we were accustomed to send our best agents to Europe and the Far East, while comparatively few of our commercial representatives in South America were recruited from our trained salesmen. Here is a case in point. One day there called at my Legation in Buenos Aires a man with a sealed letter of intro- 
duction; the reason for its being sealed developed as I read it. It was from the vice-president of a large company in New York City, and it ran somewhat as follows:-

\section{“My dear Charlie:}

"We hasten to act upon the general information you wrote us through the State Department by sending down an agent who will present this letter of introduction. He is my wife's brother, and although he has failed in several businesses in New York, the opening seems so good in Buenos Aires that I am hopeful that he will succeed there."

There have been too many men of that type sent to South America, and it was a great mistake to treat that great field as a business scrap-heap. Of course, that man spoke no Spanish: it ought by this time to be unnecessary to recommend that all agents sent abroad speak the language of the country in which they are going to operate. What would be thought here of an Argentine coming to New York to get business and yet speaking no English? Fortunately for us, Spanish is easier to learn than any other foreign tongue.

A manufacturer who wishes to enter the foreigntrade field, but is unwilling or unable alone to go to the expense of an agent, sometimes unites with several others so that together they can send one man to represent them all. Is that worth while? - it all 
depends on what sort of products are thus represented by the one man. One of these joint agents told me in Buenos Aires that he had not met with much success, but the reason for his failure became clear when he added that he represented a cotton manufacturer, a farm-implement factory and a locomotive company.

Another case that came under my observation was a great success - the agent represented people who made fine stationery, another who sold playing-cards, and a third who was a cheap silversmith. See how this combination worked out in practice. The agent went into a large department store and offered his three lines of goods. They bought some of the stationery, but refused his other two offerings. In connection with filling the stationery order it was necessary for him to visit the store several times, which put him into such relations with it that before he left the city, they also gave him orders for all the other goods he represented. If he had represented the silversmith alone, he would probably have accepted the first refusal, and thus failed to get the order for silverware which his visits in connection with another line enabled him to get. The moral of this tale is that a joint agent can work effectively if all the goods he represents can be offered to the same purchaser.

While it is true that the South American asks for long credits, it is equally true that he has come to do that because those facilities have been offered him 
by European manufacturers as a proof of their confidence in his willingness and ability to pay. The manager of the excellent credit agency conducted in Buenos Aires by R. G. Dun \& Company publicly stated that on an average the credit of business men in that city was as good as that of the average business man in New York. Mr. Farquhar, honorary vice-president of the Chamber of Commerce of the United States, says that, although he has traded for many years with South America, he has never lost a dollar in bad debts.

Any one who travels in Argentina notices that the country is extremely flat. Although the city of Buenos Aires is one hundred and twenty-five miles from the ocean, the Rio de la Plata at that city is thirty miles broad, which shows that the country lacks such a fall of water as would provide waterpower. It also lacks coal. These two facts combine to make manufacturing very expensive, which ought to show American manufacturers that if they build up a line of trade in that country they are less apt to have the trade taken away from them later on by local factories than they are in China, where recently constructed plants are already underselling our steel rail and our cotton goods manufacturers. This fact makes for a stability of trade when it has once been secured.

The doorway to an increased and splendid foreign 


\section{SOUTH AMERICAN MARKETS}

trade with South America is blocked only by the Dragon of Inertia, but it seems highly unlikely that our well-known business initiative will long be kept from such opportunities as lie beyond that door by any such creature of mythological zoölogy. 


\section{CHAPTER III .}

CHAMBERS OF COMMERCE: THEIR OPPORTUNITY FOR PATRIOTIC SERVICE INTERNATIONALLY AS WELL AS NATIONALLY

IN this chapter let us consider what sort of organized equipment we have ready to our hand for entering this great Southern field, and also how that equipment can serve us patriotically as well as commercially. If the people of the United States, as people, and not as represented by their Government, can be aroused to the importance which the progress of Pan-Americanism has for them, this generation will go down in our national history as equally useful with the one which removed the drag of slavery from our forward march.

By the word "people" we mean the same political factor which the old town meetings used to embody, - meetings for the open discussion by citizens of matters of local interest, decided not by political alignment as upon national policies, but by a non-partisan consensus of opinion as to what was best for that community. We have almost forgotten what an admirably potent and democratic system we had evolved in those meetings, and have come to feel that all matters affecting the body politic must 
as a matter of course be handled through the great political parties. While it is true that we as a nation are committed to government by parties, and shall probably long continue so to be, nevertheless, that is no excuse for forgetting or discarding so valuable a system of political adjustment as, in its sphere, was provided by the old town meetings. I, for one, believe that the spirit behind that fine old system never has been discarded or forgotten, but that of late years it has been reincarnated, in even healthier shape, in the great chamber-of-commerce movement which has laid hold so strongly on our cities and towns.

Not only has there been a great increase in the number of such bodies, but also there has taken place a reorganization into quicker life of many already existing. In 1801 we had only four chambers of commerce, those in Boston, New Haven, New York, and Charleston. In 1858 we had but thirty, ten of them classed as chambers of commerce and twenty as boards of trade. We have now nearly four thousand, almost all of them more active and therefore more efficient than were the best of their prototypes a generation ago. This general improvement in numbers and quality has not been the result of any concerted movement, nor has it been directed from any centre, but it has come to pass as one of the natural and useful results of an increasing and insistent demand for efficiency which has arisen among us. 


\section{MODERNIZING THE MONROE DOCTRINE}

During the last two decades we have gone in for a thorough house-cleaning, not only in politics, but also in business methods, one of the outcomes of the new national spirit given us by the Spanish War, that great healer of sectional wounds and splendid inspiration for a stronger national patriotism. No longer was it enough to say that some institution existed because it used to exist; if good cause could not be shown for its existence, it had to conform to the new standards of public ethics and utility or go into the economic scrap-heap. Nor were chambers of commerce the only bodies subjected to these new tests of service, for the tendency ran all through our national life, evidencing itself in pure-food laws, pure-drug laws, etc., and a general overhauling of our governmental systems. Thanks to this general movement, not only were many chambers of commerce galvanized into a new and broader life and usefulness, but also combinations of old commercial bodies were effected in some of our larger cities like Chicago and Boston, where the more or less inactive units were merged into powerful and effective wholes.

We have reason to point with pride to the Association of Commerce in Chicago and the Chamber of Commerce in Boston as proofs of what can be effected to the advantage of a municipality by a union of existing groups of its business men along absolutely non-partisan lines. It is to be hoped that in Phila- 
delphia there will soon be crowned with success the laudable efforts of certain leading Philadelphians similarly to achieve a combination into a strong central body of her various existing commercial organizations.

In our Middle West it is commonly admitted that a comparison of the effectiveness, from time to time during the last twenty years, of the chambers of commerce in Pittsburg, Buffalo, Cleveland, Cincinnati, and Detroit, will reveal the cause for the differing growths of those cities during that period. The changes in the ranking of these cities by population have coincided to a surprising degree with the relative activities of each one's commercial organization. To any one who has had the opportunity to visit many of our chambers of commerce, it is surprising to find how far they have progressed from the old-fashioned dreary meetings held at long intervals, and to learn of the earnest way in which numerous subcommittees are now not only attacking old problems of local interest, but also reaching out for new activities that promise benefit to their community. And how is this work being done if not by virtue of a recall to life of the old local interest aroused by the famous town meetings of our ancestors?

It must be admitted that sometimes these commercial bodies indulge in mistaken or misplaced 
enthusiasm. This does not occur very often, but I remember addressing a certain Commercial Club in a State capital which was then chiefly concerning itself in turning one of the residential streets of its city into a shopping centre. How vastly better for that city if all its organized effort could have been directed toward seeking some new elements of benefit from outside instead of simply changing the location of certain shops already doing business in that city! What a different spirit was shown when the Chicago Association of Commerce struck out boldly along a new line by opening a building in Buenos Aires to display and sell the products of Chicago, an idea similar to one put in operation by the Manufacturers' Association of Chattanooga in their own city, with the difference that Chicago was not content to await the visits of buyers, but "carried the war into Africa" by moving their exhibits down to a rich market.

In connection with this revival of activity in commercial organizations, there has grown up a new profession, valuable now, but nothing like so valuable as it will grow to be. Each chamber of commerce needs a paid secretary, and in equipment for service these trained men must always keep ahead of the bodies with which they are connected. This fact makes for a profession of highly trained specialists in a new and constantly widening field, and right well 
are these men meeting the demands made upon their training and tact. They have formed themselves into the National Association of Commercial Organization Secretaries, and thus united form one of the most promising potentialities for national service that we possess. Each secretary in his own chamber of commerce is "the man behind the gun," the one man who is at headquarters all the time, to keep all matters constantly trued up, and to shape the details, something so necessary in all joint efforts, and especially necessary in volunteer commercial bodies always threatened with the danger that "everybody's business is nobody's business." It is difficult to see how a chamber of commerce with a poor secretary can prove very useful to its community, but, on the other hand, wherever you find a good secretary, there you are sure to see a fine chamber of commerce. Many of our universities and colleges are recognizing that this new profession has come to stay, and are offering courses of study to prepare young men for it. Although a comparatively new calling, the men now following it have already won the recognition and respect they deserve, and the future of the profession is bright with promise of usefulness.

In all local matters these improved and accelerated chambers of commerce have proved their great value beyond all question. Not only have they benefited their municipalities along the declared lines 
of their endeavor, but they have also materially improved the acquaintance between citizens working in a common cause, and by increasing the neighborhood spirit have perceptibly elevated the tone of the community. Thus they have brought back to us all the valuable things we used to draw from the old town meetings.

Great as is the proved value of these bodies in local affairs, and general as has been the recognition of this fact, it is only very recently that we have awakened to how valuable it would be to us as a nation, if these bodies could be banded together into a national body. Think of it, a combination of the best business brains working on problems of national import in the same manner that they have learned so successfully to do in local matters! And all this without the rancor which is always apt to prejudice a discussion of questions by political parties, necessarily desirous of governmental control. This nation-wide combination took the shape of a national body called the Chamber of Commerce of the United States. Although only three years old it has already secured, thanks to the skilful management of its first two Presidents Harry A. Wheeler, of Chicago, and John H. Fahey, of Boston, a membership of over seven hundred chambers of commerce, boards of trade, commercial clubs, and national trade associations, and about three thousand individual members. 


\section{CHAMBERS OF COMMERCE}

For the first time in our history the organized business men of our country have at their disposal a centralized force which will surely prove as valuable to them as labor unions have proved to workingmen. There is now provided an easy way for any city to ascertain how other cities with similar problems are meeting them. At last there is a clearing-house of new ideas and new methods wherever developed by enterprising secretaries or committeemen. Formerly one city might be proceeding along dull, oldfashioned lines, entirely ignorant of some novel and more efficient plans worked out by some other nearby city or cities. Plants and trees have their seeds spread broadcast by the winds, but there used to be no convenient way to spread new municipal ideas to other localities in need of them. Now there is no excuse for any chamber of commerce failing to have the opportunity to hear of and to try out what the best minds in the country have evolved for municipal betterment. All that is necessary is to apply for such information to the headquarters of the national chamber at Washington.

A most valuable service now being performed by this central body is that of the referendum vote it from time to time takes on questions of national interest. One of the most difficult of all tasks set a democracy is that of obtaining a carefully considered opinion upon a given question from the citizens of a 
given locality. The local newspapers are sure to entertain political prejudices, and when a political flavor has been introduced into a discussion, either at the polls, in the press, in a convention, or in smaller meetings, then we no longer have an unprejudiced discussion. At first glance an excellent field for such discussions would seem to be afforded by a congress of delegates from chambers of commerce, but even there we cannot obtain careful consideration of important matters, because there is not time enough for such deliberations. Manifestly, however, we are entering a hopeful field when we turn to these bodies of business men conducted on strictly non-partisan lines. Because there is not time enough at these conventions for the delegates thoroughly to sift out arguments and reach conclusions, it was thought wise to submit the subjects of discussion directly to the bodies represented by these delegates, let them, at such time and in such manner as best suits them, deliberately consider the questions, and when their conclusions thereon have been reached, return them to the central headquarters for compilation with other similar ones, and publication. Thus, for the first time, are we able to assemble the unprejudiced and deliberate business opinion of the country, and not only see clearly the country-wide trend of public opinion, but also what are its variations in different sections of the land. It would be difficult to overes- 
timate the importance to the conscientious legislator, either in the National Congress, or in the legislatures of the separate States, thus to learn how the represented really feel upon questions to be voted on by their representatives. The economic enlightenment to be derived from the national chamber's referendum on currency reform or merchant marine, for example, will surprise any one who reads the published report on the collated votes.

This national chamber, through its well equipped headquarters in Washington and its branch offices in other cities, is ready to answer questions concerning foreign trade, no matter whether asked by manufacturers already engaged in that trade, or by those just beginning to realize the desirability of securing a continuous outside market for their surplus products in good times, or for their ordinary output during periods of temporary depression at home. To this central body there can also apply similar foreign organizations, or individual merchants in other lands, and for this reason it seems one of the most promising agencies now active in promoting better acquaintance between the peoples of the Northern and Southern continents of our hemisphere. This leads us to consider the international possibilities of such national aggregations of business men.

In June, 1914, just before the European War broke out, $I$ attended in Paris an international congress of 
chambers of commerce which was the most impressive gathering of its kind ever seen. Its two thousand delegates, assembled from all parts of the world, not only greatly exceeded the six hundred similarly met together in Boston two years before, but also carried far greater weight than any earlier meeting of the sort, by reason of the increased strength as well as numbers of the different national delegations. Nothing political entered into its discussions, but business questions of great international moment were handled with a frankness, clearness, and force that governments would have been unable to show in like circumstances because they could not claim such a backing of solid business sentiment. No attempt was made to impose the will of the majority upon the minority, but public opinion necessarily grew more and more educated as the deliberations of such masters of business proceeded, and in the end the force of that educated public opinion was more effective for good than would have been the rulings of a majority vote. The delegates of no nation learned more from these conferences than did ours. If they had learned nothing else than the importance foreigners had long attached to their own national commercial bodies, it would have been well worth while, for it taught our men to appreciate the possibilities of our national chamber as they had not done before.

It became clear to any one following the sessions of 
that congress that if from now on the organized business men of the different countries could receive the power to declare war or maintain peace, now vested in political rulers, the horrors of war would never again so abruptly be cast upon nations as they have been in the past. Nothing promises better for the avoiding of future wars than the rapidly increasing strength of these commercial organizations that don't want war. War is bad business, and does not suit business men.

Business, be it local, national, or international, is greatly aided by better acquaintance and understanding between buyers and sellers. Pan-Americanism concerns itself with nothing else than better acquaintance and understanding between the peoples of this hemisphere. It is, therefore, clear why all friends of Pan-Americanism should and do contemplate with intense satisfaction the constantly growing power for good of organized business men, and are confident that as soon as those organizations fully realize their opportunities for patriotic service throughout this hemisphere a long step will have been taken toward the millennium in all the Americas. 


\section{CHAPTER IV}

LEGISLATIVE ASSISTANCE NEEDED BY THOSE ENTERING THE FOREIGN FIELD

The American business man is now seriously applying himself to the foreign-trade problem, and is using for its solution all the ingenuity and adaptability for which he is famous. But there are three very serious stumbling-blocks in his path to success - real obstacles that must be overcome, but which can be removed only by a power not possessed by any merchant or combination of merchants. The situation is serious and can be bettered only by applying legislative remedies. All over the country there is arising the cry: "Give new freedom to our railroads and our dying merchant marine so that they can aid our crusade for foreign trade, and permit American labor employers to combine abroad so as successfully to compete there against foreign combinations paying much lower wages."

So audible is this message in all parts of our land that if there be legislators who have not already heard at least some of its sound waves, then there must be something wrong with their political wireless-telegraph apparatus, or, to drop into archaic phrase, "they have n't got their ears to the ground." 


\section{LEGISLATIVE ASSISTANCE NEEDED}

This message comes from an aroused country which has recently become aware of certain entanglements that it wants removed. Rip Van Winkle has awakened from his long repose in the Catskills of home trade, but the first few attempts to stretch himself have revealed that clinging creepers have grown about his limbs. Those creepers will have to go, and if the sharpness of existing legislative wits are not sharp enough to cut them, others will be found to do it.

The country from which this message comes is no longer a country where the farmer sees no farther than his boundary fence, or the banker his local customers, or the merchant the home market alone. Not only have farmer, banker, and merchant alike become students of foreign trade, but advanced students - they know both what they want and also the handicaps that hamper them, and they want those handicaps removed. And this message of theirs was learned by the writer from nearly two hundred chambers of commerce all over the country. It is surprising how much there is for a man to learn when once he gets away from the localism of Manhattan Island, and comes into touch with that marvellous campaign for community-bettering now so vigorously carried on by the commercial bodies of our land. My message to them was of South America, the value of its friendship and of its trade opportunities, but their message to me was of far wider import, 
deserving the attention of us all and especially of those to whom we have delegated the making of our laws and the conduct of our government.

These chambers of commerce have now gotten far beyond their old discussions of the need for foreign markets as a field for the expansion of our manufacturing, or as a balance to offset any temporary contraction in home markets. They are away beyond that. The study of the railroad rebate evil and its correction led them to learn that those domestic rebates were but trifles in comparison with the rebates given foreigners by the foreign shipping conference combine in ocean freights, which annually transfer from our pockets to foreigners $\$ 600,000,000$ for freight, insurance, etc., not only bleeding us financially, but also leaving the foreigners with the possession of the ships, and with their factories protected against our competition.

Due credit should be given to William $\mathbf{R}$. Hearst for his patriotically persistent campaign through his many newspapers on behalf of our merchant marine, regardless of the risk of thereby losing the large advertising contracts in the gift of the German and English shipping companies that control ocean freight and passenger rates. If all our newspaper owners had been as patriotic in this regard as he, we should long ago have had legislation restoring to our flag its former glory on the high seas. 
Great as was the evil caused by railroad rebating, with all that it meant in discrimination favoring certain local shippers against other shippers, it was, even at its worst, only a pleasant joke in comparison with what the foreign shipping companies have been doing to our manufacturers. A Cincinnati man, who is an officer of a large manufacturing company there, asked for freight rates on machinery from New York City to Buenos Aires, and after the German steamship company had replied to his inquiry, they volunteered the statement that they would quote much lower rates from Hamburg to Buenos Aires if he bought the machinery in Germany, and would, besides, throw in the item of ocean insurance. A man who had a large concrete contract in Buenos Aires came to the United States at my suggestion, and through the National Association of Manufacturers made arrangements to pay a large sum of money to an American concrete firm to supply his needs. When he inquired about freight rates from an English shipping company's office in New York City, they answered his questions, and then they volunteered the statement that if he bought his concrete in England the rates from Southampton to Buenos Aires would be very materially less than from New York to Buenos Aires. A lawyer in Washington told me that when he returned from Rio de Janeiro to New York he came via Europe; that he paid thirty-nine pounds 


\section{MODERNIZING THE MONROE DOCTRINE}

for his ticket from Rio to Europe, but was told that if he would go from Europe to New York by an associated line, his ticket from Rio to Europe and then to New York would be forty pounds, or, in other words, only five dollars from Europe to New York.

Ten years ago if these statements had been made to a Western grain-grower or a Southern cottonplanter he would have replied: "I don't care, foreign ships are cheap ships, and I want my product carried cheaply." But now he knows better, he knows that when, as a result of secret rebates to foreigners, and of its so-called "fighting fleet," the foreign shipping conference combine drove independent vessels off the seas, the carrying rates for grain and cotton, which in 1910 were, respectively, .03 and .12, were "readjusted" by 1913 to .10 and .45 , respectively. He knows that the tribute he paid out of his profits to the foreign ships was trebled in three years, and that hurts! Therefore, and therefrom, he insists that our merchant marine be enabled to protect him from further extortion of that sort.

Nor have the leading men of the various communities who make up these chambers of commerce confined their study to American conditions, but have looked abroad and inquired into what other Governments were doing to obtain more foreign trade for their nationals; and what did they find? They soon 
came to learn that many useful things done across the water by Governments for the governed, are here forbidden by our laws. Chief among those governmental aids to enterprising exporters abroad is reduced railroad rates to the seaboard given for exports, and the encouragement for firms which are competitors in the home market to band together for foreign trade. Their competition at home keeps down the home prices, but once across their national frontier they fight only foreigners and combine to do so.

Now, with us a lower preferential rate on railroads for export articles is forbidden by the Interstate Commerce Act and the rulings of its Commission, while the Sherman Act interferes with combinations for foreign trade. All the foregoing is known to the organized activity of business men constituting these great commercial organizations. They have done everything possible to help themselves, but now they realize that governmental action is necessary to liberate our merchant marine from its present trammels, to release the over-regulated railroads from those regulations which prevent their assisting our exporters, and to free our producers to make such combinations in foreign fields as they like. Give us this new freedom for our foreign trade, and American brains and energy will soon get for American labor and capital what has been so long going to foreign labor and capital. 


\section{MODERNIZING THE MONROE DOCTRINE}

Of these three great and immediate reliefs now so widely and so earnestly desired by organized business men, the two mentioned last are the more easily obtained. Laws could speedily be enacted, one modifying the Interstate Commerce Act so as to permit railroads to grant preferential rates on goods to the seaboard intended for export, and the other amending the Sherman Act so that it shall be lawful to make combinations for trade outside our borders. As to the third point, - the assistance of our merchant marine, - it has been so much discussed that it has come to seem a difficult problem; but is it? Let us see.

The European War has temporarily frightened a number of shipowners into registering their ships under our flag, but when the war broke out we were carrying only eight per cent of our foreign trade in American ships and we had to pay any rates for the rest of it that the foreign shipping combine decided upon. We all want to get back to some such laws as were put on our statute books in 1789 by Washington, Madison, and Jefferson at a time when our ships carried but twenty-three per cent of our exports and imports, and which laws by $\mathbf{1 8 0 0}$ had already raised that percentage to eighty-nine per cent, and by 1810 to ninety-one and one-half per cent, at the same time giving us a merchant marine that won for us the War of 1812 . 
In 1828, when we were carrying eighty-nine per cent of our trade, the agricultural South and West combined against the shipping interests of New England and passed the Reciprocity Act of 1828, opening our trade to foreign competition, whereupon there at once began a loss which has now shrunk our total down to a paltry and shameful eight per cent. A Democratic Southern President, Polk, seeing the success of English subsidies in the then new steamship trade, followed their example and soon our success in steamships was rivalling our earlier success in clipper-built ships, but in 1856 the bitter sectional quarrel between South and North caused the Southerners in Congress, led by Jefferson Davis, to strike a blow at the shipbuilding North by repealing the mail subsidies. It succeeded. Thank God, that quarrel and its cause no longer exist.

To-day the cotton-growing South and the graingrowing West are as alive as the northeastern seaboard to the need for freeing our merchant marine from the meshes of the net that is strangling it.

Everybody wants our merchant marine assisted it was promised by all parties in the campaign of 1912. What happened after the election? The Democratic Party, in control of both branches of the Congress and of the Executive, enacted the tariff law of October 3, 1913, and in it put a section granting five per cent reduction in duties to goods carried in 
American bottoms. Sundry foreign Governments promptly filed protests with the State Department. These foreign Governments had long been planning to prevent any return by us to the laws which succeeded so brilliantly in the early days of our Republic. Thanks to certain Secretaries of State, more eager to perpetuate their names on treaties than to learn the history and policy of their department, those foreigners succeeded in weaving $a$ ? web of treaties which, in the opinion of the Attorney General of the United States (rendered October 31, 1913, to the Secretary of the Treasury), nullified all that part of the act which attempted to assist our merchant marine. And that was the end of it? No, it was only the end of that chapter, for the people of the United States waked up for the first time to the fact that constant vigilance must henceforth be given to what contracts our State Department makes with foreign Powers. We now insist on knowing if good bargains are being made for us, so flagrantly have many of our diplomatists been outwitted in the past, as witness this mesh of treaties that seem to leave us powerless to do what Washington, Madison, and Jefferson did in $\mathbf{1 7 8 9 .}$

But are we helpless, and are we outwitted? Let us look at these treaties, and see if anything could be added to the said opinion of our Attorney General. We shall find that almost without exception each of 
them contains a clause permitting either party at his pleasure, upon a specified notice generally of one year, to terminate it. No breach of treaty or of contract is necessary to terminate the treaties recited in the Attorney-General's opinion.

A notice of what we wanted would be sufficient, for such a request on our part would be so reasonable that every nation would consent to modify those treaties to meet our views. This suggestion of mine, made December 29, 1914, before the American Association for the Advancement of Science, brought forth predictions of direful results to us from foreign Governments if any such a general notice were ever served. And yet a few months later, under the terms, of the La Follette Shipping Law, just such a notice was actually served on all the Governments concerned in those very treaties, and the only harm we suffered was domestic, not foreign - the damage done both to our merchant marine and to the labor market of our seamen whose union representatives had urged the passage of the law.

To have served general notice that unless these treaties are so modified as to give us back the freedom of 1789 we intended availing ourselves of their abrogating clauses would have gained us respect from those very foreign chancelleries which to-day laugh openly over their success in catching our merchant marine in their net of treaties. It would be both 


\section{MODERNIZING THE MONROE DOCTRINE}

interesting and useful for us to learn which, if any, of those chancelleries would decline to make such modifications.

The Democratic Party loves to quote Jefferson, and all parties to quote Washington - very good, let them, once freed from our present plight, join in reenacting the laws which those two early statesmen put on our statute books. Fortunately, we are not here confronted with a question like that involved in the Panama Canal Treaty - in that treaty there was no abrogating clause, and we will live up to that bargain in which England got so much the better of us, cost what it may. England will some day come to see the expediency of modifying that treaty. We shall later on discuss if it be not the duty of our Government, the very next time England asks a favor, to exact, as a condition to granting it, that the HayPauncefote Treaty be so modified that we can do what we like with the canal built by our brains and our millions.

This message comes from no youthful debating societies, nor is it prefaced by the word "please"; it comes from thousands of men, full grown in their heads as in their bodies, business men who have organized to protect their rights and to get what they deserve, and who have come to know of certain impediments thereto which they properly expect to have removed by the Government which they them- 


\section{LEGISLATIVE ASSISTANCE NEEDED}

selves elected. No untried remedies are being sought - two of them have been successfully tested by the German Government, and the third by our own dear country under the guidance of Washington and Jefferson. Here is the message - but what will our Government do about it? 


\section{CHAPTER V}

THE SOUTH AMERICAN POINT OF VIEW: IS IT WORTH CONSIDERING?

IN this hemisphere the twentieth century will sooner or later come to be known as that of the Southerner. Already clear evidence is being shown of the steady, strong tendency which must, unless diverted or dissipated by some historical cataclysm, write this title across the century upon which we have entered. And any man concerned in public affairs who does not take into account the viewpoint of the Southerner has no claim to statesmanship, and does not deserve the confidence of his fellows. Nor is this true in our hemisphere alone, but also across the Atlantic as well, for who can fail to have observed the awakening of the Latin races of Europe? Was not the splendid new national spirit of France a significant proof of this movement? And what of the stream of money continually sent home to Italy by her industrious and economical toilers in the harvests and on the railways of both North and South America - toilers who generally return to their native land and add not only to its public wealth, but also to its worthy citizenship? More marvellous still are the amazing annual increases to be noted in the 


\section{THE SOUTH AMERICAN POINT OF VIEW}

already impressive foreign trade of Argentina and of Brazil.

In our own Southern States, are we not witnessing the working-out along practical lines of one of commerce's strangest fairy tales? Go to Birmingham or Atlanta or Chattanooga, or to any one of the long list of great modernized cities in the South, and the truth of this proposition will receive ocular demonstration of a surprising completeness. While engaged in addressing commercial organizations all over the country, the most instructing experience to me of all (and there were many) was the realization that nowhere is municipal collective effort, on the whole, better conceived and conducted, and yielding better results than in the South. All parts of the United States have come to recognize and to be proud of the New South, and of all it means to the strength of our nation: why are we so reluctant to give the same recognition to the great republics of South America?

Perhaps we will all agree that the intentions of our nation in its dealings with Latin-American countries have always been characterized with that high altruism which is the strength of the Monroe Doctrine in the hearts of the American people. We have always tried to conduct ourselves in a manner which we believed to be just and upright, and for the benefit of our Southern neighbors. But almost never have 
we taken into account the viewpoint of the South American, nor considered whether our actions pleased him or whether our suggestions were formulated in accordance with his views. It has been as if a man just leaving a restaurant after a hearty luncheon were invited by a friend to go back with him and eat another luncheon. The intentions of the friend would be very hospitable, but his hospitality would have failed to take into account the viewpoint of the guest he desired to please. In this respect Pan-Americanism has ushered in a new era, for at the very root of its splendid growth lies a consideration for the viewpoint of others.

It is a fine thing for the future of our hemisphere that the southern half are Latins and the northern Anglo-Saxons, because each of those two races has much that is complementary to the other, so that each can with advantage learn from the other and thus both secure a result more nearly perfect than either could alone have attained. But both the Latin and the Anglo-Saxon of the Western Hemisphere are very different from their original stock in the Eastern Hemisphere. It seems to me that our people are in many ways as Latin as our brothers to the south, especially in quickness of thought, liveliness of temperament, and that trait which they call "simpatía," a word for which there is no exact translation in our language. That our racial traits are dissimilar is a 


\section{THE SOUTH AMERICAN POINT OF VIEW}

distinct advantage, not a handicap. Is it not true that the mixture of races in the United States acts as a brake on our going to war with any nation having many of its children among us? This shows that even such a cloud as "hyphenated Americanism" has a silver lining, because those of English race here will always oppose an armed conflict between us and England, just as the German-Americans will want to avoid a war with Germany. From this conclusion it is easy to see that the very difference of our racial traits from those of the Latin Americans will prove an asset to Pan-Americanism in its effort to preserve peace for all the Americas with all the rest of the world.

The peoples of our hemisphere have been allowed to develop naturally in an atmosphere of liberty and of ample opportunity, amid surroundings that in Europe the trammels of an older civilization would have rendered either difficult or impossible. This very freedom of the Americas has worked strange and radical changes in the European races that have come to it and have becone Americanized by its influence. It has Americanized the Latin just as much as it has Americanized the Anglo-Saxon. It has quickened the mentality of the Anglo-Saxon of North America, and it has steadied and broadened the vitality and energy of the Latin of South America, and by those operations is insensibly bringing them nearer 


\section{MODERNIZING THE MONROE DOCTRINE}

together, much nearer together than are the Latins and the Anglo-Saxons in Europe. This process has been working simultaneously in both South and North America, until we have almost reached a point of Pan-American equilibrium.

If any one doubts this, let him ask himself if there is any question that the people of our country are more impetuous and more volatile politically than are the English or the French. In England or in France the political party conducting the Government can be thrown out of office at any time by a vote of lack of confidence. If this were true in the United States, political parties would succeed one another in control at Washington so rapidly as to make for instability of government.

On the other hand, South Americans are not the excitable and therefore unreliable people that some writers would have us believe them to be. They have fully as much common sense per capita as we have. An interesting ethnological parallel could be drawn between the change effected in an Irishman by moving him from Ireland to New York, and that in a Spanish emigrant before he leaves his old home and after he arrives in the subtly Americanizing surroundings of Buenos Aires. If it is not the new environment that works the transformation, what is it? - and if the same effect is produced at the two extremities of the New World, at points six thousand 


\section{THE SOUTH AMERICAN POINT OF VIEW}

miles apart, is it not fair to call that effect Pan-American? And is it not fair to consider the viewpoint of the Americanized Latin just as much as that of the Americanized Anglo-Saxon? $\mathrm{He}$ is just as much a child of liberty and opportunity as we, and just as worthy of consideration.

We hear much of the steadiness and self-control of the Anglo-Saxon, and of the importance that they lend to his opinions, but when I was in Buenos Aires I had an opportunity to observe the steadying effect of this process of Americanization upon people of Spanish and Italian blood. An anarchist exploded a bomb in the great Opera House in the midst of an audience of Americanized Latins. What happened? First, ask yourself what would have happened if a bomb had exploded in the Metropolitan Opera House in New York among us Anglo-Saxons. I fear that all of us who are honest-minded will reluctantly agree as to the probably unfortunate results. What happened in Buenos Aires? A remarkable scene, which is a glory to Argentine citizenship. No tumult, no undue excitement. The injured were removed while the orchestra played the national anthem. Announcement was made from the stage that the performance was discontinued, and the audience quietly"filed out. If you had been there, you would have been as proud of those people as I was; as proud of their poise, and of their reserve strength of character, and further- 
more, as respectful of their viewpoint as the most enthusiastic believer in the future of our hemisphere could wish. When I reflect upon that surprising scene, I ask myself, Why have we throughout all our history constantly disregarded the opinion of our Latin sister republics, and failed to take them into our councils? I know that they are thoroughly entitled to our confidence.

4 . During my residence in Buenos Aires I came into most agreeable relations with its great university and, furthermore, took part in an international congress of university students from ten American countries. Because of those experiences I feel especially qualified to say that the generation of South Americans now preparing to assume the responsibilities of citizenship are fully as well equipped and as patriotic as are the young men of our own country. Moreover, they possess ideals and a sense of responsibility which are, if anything, higher than those of the average university student among us.

The importance of higher education in South America cannot be overestimated, for in those countries it is the intellectuals who have more to say in government than any other class. It is the custom to permit young men of ability to obtain the highest offices in the gift of the State, and this fact has its obvious repercussion upon the university students. When addressing a college meeting in the United 


\section{THE SOUTH AMERICAN POINT OF VIEW}

States, one receives the impression that the audience is composed of young men who as yet have no definite purposes other than those connected with the academic life they are leading. In South America a different state of affairs exists. There, in place of an easy-going academic flavor to undergraduate life, we find the universities peopled with young men eagerly awaiting the completion of studies which will permit them to participate in the real work of their country, and meanwhile straining at the leash of academic preparation until the moment comes for the realities of life outside.

The University of Buenos Aires has seven thousand students, and nowhere is there to be found a betterequipped law school or medical school. One's point of view of South America would be sadly incomplete if it did not take into account the excellence of such universities and the effect which they have in preparing men for public life. Men coming from such training-schools can be trusted to guide their ships of state, and the future of their Governments is safe in their hands.

I believe and I affirm that we have almost always sought to be not only just in our dealings with those republics, but also have tried to do what we thought was best for them. But why have we so persistently, so ignorantly, so blunderingly disregarded their point of view, even carelessly neglected to study it? 


\section{MODERNIZING THE MONROE DOCTRINE}

Of course, there have been exceptions, and brilliant exceptions, too, to our rule of careless disregard. One of the earliest is Henry Clay. That great statesman and orator was the leader of the movement to cause our country to recognize the independence of the Spanish provinces of South America. Splendid as was his oratory on their behalf, it pales before his luminous appreciation of how worthy of sympathetic consideration were the South Americans. This appreciation of his was based on a studious examination of their civilization, as is proved by the remarkable series of speeches he delivered in the United States House of Representatives between December 3, 1817, and May 18, 1820, advocating the welcoming of our struggling sister republics to the brotherhood of sovereign nations. The best proof of how painstaking was his study of the subject is that nowhere else in any language can there to-day be found so instructive a description of the advanced social conditions and form of thought at that time existing in South America.

He pointed out that in the city of Buenos Aires alone there were more and better newspapers those great vehicles of public thought and education - than there were in all of Spain and Portugal put together. The high standard of journalism noted by Henry Clay has persisted until this day, and it may be confidently asserted that in no city of the 


\section{THE SOUTH AMERICAN POINT OF VIEW}

United States are there finer newspapers or those better adapted for furnishing a free discussion of public affairs than in that same city in which Henry Clay observed such striking evidence of high civilization a hundred years ago. Nowhere in the world have newspapers so great political power as throughout South America, and this fact is generally justified. The "Prensa" of Buenos Aires, even in peace times, has never less than two pages of cable news a day, while there is no paper in the United States with half that amount. In addition to conducting a large free dispensary, free music school, complete wireless plant, etc., it provides over three hundred other South American newspapers with cable news, which shows the far-reaching influence of this admirable newspaper founded by the late Dr. José C. Paz, and conducted by his son Ezequiel in strict accordance with the high traditions laid down by the father. This is not the only excellent newspaper of the city, for there are many others, including the "Nacion," faithful to the fine memories of its great editor Mitré, the active and distinctively modern "Argentina," the independent "Razon," the acute-minded "Diario," etc. Of those two great leaders of public thought, the universities and newspapers, we shall speak more in detail later on, when treating of political questions.

Another brilliant exception to our general rule of disregarding the point of view of South Americans 
was furnished by Elihu Root. It is a patriotic pleasure to testify to the profound impression created in all parts of South America, not only by the official character of his visit, but also and more particularly by the deep interest and careful study which he, as an individual, devoted to their viewpoint on international affairs. It is a matter of congratulation to all of his fellow countrymen that so completely did his sincerity gain the confidence of those whom he went so far to meet and to study, that nowhere was there to be found any misunderstanding of his purpose or any imputation of any but the highest motives therefor. While he was studying them, they were studying him, and the effect of such an exhibit of North American manhood as he afforded had, as was but natural, a deep effect upon so keenly and sensitively appreciative a people as those who own the continent to the south of us. Perhaps no statement of his was more warmly received than this: "So I come to you to say, let us know each other better, let us aid in the great work of advancing civilization, let us help each other to grow in wisdom and in spirit, as we have grown in wealth and prosperity."

What does this mean? What can it signify but that the altruistic and enlightened friendship of Henry Clay was by the action of Elihu Root, as Secretary of State of the United States, officially raised to that highest category of governmental action, the 


\section{THE SOUTH AMERICAN POINT OF VIEW}

public and solemn endorsement by a sovereign nation of the idea of mutual consideration, an idea which has showed out so admirably in the life and actions of both those great statesmen. What would it not mean to our national repute abroad if those two men personified, not exceptions to the rule of our attitude of mind toward Latin America, but an established custom in that regard! 


\section{CHAPTER VI}

OUR POINT OF VIEW MISUNDERSTOOD IN LATIN AMERICA： PAN-AMERICAN CONFERENCES CORRECT MISUNDERSTANDINGS

So regardless have we been of the South American viewpoint that it is only natural that they too should have fallen into error as to what our attitude really is toward them, but even then they have not been so greatly mistaken about us as we have about them. It is but natural that many of our people, hitherto lacking interest in our foreign affairs, should be ignorant of other lands, but it is both surprising and disheartening to find this same ignorance in such otherwise well-informed quarters as our leading periodicals. I have two cases in mind which are peculiarly discouraging. Within a few months one of our three best monthly magazines published an article by a Western college professor gravely discussing the peril to Argentina of its Chinese and Japanese immigration. If the professor or the publisher had read the Constitution and the immigration laws of Argentina he would have known that no such peril exists. Last October the editor of an old and important weekly published in New York City, a clever writer of editorials supporting our refusal to recognize Huerta 


\section{OUR POINT OF VIEW MISUNDERSTOOD}

while President de facto of Mexico, gave as one of his reasons that no other Powers had recognized Huerta; practically all the leading Powers had done so, and had done it promptly! These are but two examples chosen from many similar ones showing how much easier it is to write than it is to study. Is it any wonder that the readers of such writers are slow in learning about the world beyond our borders?

Most of the causes for the erroneous diagnoses of us and of our psychology made by the South Americans can easily be traced back to us. We have been to blame, and we might as well look the fact squarely in the face. The worst of it is that we have never seemed to realize in what ways we were, with seeming deliberation, going about to get ourselves misunderstood. We have already commented on the unfortunate type of men who have frequently been sent South as representatives of our business houses, men who, having failed everywhere else, were sent down to that El Dorado by way of giving them a last chance to prove useful. That sort of thing did us no good, especially when the keen-witted South American compared such agents with the carefully trained men sent there by our English and German competitors. It certainly did not gain us any admiration, and it would be strange if it did not earn us contempt. Nor has our Government been much better in this respect than our business houses, for 


\section{MODERNIZING THE MONROE DOCTRINE}

many of the diplomatic representatives sent there by our State Department have not measured up to the responsibilities or opportunities of their respective posts so well as have our diplomats in other parts of the world.

From time to time we as a nation have been hurt by either the sayings or the doings of our Presidents, for it must not be forgotten that great importance is attached in all Latin countries to anything proceeding from the Executive, so sure are they that he is careful to represent public opinion. It is difficult to say which in the past has the more greatly tended to set these sensitive-minded peoples against us, a President who strictly regarded the administrative sovereignty of their countries, but blustered so as to arouse suspicions of his intended actions, or a President who spoke them rhetorically fair, but interfered in the conduct of their Governments. Perhaps both are equally unfortunate, and certainly both had the same cause; namely, an unwillingness to give courteous consideration to the viewpoint of the foreigners to be affected by these official acts or utterances.

Let me cite an example of one of the many unfortunate misunderstandings of us and of our intentions which have been our own fault, either actively or passively. We have seen elsewhere that the leading daily newspapers of the Southern continent are admirably supplied with foreign news by cable, rather 


\section{OUR POINT OF VIEW MISUNDERSTOOD}

better on the average than are similar journals with us. Most of that news has been of European events, while unfortunately but little was printed about current happenings in the United States, and that little of an unpleasant sort, such as lynchings, the gruesome discoveries of our spasmodic attempts to "clean house," business defalcations, or political scandals. On the other hand, because of their language and lands of origin, it was but natural that their newspaper readers should be interested in the political news of Spain, Italy, Portugal, and France, and, because of trade relations, in the commercial news of England and Germany. It was equally natural that they should care but little to hear of our doings either economic, political, or commercial. It was our fault that nothing had ever been done to correct that state of affairs.

It came to my notice in Buenos Aires that the importance of correct news reaching that great press was recognized abroad, especially in Japan and Germany, for weekly bulletins of news favorable to the interests of the nationals of those two lands were regularly distributed throughout the Southern continent. How this service was conducted was never clearly stated. It seemed to me that it would be more effective if frankly conducted by some trade body, and this idea has taken definite shape, for since the 8th day of January, 1915, weekly bulletins 


\section{MODERNIZING THE MONROE DOCTRINE}

have been sent to over three hundred Latin-American newspapers by the Committee on Foreign Relations of the Chamber of Commerce of the United States. Its excellently equipped headquarters in Washington collects the current news showing the progress of our industries, important legislative events, the activities of our public charities, of how our people responded to the opportunity to aid suffering in Belgium, Poland, and Servia, etc. It is a privilege, as chairman of that committee, to help shape these weekly bulletins to suit the journalistic requirements of the press for which they are written, and there seems ground for hope that this news-service is doing and will do its part in setting us right before the eyes of our neighbors. It is a keen pleasure to record that in this effort for better feeling between races the journalists of the Southern countries are cordially coöperating. Perhaps this was only to be expected, for in matters of that sort they have a broader point of view, and are less likely to be local in spirit than are their colleagues among us.

And now, a word about manners, especially when dealing with Latins. New College, Oxford, and Winchester School, in the cathedral city of Hampshire, both founded by that eminent figure of the fourteenth century, William of Wykeham, display, oft-repeated throughout their delightful architecture, his motto, "Manners makyth man." This self-avowed secret of 


\section{OUR POINT OF VIEW MISUNDERSTOOD}

his amazing success by that distinguished architect, statesman, and churchman, twice Lord Chancellor of England, deserves to be studied by all who have to do with strangers. We Americans especially will do well to ponder this ancient motto, for as a nation we are as short in manners and tact as we are long in ingenuity and versatility. South Americans have good manners, and expect the same of those with whom they come into contact, and our relations with them would be better if in the past we had oftener remembered the "Manners makyth man" so familiar to Winchester boys and New College men.

Another easily overlooked factor making for friction is that of too many visits to them by ill-chosen groups of our professors or students. Although the citizens of the lands visited realize as clearly as we do that many of these "personally conducted" parties are nothing more or less than junkets, still, it irritates them to have foreigners coming to inspect them as beetles stuck on pins are inspected under a microscope. They don't want to be considered as exhibits for sociological research parties. A number of strong editorials on this subject have appeared in their leading newspapers, perhaps the strongest of all being one in the "Nacion" of Buenos Aires which called a halt on such pedagogical impertinence. To recall the old fable, it may be fun for the boys, but it is not for the frogs. In the beginning these scientific 
pilgrimages served a useful purpose, but they have been so overdone as to become offensive. Nor is the personnel of such parties apt to be so tactful as that of most of the chamber-of-commerce trips of a similar nature. In passing, it may be said that improvements are possible even in those business tours. When an individual from the United States goes on a business trip, he can generally be counted on so to conduct himself as to earn the results which he sets out to gain, but when individuals set out in groups, as representing some chamber of commerce or other organization of our country, they should remember that as such they are assuming a representative capacity, and patriotism demands that by their actions they represent the best side possible of our civilization. When this is borne in mind, excellent impressions are made, impressions that cannot fail to benefit us all.

I believe strongly that each of our Ambassadors and Ministers should do his best to increase our trade with the country to which he is accredited. I believe in this idea because the steps which he must take to acquaint himself with the market needs at his post cannot but bring him into sympathetic touch with many important citizens, most of whom he would never have met in any other way. It is sure greatly to strengthen his position (and therefore his efficiency) to have those foreigners thus learn of his purpose to benefit both countries concerned by increasing 


\section{OUR POINT OF VIEW MISUNDERSTOOD}

the exchange of commodities between them. Many people believe that Consuls alone should undertake these matters, but their belief is founded upon ignorance of the fact that a Consul does not come into direct touch with the Foreign Office, but must communicate with it through his Ambassador or Minister. Thus the latter has frequent opportunity to converse with governmental chiefs, while the Consul never has. It is difficult to understand why all our diplomatic representatives have not seen and grasped this double opportunity to serve their own country commercially and at the same time to gain for themselves a wide acquaintance at their posts. As I look back on my two highly interesting years in Argentina, it seems to me that a large proportion of my friends there were first met through my constant endeavor to increase the commercial relations between that land and ours. Those friendships are for me a much more valued memory than the increase of our trade in those two years with Argentina from $\$ 47,000,000$ annually, to $\$ 80,000,000$, although it was through my efforts for the latter that those friendships came about. Furthermore, the Argentine Government contracts for nearly $\$ 26,000,000$, to gain which for United States factories our Legation did its best, have proved of great value in acquainting Argentina with our manufacturing capabilities, and in teaching us of Argentina's great advance as a world-power. All of the many Argen- 


\section{MODERNIZING THE MONROE DOCTRINE}

tines with whom I talked on commercial matters heartily approved this practical crusade to bring the two peoples more closely together, and there were frequent proofs that it helped to eliminate many misunderstandings, some of ancient origin.

Another bogey that needs exorcising is the belief held by many intelligent Latin Americans that because "divide and conquer" has wide acceptance as an axiom of strategy, therefore we would oppose strengthening combinations among our sister republics, and would prefer that they remain as small as possible so as to facilitate our swallowing them in detail. This is a singularly silly bogey, and in our closing chapter there will be found a complete exorcism thereof in some suggested combination of existing republics, certain greatly to strengthen Latin America as a whole. So far from wanting weak neighbors, we need stronger ones to help insure the continued respect of the Monroe Doctrine by outsiders.

It is like opening a window and letting in fresh air, to turn to the consideration of the work done by the Spanish-speaking American to remedy all the foregoing. Perhaps no one man did more for the cause of better feeling between the northern and southern halves of our hemisphere than the Argentine President, Sarmiento, that ardent student of our educational systems, the friend and biographer of our beloved Lincoln. "Sarmiento, the School-Teacher 
President" - what a strong, sweet, significant title to leave behind for future generations to repeat and ponder. In his statesmanlike make-up he combined an altruistic friendship for us with a careful personal investigation of our civilization, and he paid us the high compliment of causing the official adoption by his Government of the secondary-school system of one of our States (Michigan). He realized that the organized education of a people is necessary for a sure and even national development, and that it is of a special value in a nation whose growth presupposes the rapid assimilation of alien immigration, which is as true of his land as it is of ours. In a spirit of friendship and a desire to learn only of the better side of a foreign nation, he perceived that our public education had grown up about this same problem of immigration, and so he came to visit us, not as a critic, but as a friend. Sarmiento felt that the best way both to cure and to make impossible international misunderstandings is for the different races to know one another better, and especially to learn more of the finer traits which every foreign nation possesses. It is ignorance of those finer qualities which leaves us free to criticise and to dwell upon the less agreeable traits of strangers. Peace to his ashes! So good a friend not only of ours, but also of his own land, richly deserves the splendid statue now being erected to his memory in Boston. Would that the world 


\section{MODERNIZING THE MONROE DOCTRINE}

possessed more such noble souls as his, so that the word "foreigner" might change its meaning and more . closely approximate "friend"!

Chief among the factors efficient in laying these ghosts of misunderstanding have been the meetings of the Pan-American Congresses, so nobly conceived and put into operation by James G. Blaine, while Secretary of State. None of our statesmen has ever shown a clearer vision than did he in this field, and the success of the policy he fathered is a noble monument to his prescience. In these congresses there are met together the best minds of a score of republics, - minds differing among themselves in national and personal traits, but at one in the purpose which calls them together, - a closer brotherhood of nations in the common interest of humanity. One of these congresses took place in Buenos Aires during my term of office there, and it is intensely gratifying to be able to testify that nothing could have been more admirable than the manner and the purpose of its deliberations. Those who predicted that such congresses would chiefly be remembered for pyrotechnical oratory were sadly disappointed, for they were eminently practical both in their conduct and their results. Those detractors of their efficiency for service did not understand the spirit that is sweeping upward and onward the American republics, and do not realize that our lofty ideals are always coupled with 


\section{OUR POINT OF VIEW MISUNDERSTOOD}

an insistent demand that practical steps be taken toward the realization of those ideals. We, better than any other people on earth, know that independence is not gained by fine phrases and fireworks. We are a new phenomenon in universal history, so that perhaps our cousins of the Old World sometimes fail to understand what a common struggle for independence in the new and open territory of the Americas has done for us in creating a demand for steps as practical and progressive as those of our ancestors who shed their blood for our liberty. In addition to the practical service performed by these conferences, they are of great value as tending to diminish the friction between nations which is always possible where there is but little acquaintance between their nationals. The friendships formed at these meetings between the leading statesmen of the different countries have done much to form a basis for general inter-republic understanding and harmony.

Another potent factor in overcoming that ignorance of one another which certainly made for mistrust has been the Pan-American Union, conducted as it is under the supervision of a board consisting of all the Latin-American Ambassadors and Ministers in Washington, with our Secretary of State as its chairman. Starting from small beginnings it has, thanks to the zeal of successive directors, grown to such a stature as to possess great strength in the cause it 


\section{MODERNIZING THE MONROE DOCTRINE}

was founded to champion. Housed in its magnificent white marble home in Washington, due largely to the far-seeing generosity of Andrew Carnegie, and with the best director-general in its history, the energetic John Barrett, the Pan-American Union is receiving a far wider publicity and therefore a much greater power for useful service than it has ever before enjoyed. It is difficult to overestimate the importance to its great international ideal of having a permanent centre to which at all times inquiries can be addressed with the certainty of receiving prompt and reasoned replies. As well attempt to conduct a telephone company without a telephone central, as to expect practical results from even so useful an ideal as Pan-Americanism without an adequately maintained establishment of a continuing character.

With the frequent meetings of Pan-American conferences, with the ever-increasing efficiency of the Pan-American Union, with our growing respect for the South American viewpoint, and with a new appreciation by South America of the advantages and responsibilities of the Monroe Doctrine, we may confidently hope that not only is the era of misunderstanding reaching an end, but also, and better still, that there are being established such enduring safeguards against future misunderstandings as cannot but hearten the most enthusiastic patriot of each and every one of our republics. 


\section{CHAPTER VII}

THE MONROE DOCTRINE AND THE CANNING MYTH

ON the 12th of December, 1826, George Canning, then Prime Minister of England, made the proud statement in the House of Commons: "I called the New World into existence to redress the balance of the Old." This striking sentence, pronounced as it was by one of the greatest figures which the English Parliamentary system ever produced, has received wide credence ever since, even our own writers admitting that his suggestions had much to do with the wording and promulgation of the Monroe Doctrine. In South America, their belief in his controlling part in the acquisition and preservation of their liberty has caused the erection of more than a few monuments to his memory. It is to the credit of those warm-hearted peoples that these testimonials to him were not affected by the frank admission of his boast, that he was actuated not by a love for liberty, but by his need for something new to support his foreign policy in European affairs.

The credit for the calling into existence of the New World belongs not to Canning, but to the splendid patriotism of those colonists who by means of many 
a pitched battle and arduous campaign drove out the Spanish, and even defeated an English army by the River Plate. Theirs is the glory of having alone and unaided gained for themselves the great boon of political independence. All hail, then, to San Martin, Bolivar, Sucre, and their glorious and victorious brothers-in-arms! We shall see that Canning was equally unentitled to the credit of guaranteeing their hard-won independence against the land-hunger of Europe, which has made of Africa a congerie of European dependencies; no, the credit belongs to the people of the United States who, through President Monroe's Message, that first clarion call of Pan-Americanism, cried to all the world, "Hands off! These are our sister republics of this, the hemisphere of freedom!"

It is our purpose to show from documents, some long forgotten, some recently published, that Canning himself knew that his boast was an empty one; that his remarks to Rush (American Minister in London) had little to do with framing the Monroe Doctrine; that it was Rush who, entirely without authority, suggested to Canning the coöperation of England with America (just as he had suggested it five years before to Castlereagh); that he, Canning, was surprised by the terms of Monroe's Message, was opposed to its guaranty of South American liberty as against Spain, and also to its forbidding Europe to plant colonies in this hemisphere. 
The chief reason for the credence generally accorded on this side of the ocean to Canning's claim is Rush's expressed belief that Canning's suggestions were largely responsible for the Monroe Doctrine. It was but natural that Rush should have come to believe this. He had two sisters married in England which gave him such an intimate appreciation of the English point of view as to lend perhaps too great a value to their coöperation with his own country. Furthermore, it was only human for him to attach undue importance to certain remarks of Canning's of which he would figure in history as the medium of communication to his own Government. He realized and reported the deep impression made in Europe by the policy announced by President Monroe, but we shall see how far Canning's private views coincided with Rush's beliefs.

Rush tells us that toward the end of August, 1823 (the Monroe Doctrine was not announced until December 2 of that year), after he had broached the subject to Canning of England's following our lead in recognizing the independence of the Spanish-American colonies (which we had already done in 1822), Canning sounded him as to whether there could be effected some public expression "intimating the joint disapprobation of Great Britain and the United States of any projects which might be cherished by any European Power, of a forcible enterprise for 


\section{MODERNIZING THE MONROE DOCTRINE}

reducing the [Spanish] colonies to a subjugation on the behalf or in the name of Spain; or the acquisition of any part of them to itself by cession or conquest." A similar proposition was made by.Canning to France October 9, 1823. It seems to have been entirely overlooked or forgotten that Canning, when interrogated in Parliament "whether the King of Spain would be allowed by this country to seek to recover his Transatlantic Colonies," contented himself with stating "that the mother country had the right to attempt to recover her Colonies, but that no foreign power had the right to make that attempt in her behalf." How quickly this was forgotten appears from the fact that shortly thereafter Canning, himself forgetting it, made his famous boast. The struggling colonies heard only of his boast and not of his willingness to return them to Spain from whom they had just won their independence. Also there has been generally overlooked Rush's report that on November 24, 1823, Canning expressed his belief that a monarchy would be the best form of government for the Spanish colonies - a true friend of struggling republics, indeed!

In many writers there may be noted a certain restlessness - a note of protest that so inspiring a triumph for liberty in our hemisphere as was the continued freedom of the Spanish colonies, should have to acknowledge a source no higher up the stream of international ethics than the scheming of a politi- 


\section{THE CANNING MYTH}

cian who openly claimed that he had created South American liberty to use it as a pawn in his game of European politics. Must we admit that the Monroe Doctrine had its rise in the whirlpool of European chicane, and only later joined the majestic stream of liberty whose fountain-head was the Declaration of Independence? Many have felt how glaringly incongruous it was that a cause so far removed from international altruism should have produced so glorious a result, but it seemed impossible to find anything from an English source to disprove Canning's words, although many indications were available to show clearly that President Monroe was but announcing a widely cherished policy of the American people, and not launching a doctrine either invented by himself or suggested to him by any one European or American statesman. All of these indications antedate Canning's suggestion to Rush. The "Diary" of John Quincy Adams, then Secretary of State, shows that on May 13, 1818, President Monroe propounded the following question at a cabinet meeting: "Whether the Ministers of the United States in Europe shall be instructed that the United States will not join in any project of interposition between Spain and the South Americans, which should not be to promote the complete independence of those provinces; and whether measures shall be taken to ascertain if this be the policy of the British Government, 
and if so to establish a concert with them for the support of this policy." When, as a result of Rush having introduced the subject, Castlereagh sounded him July 31, 1818, as to a coöperation with the United States in respect to a mediation between Spain and her colonies, Rush was already authorized to answer that we would not take part "except on the basis of the independence of the colonies ... a determination to which his Government had come on much deliberation." Note this, "on much deliberation," and also that this was a full five years before he heard the suggestion from Canning upon which the latter and his admirers based so much. Jefferson, in a letter of August 4, 1820, to William Short, says: "The day is not far distant when we may formally require a meridian of partition through the ocean which separates the two hemispheres, on the hither side of which no European gun shall ever be heard." No, there should never have been any misunderstanding, at least on this side of the water, as to how generally accepted was this policy of our people to maintain ours as a hemisphere of liberty, nor any ignorance of the fact that Monroe but enunciated an established policy instead of launching a new doctrine. It was but the natural outgrowth and development of Washington's famous declaration against entangling foreign alliances.

Notwithstanding how easy it has always been for 82 


\section{THE CANNING MYTH}

a student of American history to show that Canning did not suggest the terms of the Monroe Doctrine, it was not until very recently that anything appeared by way of new evidence, which could conclusively prove that Canning knew when he made his boast that it was not a true one. The discovery to the world of this new evidence adds another chapter to the romance of historical "finds," the unearthing of which is so delightful to the student seeking the reasons for great events. Let us accompany him into the erudite atmosphere of his library where lie piled the dusty tomes and unpublished letters that smugly keep their own counsel and their writers' secrets. By such assiduous delving into ancient records did Funck-Brentano learn from the Archives de la Bastille the real identity of the mysterious wearer of the iron mask about whom Alexandre Dumas wove so delightful a web of fiction. John Fiske tells us in his "American Revolution" that it was a similar quest among the old books in the library of the Strachey family at Sutton Court, in the County of Somerset, England, that brought to light the letter of General Charles Lee, written while in a British prison during the Revolutionary War, which, some eighty years after the event took place, proved him to have been a traitor. How rightly Washington relieved him from his command after his then inexplicable behavior which so nearly lost us the battle of Monmouth! Imposing is the array of ghosts 


\section{MODERNIZING THE MONROE DOCTRINE}

which have thus accusingly arisen from ancient documents to correct the history of events long misunderstood or incorrectly reported.

And from whose forgotten writings shall we best obtain unanswerable proof that Canning was not responsible for the Monroe Doctrine, and did not seek to guarantee the freedom of Spanish America? What source could be more convincing than his own letters to Bagot, English Minister to Russia, recently published by a member of the Bagot family? At last we can discard the dramatic statement of a politician made at a strategic moment to support his political purposes, and read the facts as privately written by him at the time to an intimate friend.

In an official letter dated at the Foreign Office, January 9, 1824, just after receiving news of Monroe's famous Message, he says to Bagot: "How far that part of the speech of the President, which relates to Spanish America may ... have been prompted by a knowledge of the sentiments of His Majesty's Government upon that subject, it is impossible to say." Speaking of the differences between those sentiments and this speech he goes on to say, "The first and most essential difference is that the Government of the United States have actually acknowledged the independence of the late Spanish Colonies, while His Majesty's Government continue . . . still to withhold such recognition. . . . If the Message of the President 


\section{THE CANNING MYTH}

is to be considered as objecting to an attempt to recover her dominions on the part of Spain herself, there is again as important a difference between his view of the subject and ours as perhaps it is possible to conceive." The "New World" which he later claimed to have created could have again become subject to Spain, if only he be first allowed to use it in "redressing the balance of the Old"! Continuing he says: "It is hardly necesary for me to add ... that the principle (if principle it may be called) which is brought forward in the President's Speech, prohibiting all further colonization on the Continents of America, is as new to this Government as to that of France." A frank and full statement that Canning would not oppose our sister republics losing their liberty to Spain, nor wished them closed in the future to European colonization! - could anything be further from the Monroe Doctrine! Their temporary liberty was only to suit his political policy, and then, so far as he cared, they could be turned back to Spain, or colonized as have been India, or Egypt, or Algiers, or Tripoli! At last the cat is out of the (letter) bag.

As to the long-believed theory that he and Rush (he as the originator and Rush as the transmitter) had contributed greatly to the preparing of the famous Doctrine, hear this excerpt from the same letter of Canning: "I lost no time in applying amicably to Mr. Rush for an explanation of that part of 
the President's Speech. Mr. Rush professed to be wholly unprovided with instructions on the subject. He says that he has not heard from his Government since the opening of Congress, nor even received officially a copy of the President's Speech." This was privately written in January, 1824, and in December, 1826, Canning had the effrontery to make the public statement in the House of Commons, "I called the New World into existence to redress the balance of the Old"! He outdid Little Jack Horner in that he not only shouted, "What a big boy am I," but also claimed the credit both for pulling out the plum and for baking the pudding. Why not carve on the base of his statues in South America, "He approved the return of Spanish rule. He preferred monarchies to republics in South America!"

His lack of interest for the continued freedom of the South Americans, either from a renewed Spanish rule, or from their colonization by some other European Power, makes it but natural that his first Minister accredited to those newly born republics, Lord Ponsonby, should entertain such an attitude of mind toward them as to write home in 1826, "No eye ever saw so odious a country as this Buenos Ayres. I will not trust myself to speak of it"; and on October $\mathbf{1 7}$ of the same year, to write even more disparagingly of the Brazilians in a letter which tells of "Mr. Canning's approbation of my conduct." 


\section{THE CANNING MYTH}

It is uplifting to be able to turn from such a viewpoint of the South Americans to the following, "We behold there the glorious spectacle of eighteen millions of people struggling to burst their chains and be free." So spoke Henry Clay, the man who had more to do with the recognition of the independence of those colonies, both in baking the pudding and in pulling out the plum, than did ever the boastful Canning. From 1816 on, both in Congress and outside, Henry Clay had never ceased his efforts. In the winter of 1821, long before Canning's suggestion to Rush, Clay secured the passage in Washington of the resolution that "the House of Representatives participate with the people of the United States in the deep interest which they feel for the Spanish provinces of South America, which are struggling to establish their liberty and independence, and that it will give its constitutional support to the President of the United States whenever he may deem it expedient to recognize the sovereignty and independence of any of the said provinces." In 1822, President Monroe published the formal recognition, which was the crown on Clay's long struggle.

Modern South Americans have forgotten the persistent and intelligently strenuous friendship of Henry Clay, so deceived have they been by constant reiterations of the Canning "Myth." Their forefathers loved him so well that more than once there were 


\section{MODERNIZING THE MONROE DOCTRINE}

read aloud at the head of their revolutionary armies portions of the speeches he was making in our Congress from 1816 to 1820 , urging the recognition of their independence. His altruistic efforts in their behalf and interest in their war for freedom find an echoing note in the touching friendship of Lafayette for our own people under similar circumstances. Henry Clay was actuated by no other motive than admiration for the struggles of a gallant people and a passionate yearning that their independence be once and for all time recognized by his own beloved land, which had by so short a time preceded them in entering the family of nations. Henry Clay was tainted with no wish to use their liberty as a pawn in the game of politics, nor was he willing to give them back to Spain, nor to allow European colonization later on to rob them of their hard-earned sovereignty!

Now that the dusty tomes of old correspondence have given up their secrets, we may at last cast away the belief that there was due to the play of intrigue in European Courts that great boon to South America of freedom forever from their intermeddling. No longer need the boast of a sharp-witted politician continue to enjoy the confidence of credulous peoples who knew only of what he publicly said, and not of what he privately wrote. Away with the long-credited myth that put the Monroe Doctrine out of step with the majestic onward march of republican free gov- 
ernment! The tree of American liberty becomes all the more symmetrical, since we learn that the Monroe Doctrine is one of its own branches, and not an alien growth grafted upon it. Let the policy announced in Monroe's Message fit into its proper place in the orderly sequence of benefits won for political liberty in this hemisphere by that immortal document, the Declaration of Independence, which in express terms acknowledged as its inspiration a Power immeasurably higher than politicians for whom political liberty is but a tool to use, and, when used, to discard.

One of the most patriotic of all national traits is the respect which the Chinese pay to their ancestors. As among them, so among us, may there always be those who, in Isaiah's phrase, will "show us former things," so that we may jealously guard for our forefathers the glory which they won for our nation in building the splendid temple of liberty, a pattern for all the peoples of the world to follow. 


\section{CHAPTER VIII}

THE MONROE DOCTRINE AND ITS MISINTERPRETATION ABROAD

"Self-PReservation is the first law of nature," and the Monroe Doctrine is but the American expression of that homely maxim.

The idea underlying that Doctrine did not originate with Monroe, but had been a basic fact of our nation ever since "the embattled farmers" of Concord fired "the shot that was heard round the world." Says John Bassett Moore, that eminent international lawyer, known and therefore trusted in all the Americas, "The Monroe Doctrine has in reality become a convenient title by which is denoted a principle that doubtless would have been wrought out if the Message of 1823 had never been written - the principle of the limitation of European power and influence in the Western Hemisphere."

In Washington's Farewell Address he pointed out that Europe had "a set of primary interests which to us have none, or a very remote relation," and he urged that we make no alliances with countries across the ocean. He also predicted that "the period is not far off when . . . belligerent nations, under the 


\section{MISINTERPRETATION ABROAD}

impossibility of making acquisitions upon us, will not lightly hazard giving us provocation."

President Jefferson in 1808, speaking of Cuba and Mexico, said, "We consider their interests and ours the same, and the object of both must be to exclude European influence from this hemisphere." Later, when consulted by President Monroe, Jefferson wrote, "Our first and fundamental maxim should be never to entangle ourselves in the broils of Europe; our second, never to suffer Europe to intermeddle with cis-Atlantic affairs." Secretary of State Seward Novemiber 6, 1865, protested against the French claiming authority in Mexico, because "that authority is in direct antagonism to the policy of this Government, and the principles on which it is founded." This protest was backed by an army of veteran troops, sent to the Mexican border for that purpose alone. Indeed, one might fill volumes with quotations from our early statesmen showing how unanimously this idea of a protective seclusion laid hold upon the imagination of those who took thought of our national affairs.

What is the Monroe Doctrine? It frequently happens that the latter part of many discussions are given over to settling just what is the subject being discussed. Do not let us fall into that error - let us turn to the documents. In President Monroe's Annual Message to Congress, December 2, 1823, there 


\section{MODERNIZING THE MONROE DOCTRINE}

are two long passages which together make up the Doctrine. Two portions of those long passages convey the sense of the whole. "The occasion has been judged proper for asserting as a principle in which the rights and interests of the United States are involved, that the American continents, by the free and independent condition which they have assumed and maintain, are henceforth not to be considered as subjects for future colonization by any European Powers." The other significant portion of the two passages is: "We owe it, therefore, to candor and to the amicable relations existing between the United States and these [European] Powers, to declare that we should consider any attempt on their part to extend their system to any portion of this hemisphere as dangerous to our peace and safety. With the existing colonies or dependencies of any European Power, we have not interfered and shall not interfere. But with the Governments who have declared their independence, and maintained it, and whose independence we have, on great consideration and on just principles, acknowledged, we could not view any interposition for the purpose of oppressing them, or controlling in any other manner their destiny, by any European Power, in any other light than a manifestation of an unfriendly disposition towards the United States.... It is impossible that the Allied Powers should extend their political system to any 
portion of either continent without endangering our peace and happiness; nor can any one believe that our southern brethren, if left to themselves, would adopt it of their own accord. It is equally impossible, therefore, that we should behold such interposition, in any form, with indifference."

While the second quotation is taken from that part of the Message which especially relates to the then present danger of action by the so-called Holy Alliance of European Powers, the first quotation is from the passage treating of the claim by the Russian Czar to exclude foreigners from all commercial or fishing rights in waters off the American coast between $51^{\circ}$ north latitude and the Bering Straits, a claim we were resisting on the ground that he had no settlement on that territory, and "that we should contest the right of Russia to any territorial establishment on this continent, and that we should assume distinctly the principle that the American continents are no longer subjects for any new European colonial establishments." 1 This claim was adjusted by treaty in 1824 .

That negotiations with Russia should have been one of the causes for precipitating Monroe's pronouncement is to-day peculiarly interesting because Russia is now the one Power in the whole world

1 John Quincy Adams, Secretary of State, to Baron Tuyl, Russian Minister, July 17, 1823. 


\section{MODERNIZING THE MONROE DOCTRINE}

whose national ambitions and probable development in no wise run counter to the peaceful progress of Pan-Americanism. Neither in commercial nor in territorial expansions do Russian aspirations in any way endanger the tranquillity present or future of the New World. Indeed, if one looks into that future thoughtfully, it seems more and more clear that there is every reason for seeking a closer friendship between Russia and all Pan-Americans. It should be the next great development of our foreign policy.

Returning to the pronouncement of Monroe, we find many ratifications of it throughout our history by Presidents and Secretaries of State as well as by other statesmen. Few developments of the Doctrine are recorded, and chief among these is President Grant's Message concerning Santo Domingo, May 28, 1870: "The Doctrine promulgated by President Monroe has been adhered to by all political parties, and I now deem it proper to assert the equally important principle that hereafter no territory in this continent shall be regarded as subject of transfer to a European Power." This extension of the Doctrine is highly significant, meaning as it does that if any American republic tries to sell to a European Power any territory, such a sale would concern us. And therefore, also, we should feel it our duty to prevent any European creditor of any of these republics from attempting to press for such a cession of land. Presi- 
dent Roosevelt announced in August, 1905, that "it must be understood that under no circumstances will the United States use the Monroe Doctrine as a cloak for territorial aggression." President Wilson went even further by saying at Mobile, October 27, 1913, "I want to take this occasion to say that the United States will never again seek one additional foot of territory by conquest."

Still another extension of the Doctrine is that act of our Senate embodied in the so-called "Lodge Amendment," which opposes the taking up by a foreign commercial company of territory which may be useful for its Government, or, in other words, a transaction by a foreign company which would be contrary to the sense of the Monroe Doctrine if conducted by the Government of which that company is a national. The Lodge Amendment will be fully treated in our chapter on the Pacific Ocean situation. ${ }^{1}$

Some few writers have urged that this great Doctrine of ours has never received ratification by Congress, our chief lawmaking body. But surely we have only to cite two out of many episodes to prove them in the wrong. Pursuant to President Madison's suggestion of January 3, 1811, Congress, realizing the possibility of England's purchasing from Spain what is now the western part of Florida, promptly passed a joint resolution saying: "That the United States,

'See chap. XII. 


\section{MODERNIZING THE MONROE DOCTRINE}

under the peculiar circumstances of the existing crisis, cannot, without serious inquietude, see any part of the said territory pass into the hands of any foreign Power, and that a due regard to their own safety compels them to provide under certain contingencies, for the temporary occupation of the said territory." All of which, translated into the geographical facts of to-day, would mean that if Denmark tried to transfer her Danish West Indian islands to Germany there would be a historical precedent provided by Congress for opposing it. In passing, it is said that when the Danish Landsthing, in October, 1902, defeated by one vote only the ratification of their treaty selling those islands to the United States, it was the result of German influence, and Stephen Bonsal, in his book on the Caribbean Sea, reports that the large docks owned by the Hamburg-American Line in those islands now give the Germans practical control of the principal port in the island of Curaçoa.

For another congressional confirmation of the Doctrine let us turn again to John Bassett Moore, who says: "It must, however, be conceded that the most important political result of the Venezuela incident [1895] was not the decision upon the territorial question, but the official adoption of the Monroe Doctrine by the Congress of the United States, and its explicit acceptance by the principal maritime Power of Europe." 
In this connection to quote from him again: "To its explicit acceptance by Great Britain and Germany, there may be added the declaration which was spread by unanimous consent upon the minutes of the Hague Conference, and which was permitted to be annexed to the signature of the American delegates to the convention for the peaceful adjustment of international disputes, that nothing therein contained should be so construed as to require the United States 'to depart from its traditional policy of not entering upon, interfering with, or entangling itself in the political questions or internal administration of any foreign state' or to relinquish 'its traditional attitude toward purely American questions." "

As bearing upon what may be Germany's attitude toward the Monroe Doctrine, it is of interest that the German Ambassador at Washington, Count Johann Heinrich von Bernstorff, during a speech in Philadelphia November 6, 1909, said: “Mr. Coolidge thinks the chief source of difficulty between Germany and the United States may be found in the Monroe Doctrine, in regard to which the Americans will hear of no argument or compromise and are prepared to maintain their position at any cost. We in Germany are well aware of these facts, but there is not the slightest intention on our part to get a territorial foothold in the Western Hemisphere." A few weeks 
later, on December 11, Herr von Schoen, the German Secretary for Foreign Affairs, speaking in Berlin of this very speech, stated: "I must also formally associate myself with Count von Bernstorff," who "undertook to destroy the spectre of a German colonial empire in South America." As showing that the Philadelphia speech met with the Kaiser's approval, it is significant that Count von Bernstorff was promptly decorated with the order of the Red Eagle, second class, a high distinction.

These references not only bring to a close our brief showing of what the Monroe Doctrine really is, but also, by the reference to its acceptance "by the principal maritime Power of Europe," brings us face to face with its earlier misinterpretation abroad.

At the beginning of President Cleveland's negotiations with England in 1895 over the disputed boundary between Venezuela and British Guiana, Lord Salisbury flatly said: "The Government of the United States is not entitled to affirm as a universal proposition, with reference to a number of independent States, for whose conduct it assumes no responsibility, that its interests are necessarily concerned in whatever may befall them, simply because they are situated in the Western Hemisphere." Lord Salisbury was wrong, because he misinterpreted the Monroe Doctrine, and before those negotiations were concluded, his Government received the correct inter- 


\section{MISINTERPRETATION ABROAD}

pretation of the Doctrine, greatly to the benefit of Venezuela as well as to the national prestige of the United States. President Cleveland's reply to Salisbury (contained in his Message to Congress) was that the Doctrine, "important to our peace and safety as a nation, and essential to our free institutions, ... . was intended to apply to every stage of our national life, and cannot become obsolete while our Republic endures." All honor to President Cleveland and to his able Secretary of State, Richard Olney!

Although misinterpretation of the Monroe Doctrine in Europe has ceased, in South America, and for an entirely different set of causes, it long persisted. Let us see what two distinguished Englishmen, Lord Cromer and Viscount Bryce, have to say on this subject. Recently, in November, 1915, Lord Cromer thus expressed in the London "Spectator" his opinion of the South American point of view: "They are inclined to resent the Monroe Doctrine, which they hold to involve a certain degree of patronage, and which, inasmuch as they are now quite capable of defending themselves, they regard as politically unnecessary in order to secure their independence."

In his "South America," Viscount Bryce writes: "For many years after the achievement by the Spanish colonies of their independence, a political tie between them and the United States was found in the declared intention of the latter to resist any attempt 
by European Powers either to overthrow republican government in any American State or to attempt annexation of its territory. So long as any such action was feared from Europe, the protection this promised was welcome, and the United States felt a corresponding interest in their clients. But circumstances alter cases. To-day, when apprehensions of the old kind have vanished, and when some of the South American States feel themselves already powerful, one is told that they have begun to regard the situation with different eyes. 'Since there are no longer rain-clouds coming up from the east, why should a friend, however well-intentioned, insist on holding an umbrella over us? We are quite able to do that for ourselves if necessary." "And again he writes: "As regards the United States, there is a balance between attraction and suspicion. The South Americans desire to be on good terms with her, and their wisest statesmen feel the value of her diplomatic action in trying to preserve peace between those of their republics whose smouldering enmities often threaten to burst into flame. More than once in recent years this value has been tested. On the other hand, as has already been observed, they are jealous of their own dignity, not at all disposed to be patronized, and quick to resent anything bordering on a threat, even when addressed not to themselves, but to some other republic." 
Our national lack of tact is chiefly to blame for the long-existing misinterpretation of the Monroe Doctrine in Latin America. Sometimes the fault for these misconceptions of our real purposes cannot be laid at our door - they will prove either to have been mere mistakes, or to have been concocted and launched by trade rivals or else by some well-meaning but narrow-minded soul unable to realize that international hard feeling hurts everybody. As an illustration, let us see how one of these mistakes did arise and develop, for thereby we shall learn how efficacious is frank discussion in correcting such errors.

Some years ago a distinguished Argentine, destined later to be the President of his country (but now, alas! gathered to his fathers), His Excellency, Dr. Roque Saenz Peña, pronounced the noble phrase, "America for humanity." Such Latin Americans as mistakenly believed that the Monroe Doctrine had some sinister meaning for the Southern continent, that "America for Americans" really meant "America for the North Americans" - such men seized upon this noble pronouncement "America for humanity" as a battle-cry hostile to the Monroe Doctrine. This fact is here cited because it was typical of the many misinterpretations of that altruistic Doctrine which never meant and never should mean the taking by the United States of a foot of Latin- 
American territory. This is but one of many similar . misunderstandings, the ghosts of which were wont to stalk abroad, but which fortunately proved ghosts easy to lay. This interpretation of "America for humanity" proved a boomerang to the detractors of Pan-Americanism, for it needed but an intelligent glance at it to confound them. Of course, it really was nothing more or less than a notice to all the world that, although Pan-Americanism calls for closer friendship among the American republics too long separated by language, lack of steamship lines, and general ignorance of each other, it in no wise means a slackening of the historic bonds of friendship and esteem between ourselves and the nations of the Old World.

Enemies of the Monroe Doctrine hailed this phrase as a criticism of the narrowness of the Doctrine's pronouncement of "America for the Americans." Do those people expect us to believe that Saenz Peña's "America for humanity" meant that American territory was not to be reserved for the American republics, but should be divided among humanity at large? Or could they think that he was opposed to closer ties of friendship between all of the American republics? Such suggestions are too unreasonable to appeal to any reasonable man.

I am very glad to record here that after my distinguished friend Dr. Saenz Peña had read a speech 


\section{MISINTERPRETATION ABROAD}

made by me to the delegates of the Fourth PanAmerican Congress, interpreting his great phrase in the manner just described, he expressed his warm approval thereof, and further said that he could not understand the misinterpretations sometimes attached to his statement.

This leads me to say that, before leaving home to go to Buenos Aires, many friends warned me that the Monroe Doctrine was a dangerous subject to touch upon in South America, and that it should be carefully avoided, because there it was distrusted, the weaker republics fearing it and the stronger ones resenting its officious and unnecessary protection. It seemed to me that just because this state of affairs existed, silence was not the way to cure it. There never has been any reason why the doctrine should there be either feared or resented, and friendly speech, not silence, seemed the only remedy for such erroneous impressions. Dr. Saenz Peña's approval of my defending his humanly broad pronouncement and resenting its being narrowed into a petty, indirect attack on the Monroe Doctrine alone provides proof that such errors should not go uncontradicted.

It is true that our Southern brethren have frequently been misled in regard to this basic tenet of our foreign policy. And does not such an incorrect state of mind deserve correction or explanation?

Whenever any one of our countrymen proves his 
disregard for foreign public opinion by saying that the Doctrine explains itself and is perfect as it is, ought he not to be answered, "Go and live long enough in one of the great republics of the South to learn their point of view, and then tell us if you are contented that our dear fatherland should continue to be misunderstood as a Monroe Doctrine policeman, a clumsy busybody with a Big Stick, when we know so differently, and can so easily rectify that misunderstanding?"

The tact of this generation of ours must repair the damage done by the lack of it in the past. How shall we set about it? 


\section{CHAPTER IX}

\section{A PAN-AMERICAN TRIANGLE FOR PEACE}

ITS BASE: PAN-AMERICAN JOINT MEDIATION TO PREVENT WARS IN THIS HEMISPHERE

How shall the Monroe Doctrine be modernized, so as best to serve the present and future conditions of this hemisphere? Now is the time to examine this interesting question, for which we have been preparing ourselves; we have travelled together to South America, have met their people, studied their markets, and gained respect for their point of view. We have looked about us at home and have taken stock of chambers of commerce and other equipment ready to our hand for international crusades. We have searched our diplomatic history and thereby refreshed our patriotism by a clearer view of the beginnings of our foreign policy and the corner-stone thereof, the Monroe Doctrine. We have recognized the need for broadening and modernizing that Doctrine so as not only to prevent in the future its misinterpretation of the past, but also to increase its usefulness as a guaranty of peace for all the Americas against all the outside world. We are now ready to look out into the future, and counsel together as to how to 
prepare for it by utilizing what we have just seen and read.

As I look out into that future it seems to me that I see looming up before us an imposing geometrical figure, sturdy as an Aztec pyramid, a monumental "Triangle for Peace," a Triangle drawing from PanAmericanism the strength of each of its sides and the defensive self-reliance of them all in combination. The proportions of this Triangle for Peace are so impressive that its base covers inter-republic harmony throughout all the Western Hemisphere, while its easterly side rises as a bulwark against frictional misunderstandings with Europe, and its westerly side assures a lasting peace on the Pacific Ocean. Nor does this vast Triangle reveal itself with shadowy outlines or as the ghostly geometrical projection of empty oratory. It is as definite in its drawing as the carefully figured plans of an architect, and like them must bear minutest scrutiny in advance before ever the Triangle is set up. It is a definite foreign policy to be accepted and followed out to its completion, or else it should be promptly discarded, and we content ourselves with waiting, even though waiting means drifting, and drifting gains the respect of no one. If we cannot agree upon a complete plan let us have none at all, for if the spoken word of a nation be not promptly translated into continuing, consistent and completed action, the word had best never be spoken. 
Opportunism belongs to politics and not to statesmanship. This Triangle for Peace may not please, but it can never be criticised as indefinite.

First, let us consider the base of this Triangle, and see if there can be achieved so complete an interrepublic harmony as to enable us all jointly to address ourselves to constructing both its easterly and westerly sides.

To prepare that base it was necessary to take into account the general condition of misunderstanding which used to exist in Latin America as to what was meant by the Monroe Doctrine, and also as to what were our intentions in regard thereto. Any one residing any length of time in those countries knew that the situation needed to be met frankly, that the Monroe Doctrine must be made both clear and modern to those peoples, and that such a progressive step would do vastly more to clear up both past and future misunderstanding than would our abandonment of the Doctrine, even if such an alternative were possible. Such a withdrawal of Monroe's words inevitably leads to the logical conclusion that we are willing that any part of the Americas may be turned into an Egypt, a Tripoli, an Algeria, or a Morocco! There seemed to be no reason why all misunderstanding should not be met with the same splendid directness that President Cleveland used in the Venezuela difficulty, or President McKinley in the Cuban affair, for 


\section{MODERNIZING THE MONROE DOCTRINE}

the misunderstanding of either the Monroe Doctrine or our intentions had no reason for existing.

There are friends of mine, dear friends of mine, sleeping beneath the waving grasses on a certain Cuban hillside, and there can be no misunderstanding as to whether or not they laid down their lives for anything else than the highest ideals of Pan-Americanism. "Greater love hath no man than this, that a man lay down his life for his friends." We should be far prouder of our withdrawal from Cuba, after our two interventions there, than of the most successful war that we ever waged, and I know that all of South America feels that those withdrawals brought more credit to our flag than any other acts in the history of our Republic.

The way to clear away all these fogs of doubt as to the Doctrine and our intentions was to accord such respect to the South American viewpoint of it and us as to break down the illogical barrier between Americanized Latin and Americanized Anglo-Saxon. It seemed to me that this could best be done as follows: Whenever inter-republic difficulties arose in this hemisphere, the United States should always invoke the coöperation of one or more of our sister republics so that we thus might benefit by getting their Latin point of view on the problem, something we Anglo-Saxons had never done. But how and when could such a plan be opportunely put into operation? 


\section{A PAN-AMERICAN TRLANGLE FOR PEACE}

Suddenly there arose a situation of great difficulty between ourselves and Mexico. Many of our people clamored for intervention with an armed force. Here was the South American problem in an acute form; - how could it be met? Could so grave a crisis be converted into an opportunity to better our relations with all Latin America? During these days of strained international relations I feel restrained by reasons of patriotism from treating any other phase of the Mexican question than that of the suggested armed intervention, although I agree with my South American friends as to the impropriety of foreign interference in any way with the sovereignty of a nation. We should have recognized Huerta as the de facto President of Mexico, as did the great European powers. To refuse recognition to any individual unless he meets with our approval is to exercise a form of selection which we ought not to exercise, least of all in the case of any American republic. It is, of course, the duty of every nation to defend the life and property of its nationals in foreign lands, but this should be done without upsetting the existing government of any such country.

The United States ought not to have intervened in Mexico. What should we have thought if any European Power had attempted armed intervention in our country during the Civil War? Some may argue that because the revolution in Mexico has lasted so long, 
we should therefore have intervened. Our Civil War lasted four years, but there never was a time that we would have tolerated intervention. Is there any reason why the Mexicans should not be left alone as we were? To this question some will answer that the parallel drawn is not a fair one, because, in the case of Mexico, if we did not intervene some European Power might take that step, which would contravene the Monroe Doctrine, that important and justly cherished principle of our foreign policy. But do not let us get into the habit of intervening; a study of history reveals that it is an easy habit to acquire. We have territory enough already, and I believe that all patriotic citizens of our great Republic should rather address themselves to the important problem of gaining the complete confidence of our neighbors to the south, which confidence I earnestly believe we are entitled to have.

I am an ardent advocate of the expansion of our foreign trade, but I am the kind of jingo that believes it is vastly more important for us, commercially as well as altruistically, to have the confidence of all our sister republics than the territory of any one of them. And let me say that the shortest route to obtaining our share of their great trade is by gaining the entire confidence of those splendid peoples.

We have concluded that the South American viewpoint richly deserves consideration, and because there 


\section{A PAN-AMERICAN TRIANGLE FOR PEACE}

had existed a misunderstanding touching the Monroe Doctrine, that therefore their viewpoint thereon especially merited our attention. The question, then, was, What really was the viewpoint of the Latin American upon the Monroe Doctrine, and how by frankly meeting it could we stop it from seeming to him unilateral and constabulary and make it PanAmerican in scope? The opportune time seemed to have come to launch this idea which forms the base of the Triangle for Peace.

Three years ago, on January 9, 1913, a day when my heart was deeply touched by receiving from the Argentine Minister a special gold medal sent me by the Argentine people, I ventured to formulate a suggestion, prompted by my knowledge of and love for our Americanized Latin brothers. It came as a result of my two years' stay in South America, with the facilities thereby afforded for studying the point of view not only of the people in their everyday life but also of the political and intellectual leaders of twenty republics gathered at several international conferences. This suggestion was, thanks to three powerful agencies (one Argentine and the others of New York), cabled to about three hundred LatinAmerican newspapers. It was as follows: "Let us see if this discussion of intervention in Mexico may not, perhaps, afford an opportunity to set us right upon the subject of the Monroe Doctrine in the eyes of all 


\section{MODERNIZING THE MONROE DOCTRINE}

Latin America, and at the same time provide a possible solution of the very question of intervention itself. Now, for my new suggestion: Suppose affairs should take so serious a turn in Mexico, or any other sister republic, that, either to forestall an armed intervention there by some European power seeking to defend its citizens or else to perform like service for some citizens of our own hemisphere, it finally becomes necessary under the terms of the Monroe Doctrine that the United States intervene, I would suggest that we invite Argentina and Brazil, or some other American country or countries, to join with us, just as Secretary Knox did in the case of the Peru-Ecuador misunderstanding, although in that affair there was no question of the famous Doctrine or of armed intervention. What would be the result of such an invitation? It would have two marked tendencies, both of which would be highly desirable: First, it would entirely remove any idea among our South American neighbors that our purpose was land-grabbing, because a man does not invite two neighbors to accompany him on an errand intended to benefit him alone. Secondly, and in my opinion of equal importance, it would free our Government from the persistent importunities of individuals and corporations urging our sole intervention to benefit their own pockets, but who would not favor a joint intervention by us along with other powers. Furthermore, it would be the 
best and most convincing form of invitation to Latin America to participate equally with us in the responsibilities and development of the Monroe Doctrine. The great Doctrine would at once become continental, and cease to be unilateral, which is to-day its one great defect. It is not the duty of the United States to police Latin America, and the sooner we get that idea spread broadcast, not only in South America but also in North America, the better will it be for our international repute. Whenever, under the terms of the Monroe Doctrine, an occasion for armed intervention in this hemisphere arises, let us, in each and every instance, invite participation in that responsibility from other American countries, all of which are equally concerned in the benefits and responsibilities of that Doctrine."

That is what I said three years ago, and since then events have strengthened me in the opinion then expressed. The chief value of this formulated plan for joint action by American Republics lay in the striking fact that none of the three hundred newspapers to which it was cabled disapproved it, and that almost all of them heartily endorsed it. This unusual unanimity on the part of the Latin-American press revealed that at last a note had been struck in thorough accord with the South American point of view, something we had too long disregarded. It is interesting to note that many of the United States news- 
paper comments on my suggestion were hostile, chiefly on the ground that the plan as outlined was not practical!

Fifteen months later, April 25, 1914, there was presented to the United States Government the following altogether admirable offer of just such friendly mediation in the Mexican difficulty by Argentina, Brazil, and Chile, through their diplomatic representatives in Washington:-

"With the purpose of subserving the interests of peace and civilization in our continent, and with the earnest desire to prevent any further bloodshed, to the prejudice of the cordiality and union which have always surrounded the relations of the Governments and peoples of America, we, the plenipotentiaries of Brazil, Argentina, and Chile, duly authorized thereto, have the honor to tender to Your Excellency's Government our good offices for the peaceful and friendly settlement of the conflict between the United States and Mexico.

"This offer puts in due form the suggestions which we had occasion to offer heretofore on the subject to the Secretary, to whom we renew the assurances of our highest and most distinguished consideration.

$$
\begin{aligned}
& \text { "D. da Gama, } \\
& \text { "R. S. Naón, } \\
& \text { "Eduardo Suarez Mujica." }
\end{aligned}
$$




\section{A PAN-AMERICAN TRIANGLE FOR PEACE}

It should be carefully noted that this mediation was for no other purpose than to prevent war between the United States and Mexico, and that no part of its purpose was to interfere in Mexican domestic strife. This must be borne in mind when considering in what measure it succeeded in its purpose.

This offer was promptly accepted by our Government. Here follows the note of acceptance sent by Mr. Bryan, then Secretary of State:

"The Government of the United States is deeply sensible of the friendliness, the good feeling, and the generous concern for the peace and welfare of America manifested in the joint note just received from Your Excellencies, tendering the good offices of your Governments to effect, if possible, a settlement of the present difficulties between the Government of the United States and those who now claim to represent our sister Republic of Mexico. Conscious of the purpose with which the proffer is made, this Government does not feel at liberty to decline it. Its own chief interest is in the peace of America, the cordial intercourse of her republics and their people, and the happiness and prosperity which can spring only out of frank, mutual understandings and the friendship which is created by common purpose. The generous offer of your Governments is therefore accepted. This Government hopes most earnestly that you may find those who speak for the several elements of the 


\section{MODERNIZING THE MONROE DOCTRINE}

Mexican people willing and ready to discuss terms of satisfactory, and therefore permanent, settlement. If you should find them willing, this Government will be glad to take up with you for discussion in the frankest and most conciliatory spirit any proposals that may be authoritatively formulated, and will hope that they may prove feasible and prophetic of a new day of mutual coöperation and confidence in America. This Government feels bound in candor to say that its diplomatic relations with Mexico being for the present severed, it is not possible for it to make sure of an uninterrupted opportunity to carry out the plan of intermediation which you propose. It is, of course, possible that some act of aggression on the part of those who control the military forces of Mexico might oblige the United States to act, to the upsetting of hopes of immediate peace; but this does not justify us in hesitating to accept your generous suggestion. We shall hope for the best results within a time brief enough to relieve our anxiety lest ill-considered hostile demonstrations should interrupt negotiations and disappoint our hopes of peace."

Five years ago - even so short a time as that - it used to be said in South America that the United States, the Big Brothers of the North, would never accept the assistance or advice of its smaller brothers of the South in regard to the settlement of interna- 
tional problems. Now the ghost of that misunderstanding has been laid. Here was just that assistance formally accepted and welcomed by us. No more striking evidence of sanity in the history of nations exists than this fine example of coöperation for interrepublic peace between the Northern and Southern nations of this hemisphere. It was a world-event of great importance, but it was an American event of paramount importance. Our acceptance of the proffered mediation has not only helped toward setting us right with the people of Mexico, but it has also brought home to all of South America the value of the Monroe Doctrine as an instrument for preventing the overflow into this hemisphere of the military spirit which is now devastating Europe.

Following this acceptance there were held at Niagara Falls, Canada (close to Buffalo), a series of PanAmerican sessions, beginning May 20 and lasting into July, which were attended by the three ambassadors who signed the offer, the representatives of the United States, and certain Mexican delegates. The deliberations of this conference were followed with the keenest interest by the general public. At the close of these sessions the Brazilian Ambassador, the senior of the three mediating diplomats, in a public statement to the press, used the following words: "It is a source of satisfaction to me to be able to say that one of the essential points of our programme - 


\section{MODERNFZING THE MONROE DOCTRINE}

that dealing with the international phase of the conflict - is practically settled. This does not imply that we go home with our task concluded, but we feel that so far we have averted war. We have established, also, through agreement between the parties most directly interested, and in complete harmony with the sentiments of the Government of the United States, that it is a principle of American policy to have our national problems always given a fair examination and settled without foreign interference. We understand that if such a result has been attained, we shall have created a more favorable atmosphere in international politics in America."

Perhaps before closing this chapter it would not be inappropriate to remark that there seems to be a limit beyond which such a mediation could serve no useful purpose. It is true that this A.B.C. mediation has given great impulsion to the doctrine of the complete sovereignty of each nation, be it large or small, something which hitherto Latin Americans have unreasoningly believed to be threatened by the Monroe Doctrine, but it is equally true that at the present development of international relations there should be a limit set to such proffers of mediation. Certain questions are so interwoven into the warp and woof of a nation's sovereignty - are believed to be so vital to its well-being and safety - as to make a real danger to its sovereignty of any offer of mediation therein by 


\section{A PAN-AMERICAN TRIANGLE FOR PEACE}

neutral Powers. Take, for example, the question of the jurisdiction of the River Plate, a matter so vital to both the nations bordering it, and at the same time so delicate as to make outside intermeddling both unwise and unpractical. On our side of the ocean we have taken a long stride forward toward finding a reliable safeguard for international peace, so long a stride and so practical a one that it would be a pity if further advances should be imperilled by unpractical suggestions from quarters not so well equipped in matters international as our South American friends have proved themselves to be.

We have seen how the base of the Triangle for Peace came to be laid. Let us next consider if success attended that effort, for if the base be not secure, the completing sides of the Triangle had best never be projected. 


\section{CHAPTER X}

WAS THE A.B.C. MEDIATION A SUCCESS?

AT such a crisis in the world's history as that through which we have been passing, there arose a crying need for some practical plan to further the somewhat disheartened crusade for international peace. But it must be practical, demonstrably and convincingly practical, because a general impression has got abroad that our peace societies are impractical - probably because their efforts have been handicapped by certain impractical folk whose stock in trade is talk and whose motives are tainted by a fondness for seeing their names in print. Besides, notwithstanding their efforts, wars have increased in frequency rather than disappeared.

A peace plan of just such practical nature has been both initiated and matured on our side of the ocean, a plan that did succeed in averting a war, whilst in the Old World a.whole continent is plunged into a dreadful maelstrom of armed strife from which it will take years to recover. This plan we have seen took shape in what is generally known as the A.B.C. mediation. Its great value is even yet not fully appreciated. Those living at the time of some great international change are generally unable to sense its importance 
- they are so close to the trees that they cannot see the forest. What reasons have we for believing that the plan proved a success?

The two most outstanding results of this mediation in the Mexican crisis are, first, that a High Court of Public Opinion has been established for the Western Hemisphere; and, second, that the Monroe Doctrine suddenly became continental and is no longer, even in the opinion of Latin America, unilateral and constabulary. The bogey of the Big Brother and his Big Stick has been proved to be nothing but a bogey! For the first time in the political life of the New World we have seen appear a High Court of Public Opinion, appealing so equally to Latin Americans and AngloSaxon Americans as to secure for its conclusions a respectful acceptance both in North and South America, an acceptance far harder for any one country to disregard than even the formal decisions of the Hague Tribunal. Indeed, in many ways it is the most practical result of that praiseworthy machinery for international peace which the successive meetings at The Hague devised and fostered.

We call it a High Court of Public Opinion; and why not? Who will gainsay such a title? Did it not consider in formal, patient, and decorous fashion the various sides of a vexed question, and was not the result of its effort the averting of a war, - a war wholly unnecessary, and yet, save for this mediation, 
dangerously imminent because affronts to national dignity were in the air, affronts which no nation could brook?

A court must be respected to be influential, and of international courts this is especially true, lacking as they do the police powers enjoyed by a court whose jurisdiction is limited to its own nationals. A court must have gained the endorsement of public opinion to be really effective, and the one we are discussing is a tribunal which possessed that endorsement for the excellent reason that it was the product of that very public opinion. If the public opinion of Argentina, Brazil, and Chile had not already been educated up to approving this offer of mediation, it would never have been made, but, thus approved, it carried with it so great a prestige as to insure the acceptance of the mediators' conclusions by Mexico, another Latin-American country, an acceptance which nothing fathered by an Anglo-Saxon country could have achieved.

It will take a little time for the people of the United States to realize how powerful an agency for international good such a tribunal as this may become in the Western Hemisphere, because we as a people do not yet know how much more powerful is public opinion in South America than among us. That it is so powerful is due to several reasons. One of them and a most important reason - was sensed by Henry 
Clay when, as we have seen, during his campaign in Congress for the recognition of the independence of the struggling Spanish colonies, he pointed out the amazing excellence of their press. Those high journalistic traditions have been worthily maintained, and it is difficult to overestimate the educational influence of good newspapers upon the public opinion of people so devoted to their perusal as are the South Americans. In view of our ignorance upon this point, it is necessary to emphasize how much more the leading journals of that continent turn the attention of their readers to international affairs than do ours. One of them "La Prensa," of Buenos Aires, with its two whole pages daily of cabled news sets a standard which none of our papers has yet reached. This amount of foreign news spread daily under the eyes of the South American, sets him thinking on international subjects, and keeps him thinking thereon day by day. It is no wonder, then, that the average man among them is more given to considering foreign affairs than are men of the same type among us.

Nor is it by newspaper-reading alone that our friends to the south of us have become so generally enlightened upon international questions as to be able to produce so sensible, so practical a solution of a difficult problem affecting two nations as this mediation has proved to be. Their great universities have long devoted more attention to international law than 


\section{MODERNIZING THE MONROE DOCTRINE}

have ours, and have interested in that subject many leaders of their bar, men of the type which in our country would be drawn rather to advising upon large internal affairs. Take, for example, the University of Buenos Aires. It is astonishing to foreigners to learn how long is the line of famous international lawyers trained by the law department of that one university. Two of them, Calvo and Drago, lend their names to two well-known doctrines of that great science, but there are many others - Merou, Zeballos, Montes de Oca, Piñero, etc.

Because of the popularizing by South American universities of international law as a study, their educated men come much better equipped than we do to the task of treating a legal question involving two or more nations. This should not surprise us, because such questions have for years enjoyed the attention of a greater proportion of their leaders in thought than has been the case in the United States.

Not only is South American manhood far better equipped for treating international problems than is generally realized in the United States, but also their manhood possesses a mental vigor about which we are but illy informed. We generally think of them as tropical races, handicapped by a tropical climate that is a mistake. Let me give one example of their capacity from many that $I$ know. There is a gentleman in Buenos Aires who is not only a leading member 


\section{WAS THE A.B.C. MEDIATION A SUCCESS?}

of Congress, but at the same time conducts a large law practice, is an active member of the law faculty of the university, and edits a law review which has a large circulation abroad as well as at home. Nor is the wide range of his activities regarded as in any way unusual in that community.

To one who likes these people, and who knows the education in internationalism which they have long been receiving from their universities and their press, it is not difficult to understand either that so practical a step as the A.B.C. mediation should have been evolved by them or that the corollary is true; namely, that the utmost public respect would be accorded throughout Latin America to a tribunal erected in such a manner.

As a preface to speaking of the second great result of this A.B.C. mediation, and also as a constant reader of that South American press whose influence we have seen is so great, it has been both delightful and significant to note the wide appreciation by those journals of our action in accepting this proffered mediation and in waiving any indemnity for the cost of our military occupation of Vera Cruz. This appreciation is delightful, because it shows a changed attitude of Latin-American public opinion toward us, and it is significant, because it indicates a brotherly tendency to understand the altruistic undercurrent of our national spirit. Our hearty acceptance of the mediation 
has done more to convince South America of our total lack of any desire to annex territory than did our successive withdrawals from Cuba after intervention there. They are more convinced now of the integrity of our purposes than they were even by two other recent and splendid proofs thereof; namely, our defense of Venezuelan territory in 1895, and our action in being the only nation to return to China a large portion of the Boxer indemnity.

And now for this second great result of the A.B.C. mediation, which is nothing more or less than the assumption by South America of her share in the responsibilities and development of the Monroe Doctrine. This alone would have proved the mediation a success even if no other good had come of it. In that regard surely no development more important than this mediation has taken place since President Monroe sent his famous Message to Congress on December 2, 1823. The action of the three mediating republics was approved by the sixteen others through the unanimous resolution of their diplomatic representatives, sitting together May 6, 1914, in the Governing Board of the Pan-American Union, that “it applauds and supports the mediation offered by the Governments of Argentina, Brazil, and Chile through the mediums of their distinguished representatives for the preservation of the peace of the American continent." 


\section{WAS THE A.B.C. MEDIATION A SUCCESS?}

At last South America realizes the altruism of our point of view in regard to that essential feature of our foreign policy, and at last our people have come to appreciate the immense practical value of South American public opinion in questions affecting the welfare of nations in our hemisphere. And how else than by means of this mediation could this splendid two-sided realization have come to pass so promptly?

Every once in a while we read of some blood-thirsty philosopher sitting quietly by his peaceful fireside in dressing-gown and slippers, and truculently announcing that wars will never cease, that our turn will come soon, and that we will fight South America. But why? especially now that we have in operation the "joint mediation" machinery of proved efficiency. If any sane man will stop for a moment and try to figure out what possible gain, either political, economical, or territorial, any Latin-American nation could hope to obtain through declaring war on the United States, or what the United States could hope to gain through declaring war on any Latin-American country, I think he will be able to satisfy himself that no such war is likely to take place. Even to put it on so sordid a basis as the commercial advantage to be enjoyed from continued Pan-American peace, is to prove the certainty that that peace will continue. The people of the United States have too much common sense not to realize that they would be kicking 


\section{MODERNIZING THE MONROE DOCTRINE}

over a valuably loaded apple cart if they attempted to acquire South American territory, an act which would so alienate the good-will of all the South Americans as very materially to handicap our now increasing trade with them.

It is nearly five years now since the importance of joint action by Pan-American countries in settling Pan-American difficulties began to be discussed in Buenos Aires. The idea was well received there, particularly by its ablest journalists, and especially by the remarkable mind of Dr. Davila, the talented editor of "La Prensa." To talk at any length with him was an inspiration to crusade for the idea, and it was my privilege later to urge some such joint action all over our country. A most inspiring ideal it was, but what a long and weary struggle seemed ahead before the consummation so "devoutly to be wished"! And yet it swiftly came true, a beautiful and splendid fact, a precedent to be followed, a standard set up which shall restrain any but forward steps in the future. In January, 1913, a couple of days after my formulation of the plan of joint mediation, in response to an inquiry from a friend as to how long $I$ thought it would take so Utopian a plan to gain the assent of practical men, I admitted that it would probably take many years, but that I hoped to train up my little son, then five, to devote his life to the crusade. It was an accomplished fact before he left the nursery. In 


\section{WAS THE A.B.C. MEDIATION A SUCCESS?}

less than two years and a half it has become a recognized method of adjusting international questions in this hemisphere.

It is hard to say which was the more difficult to effect - to convince South America that the Monroe Doctrine did not mean territorial acquisition by us, or to bring home to our people the practical value in international affairs of South America's friendly offices. But both these seemingly unattainable results have been achieved, and by this one act of South American mediation, offered in a spirit of practical international arbitration, and accepted in an equally admirable spirit of national good faith. Too high praise cannot be given to the diplomatic representatives at Washington of Argentina, Brazil, and Chile - Dr. Naón, Dr. da Gama, and Dr. Suarez - for their admirable part in this mediation, so admirable as to excite the highest encomiums on every side and to gain for them justly merited action by our Congress and recognition by our universities. The millennium is not here yet, and we should at present content ourselves with seeking only such steps to adjust or arbitrate international misunderstandings as are incontestably practical. Let us be practical, as practical as the South Americans have shown themselves to be by their A.B.C. mediation offer.

So successful and admirable has been the result of the A.B.C. idea on our side of the ocean as to make 
it seem unfortunate that it could not have been followed in Europe. Suppose, for example, that following on in alphabetical sequence they could have had in Europe an E.F.G. agreement between England, France, and Germany, - there would, of course, have been no European War! Furthermore, it is clear that the peace which follows this European War will not be a lasting one unless it promptly develops some such method for settling disputes.

Thanks to the successful operation of the A.B.C. mediation in regard to the Mexican affair, we of the New World have developed, even more than we can now realize it, a common form of political expression reaching from the Great Lakes to the Antarctic Ocean, which is nothing more or less than the realization of how helpful Pan-American conferences can be when there arise perilous questions of great import to us all.

The reason why Mexico accepted the A.B.C. mediation offer was because it came from certain sister republics speaking her own language, sharing her viewpoint, and following mental processes which she knew to be similar to her own. It is safe to say that if exactly the same proposition, which was made to Mexico by Argentina, Brazil, and Chile, had been offered by us, she would have rejected it because of her perfectly natural belief in an irreconcilable difference between the Latin and the Anglo-Saxon points of view upon such an international misunderstanding. 
Both South and North America now see that, as a result of this successful mediation, through intelligent coöperation between American Anglo-Saxons and American Latins, a great international danger was averted. And therefore all of us naturally ask why every such danger should not, in the future, be averted in a similar manner. It was such a long step in advance of the ancient and decrepit "one nation and one only" idea as to be really epoch-making. It has now become plain that it is perfectly feasible for all the peoples of this hemisphere to act jointly for the common weal upon almost any international problem.

Even those critics who have alleged, in the vernacular, that for decades Pan-Americanism was mostly hot air, must realize that now that hot air has become steam power. We, its friends, must not forget that steam must be utilized, because if pent up it becomes dangerous, and if freed, goes off in vapor!

We stall consider in the succeeding chapters how this new equipment born of this important event, this common form of political expression, may be utilized to guarantee us peace against dangers that might arise from without this hemisphere. Before the success of the A.B.C. mediation there could hardly even have been discussed the possibility of using such joint action against dangers from across the ocean, but now that a system of mediatory coöperation has been 
reached among us, we are able, for the first time, jointly to address ourselves to other problems arising from dangers which may confront us from outside and to coöperate in our defense against them. In this new field our Latin-American brothers have led the way by their joint suggestion to us of December, 1914, that we unite in a representation to the warring European Powers, favoring the neutralization of the waters of the Western Hemisphere. Such a suggestion would have been inconceivable before the success of the A.B.C. mediation, because of mutual distrust and the inability of either Latin or Anglo-Saxon to understand the other's point of view. But are there not further steps to be taken in that direction? - steps of the utmost advantage to the common weal of all Pan-American countries, and is not now the psychological moment to take them?

The base of the Triangle for Peace has been securely laid, so we may properly proceed to consider the erection thereon of an easterly side that shall serve as a bulwark against frictional misunderstandings with Europe. 


\section{CHAPTER XI}

\section{A PAN-AMERICAN TRIANGLE FOR PEACE}

ITS EASTERLY SIDE: A COMPLETED MONROE DOCTRINE TO PREVENT FRICTION WITH EUROPE

Is the life of a nation, just as in that of an individual, there may come an opportunity so obviously one for useful service as to make of the opportunity a pressing duty. I believe that such an opportunity is now ours by reason of Europe's wish for vast credits and loans from our country. I believe that because of this unprecedented state of international affairs, we can now perform such a service for Pan-Americanism as has never been possible since Monroe pronounced his famous warning to Europe, and which may never be possible again. Let us give a glance backward before looking forward, and consider for a moment the condition in which Pan-Americanism finds itself today, and the path by which it has advanced. For us of the most northerly republic, Pan-Americanism has always been linked with the Monroe Doctrine, which Doctrine is not only an important international fact, but also one founded upon a great principle. If it were not, it could never so completely have won the heart of our people as to make it one of the landmarks of our foreign policy. No nation's history re- 


\section{MODERNIZING THE MONROE DOCTRINE}

veals a policy which, while inuring to its own benefit, is at the same time so idealistically altruistic. It yields us no territory of any of our fellow republics of this hemisphere, but it opposes any such territory falling into the hands of any European Power, and thus tends to keep us free from the whirlpool of European politics.

We must not forget that Monroe's Message was but a logical corollary to Washington's oft-quoted recommendation against entangling foreign alliances. It was a corollary because, while we renounce any direct acceptance of such alliances, nevertheless, indirectly we might become embroiled by the planting in our hemisphere of European colonies, and it was this danger which Monroe sought to avoid. "We shall not cross the ocean to mix in your affairs, and you must not cross the ocean to mix in Western affairs," say we. And how has this policy of defensive seclusion worked out and developed? The next logical step, after the general recognition across the ocean of the Monroe Doctrine, was that our fellow American republics should come to agree that the Monroe Doctrine ought to be a continental one, in whose responsibilities they must join with us, so that the Doctrine should no longer be unilateral and its operation (defensive or otherwise) left to us alone. Of course, whether they joined or not, we should continue to support the Doctrine which originated with us and 


\section{A PAN-AMERICAN TRIANGLE FOR PEACE}

is so important to us. That step in advance has already been taken by them; thanks to the success of the A.B.C. mediation in preventing a war between the United States and Mexico. May the broadened scope of the recent coöperative offer to the Mexican factions of friendly offices by seven American republics be as successful in stopping civil strife as was the A.B.C. mediation in preventing an international conflict! Whether or not this second operation succeeds, it is an improvement on the first one because it strikes the true democratic note by rating the smaller nations as of the same importance as the larger ones. In any event, it is a splendid and a striking fact that such coöperative steps toward peace should have been taken on this side of the ocean at the same time that on the European side all coöperative effort is for war.

But is there no further step to be taken in the PanAmerican programme for insuring us peace, and is not the time now ripe for such an advance? PanAmericanism has produced a practical method for conserving international peace within this hemisphere, but can it not also produce an equally practical method of insuring peace for this hemisphere with Europe? I believe that there is such a step, and that now is the psychological moment to take it. In December, 1914, our South American friends initiated a joint effort to disembarrass all Pan-American waters 
from armed conflict between outsiders - an excellent suggestion and formulated in practical terms, as might be expected from nations so long trained in the study of international questions, a field which has interested our own people but recently. These Latin Americans looked forward into the future with the clear vision of a Washington or a Monroe, and realizing that immunity from European quarrels requires freeing our waters as well as our land from their armed conflicts or the possibility thereof, put forth a joint demand for such immunity.

Let us examine this reasoned request of theirs, and see if it will not disclose the nature of the next step now necessary thoroughly to complete the principle of our freedom from foreign complications urged by Washington and Monroe. The first point to consider is how such a request for neutralizing Pan-American waters might strike our friends in Europe, and what sort of a reply they would be justified in making. Would not a proper reply be that, because sundry European Powers have long possessed territory in the Western Hemisphere either on the mainland or on adjacent islands thereto, therefore they have the right to use such territory as military bases and to operate in the waters thereof? And is it not therefore the duty of every republic in this hemisphere to realize that if such a reply be a fair one, then Pan-American peace will never be completely assured until the ter- 


\section{A PAN-AMERICAN TRIANGLE FOR PEACE}

ritory of all the Americas is relieved from the sovereignty of any European Powers? Monroe could not go that far - he only opposed future colonization. There is an especial reason for urging a realization of this fundamental fact at this particular time.

It is very doubtful if ever again will the United States be in a fairer position to ask favors of Europe than it is at present, and it is vastly better to seek Pan-American peace as a favor than by force. And what is the position at present? Foreign loans and credits to European nations are being floated here as never before, and those nations in their need are turning to us as probably never again will they have to turn. Does not this state of affairs give us so peculiar an opportunity as to make of the opportunity a duty - a duty owed by us to all our sister republics, and to the majestic memories of Washington and Monroe? Is this not the psychological moment which those two great statesmen would have felt obliged to employ?

Should we not, therefore, say to our European friends: "In our opinion a graceful recognition of all we are doing and shall do for you - a graceful and noble recognition in whose appreciation all the Americas would join - would be to release to the sovereignty of the peoples themselves all colonial territory now owned by you in the Western Hemisphere. Canada can have her independence whenever she likes, but continues her connection with the British Empire by 


\section{MODERNIZING THE MONROE DOCTRINE}

her own volition. Offer the inhabitants of the Guianas, of British Honduras, and the other European colonies the same opportunity. Our South American brothers objected to the naval battle of the Falkland Islands being fought in Pan-American waters, but if those islands had been returned to Argentina, to which they are allied by propinquity and origin, they could not have been used as a naval base by a European Power, and the battle would have been fought elsewhere."

Such a request from us to the European Powers would be rich in that true altruism which is the backbone of Pan-Americanism as it is of the Monroe Doctrine, because we should be asking nothing for the United States, no territory, nothing - but everything for the liberty and assured peace of the Western Hemisphere. Besides, the request would come from a nation with clean hands, the nation which freed Cuba and then left her free, not once but twice. It is not unfair for us to ask others to act as we have already acted ourselves.

If for such a release of colonies the European Powers should ask financial compensation, there is no way in which the resources of our great country could be better expended in the cause of a free hemisphere than by paying such compensation, and in such payments participation by any of our sister republics would, of course, be welcomed. The time is ripe for such a request to free the soil of all the Americas, and 
none know it better than the European Governments. And why? We are being asked to list on our exchanges many of their loans, a privilege which every foreign Government controls, and for the concession of which they always require compensation. Let any one who doubts this statement study why Argentine bonds lost their quotation on the Paris Stock Exchange a few years ago, and how that quotation was regained, or inquire into any one of many similar episodes abroad.

In compensation for opening our exchanges to all these European loans, which means opening our pockets to Europe, it is our duty both to our fellow American republics and to our children's children, so that they may enjoy in peace their inherited liberties - it is our duty, I say, to complete and round out the immunity from entangling foreign alliances proposed by Washington and Monroe, by asking our European friends to liberate all territory in any of the Americas now held by them. In 1823 Monroe could only protest against future colonization by Europeans, but to-day it happens that we are in a position to ask and to pay for the release of all Pan-American soil from present European colonies.

Perhaps we of this generation may not live to see this full measure of our liberty come true, but surely, sooner or later, it will be realized. Perhaps it will come sooner than we may expect, for when, January 
9, 1913, I formulated the hope, so widely approved by the South American press, that in all Pan-American misunderstandings there should be invoked joint action by Pan-American countries, little did we think that by now it would be an accomplished fact, and an accepted method of insuring international peace in this hemisphere. Therefore, we may at least indulge the hope that there may also come into early flower this crowning blossom of Pan-Americanism - a hemisphere free from foreign domination or interference.

The foregoing was spoken to the University of Buffalo October 20, 1915. In all the United States there is no more appropriate locality for the launching of Pan-American ideas than Buffalo, for it was her farseeing citizens that had the vision to hold a Pan-American Exposition, thus splendidly advertising to all the world their appreciation of the increasing solidarity of all the Americas. Furthermore, it was at Buffalo's very doors that was held the Niagara Falls conference of the mediating diplomats of Argentina, Brazil, and Chile in the Mexican crisis, a mediation that was so important a milestone in our progress toward assured and permanent peace.

That the publication of this speech in the daily papers should have aroused sufficient interest to draw forth over one hundred editorials is of great value, not for anything said in the approving editorials 
(gratifying though they were), but because the criticisms advanced in the others brought all opposition arguments at once to the surface, thus enabling us promptly to clear the issue.

Before considering these criticisms in detail let me say that there seems to have been considerable misunderstanding concerning the distinction I made between Canada's situation and that of all the other foreign possessions in this hemisphere. The difference between them is so great that my suggestion should have needed no explanation, but it seems that it does, to judge from some of the published comments. Canada is a self-governing part of the British Empire, speaking the mother tongue. All other American colonies of foreign Powers are merely possessions, with the vast majority of their inhabitants speaking a language other than that of their owners. Although Canada has long been in a sufficiently strong and self-reliant position to demand and obtain her independence whenever she wished it, no other European colony in the New World has arrived at a position to have that opportunity, nor could any of them have it if they asked for it.

All the criticisms resolved themselves into six groups, as follows: That it is unfair thus to take advantage of Europe's temporary distress; that under no circumstances would the European Powers consent to sell colonies; that we could not afford to pay 
the millions necessary for their purchase; that they are better off as they are to-day than they would be if freed; that Latin-American republics had proved a failure in Santo Domingo and Haiti, and therefore similar failures would probably result if the colonies were freed; and, finally, that the Monroe Doctrine went far enough already by opposing future colonization, because no danger would ever come to us from the European ownership of existing colonies. These objections have been advanced by keen-minded editorial writers in many different parts of the country. None of them attempted to "play politics" with this new idea, but only to bring it squarely out into the open and to give it a fair discussion. This is as it should be, and it is doubtful if any new suggestion of national policy ever started in so clear and fair a fashion, stripped of all misunderstanding as this will be when answers have been offered to these six reasonable criticisms.

Let us consider them in order, and begin with the possibility of unfairness in now asking the European owners of colonies in our hemisphere to sell them ought we to advance such a proposition at a time when they are burdened with the dreadful distress and expense of such a war? And why not? And how could it be construed as an unfriendly act to offer them large cash payments at a time when they need cash more than ever before in their histories - at a 


\section{A PAN-AMERICAN TRIANGLE FOR PEACE}

time when their peoples are being taxed for war or for mobilization as they have never yet been taxed? When making the suggestion of this purchase, nothing was further from my mind than hostility to any of the European Governments concerned, and great as was my surprise at the point of view that could consider my suggestion as hostile to Europe, far greater still will be the amazement of their sorely tried taxpayers that so friendly an offer of much-needed cash could anywhere be considered otherwise than as a most welcome relief. The colonies they hold are now a source of taxation to them because they cost more to maintain than they yield, so not only would their sale produce money at a most opportune moment, but also it would relieve their present masters from their annual appropriations to meet those colonial deficits. No, there can be no danger of our offer to purchase being received in any other spirit than the friendly one which would actuate us in making that offer.

Next comes the second criticism, that the suggestion was visionary because none of the four European Governments (Denmark, Holland, France, and England) would under any circumstances entertain the idea of parting with any of the territory under discussion. The answer to this criticism came promptly, for two weeks after the press reported the Buffalo speech, the same newspapers published that Denmark was about to open negotiations to sell us her 
possessions in the Caribbean Sea. And even if the report of these negotiations did not answer this particular criticism, how do we know that none of those Governments would not consent to sell colonies unless we first make the offer? Does the history of any one of those four nations show anything to indicate that under no circumstances will they consider the relinquishment of colonial possessions? Did not England, the world's greatest owner of colonies, transfer Heligoland to Germany, and did not she very recently offer Cyprus to Greece for a consideration? But perhaps so feeble a criticism as this one seems to be was not advanced so seriously as were some of the next we shall examine.

Number three was the very frugal objection that we could not afford the millions it would thus require to Americanize the territory of all these colonies. In the first place, it is not necessary to assess this cost at any unreasonable figure. The colonies do not pay, and they certainly cannot represent any sentimental value to their owners, because the numbers of their owner's nationals living in those foreign possessions are extremely small. Perhaps it might be urged that these colonies have great strategic value for their owners as naval bases, and therefore those Governments would hold out for a high price. We have only to ask the question, "Naval bases against whom?" to shatter this argument, for these bases could only 


\section{A PAN-AMERICAN TRIANGLE FOR PEACE}

have strategic value if their present owners entertain hostile intentions against the United States, which happily is so ridiculous a hypothesis as to make it impossible for any Government to raise its price on that ground.

In this connection, suppose that in the present war England had not obtained control of the sea, and that Germany had made a land attack upon her in British Guiana or one of the British West Indian Islands, or in British Honduras near the Panama Canal. Is it not obvious how much more nearly that would have touched us under the Monroe Doctrine than did a seafight off the Falkland Islands? Should we not almost certainly have been drawn into this war? And ought not such a contingency to be eliminated, now that it is seen, and we are given the opportunity?

Supposing, then, that the prices would be reasonable, who shall say that the United States could not well afford to pay that total, or indeed many times that total, thus to guarantee its continued peace and that of our neighboring republics. It is true that it would be an act of altruism, but it is precisely in the field of altruism that our people always display the greatest national interest. How many millions did we not gladly pay to free Cuba? Did we not give back to China the twenty millions of Boxer indemnity she paid us? In passing, it is proper to remark that we were the only one of the several nations participating 


\section{MODERNIZING THE MONROE DOCTRINE}

in that indemnity which returned any part of it to China. How many millions have we not sent through our Red Cross Society to sufferers in other parts of the world? Did any one raise objections to the millions we have given to suffering Belgium and Poland, or does any one feel that we could not afford it, or indeed that we could afford not thus to aid stricken humanity? Away with all such traitors to the real spirit of our nation who would cavil at the expenditure of such an amount as would complete the blessing of liberty and republican government for all the peoples of the New World. The total cost of such a splendid act of altruism would not daunt a nation with the altruistic record that we enjoy. Even if we descend to the most sordid plane to discuss this sordid objection, even there it can easily be proved that the necessary expenditure for thus freeing us all from the danger of close-at-hand friction with European politics would be well worth our while, and could be written off against insurance or preparedness. Still another answer to this objection of cost will be found in Chapter XIII, where a plan of exchange instead of purchase will be suggested.

The objection, which if well founded would be the most serious of all, is that one which maintains that the colonies are better off as they are than they would be if freed. We could hardly claim to be enlisted on the side of humanity if the success of our efforts did not 


\section{A PAN-AMERICAN TRIANGLE FOR PEACE}

benefit the very fellow-creatures we are seeking to befriend. But is not this objection based upon a faulty knowledge of present conditions in those colonies? Even a cursory examination of standard reference books will reveal many surprises to admirers of European colonial systems. British Guiana is generally remembered as the territory the attempted extension of whose boundaries brought on our serious misunderstanding with England in 1895 so splendidly handled by President Cleveland. This surely is not a memory that inspires approval of continuing near-by European colonies. French Guiana is chiefly known for its penal colonies, in one of which Dreyfus languished for so many hideous years. Into this colony the French have introduced many Siamese and Chinese, just as the Hollanders have brought many Javanese into Dutch Guiana. No one will urge that such an intermixture of Oriental races tends to advance the manhood of those colonies, and it is in flat disaccord with the ethnological policy of the United States and of Argentina. Is it not fair to ask if such an intermixture of Siamese, Chinese, and Javanese shows any desire to advance the civilization of those colonies, or only a purpose to exploit them for their European masters with the cheapest labor obtainable?

How can any one advocate the continuance of a foreign rule with such results in citizenship as those shown by the 1911 census of British Guiana, when 
out of a population of 296,041 only 10,084 were whites, while 2622 were Chinese, 115,486 negroes, and 126,517 East Indian coolies, all brought there by the English to work the land for them. The first of the East Indian coolies were sent there in 1838 by John Gladstone, father of the great English Prime Minister. James Rodway, F.L.S., in his “Guiana, British, Dutch, and French" (1912), calls British Guiana the best of the three, and he says of it that "the people... can hardly be described as law-abiding ... Fortunes could be made a century ago, and good incomes forty years back. Now, however, the planter has to work very hard to make a small profit, and difficulties, once of little importance ... put the balance on the wrong side." Of French Guiana he says: "Cayenne is now a blot on Guiana and a danger to the other colonies. But it was not always so. The French colony could once compare with her neighbors; she was always a little behind, but not as she is to-day. Once there were plantations; only a few ruins indicate their sites."

Another fair question is that of how many miles of railroad have these foreign masters built to develop and improve the three Guianas, comprising as they do more than 171,000 square miles (with a population of about 430,000 ), a total equalling that of the States of Alabama, Georgia, and Florida, and almost as large as Ohio, Indiana, Illinois, and Iowa com- 
bined. There are 94 miles of railway in British Guiana, none in French Guiana, and 104 miles in Dutch Guiana, making a total of 198 miles for the three colonies, which total compares badly with Venezuela's 588 miles, or Colombia's 614 miles. Turning to British Honduras and comparing her railway development of 25 miles with that of the neighboring States, we find that Honduras has 175 miles; Costa Rica, 614; Guatemala, 350; Nicaragua, 191; and Salvador, 160. Thus again the comparison of a European colony with similar territory self-governed is unfavorable. The school systems introduced into the three Guianas by their foreign owners are either far below the average in other Pan-American lands or else do not exist at all. Venezuela, their next neighbor, has nearly $\mathbf{1 7 0 0}$ schools, while Colombia next to the west, has over 5000, both these countries being blest with ancient universities.

Let us turn to the colonial possessions in the Caribbean Sea and consider if European rule has advanced the interest of those islands. The population of the Danish West Indian islands steadily decreased from more than 43,000 in 1835 to less than 31,000 in 1901. In the Dutch islands business is not on the increase, and in 1910 the deficit of $\mathbf{9 2 2 , 5 8 6}$ guilders had to be met by an appropriation from the Dutch Government at home. The commercial statistics of the French islands tell a story which will hardly please 
those who claim that American territory flourishes better under foreign domination than it would under republican self-government. The French Colonial Office statistics for Martinique show a falling-off all through the long period from 1882 to 1907 , the annual imports dropping from $28,376,660$ francs to 15,940 ,039, the annual exports from 38,992,741 francs to $18,997,221$, and the total foreign trade annually of the island from $67,366,401$ francs in 1882 to 34,937 ,260 in 1907. The official statistics for Guadeloupe show an even worse state of affairs than those of Martinique. For the same period of 1882 to 1907 the imports fell off from $26,667,201$ francs to $13,625,855$, the exports from $41,811,642$ francs to $16,269,156$, and the total annual foreign trade from $68,478,843$ francs to $29,856,001$. Each of these islands is annually confronted with a deficit which France has to meet: in 1908 that of Martinique was 140,000 francs and that of Guadeloupe 400,000 francs. Compare these results of European ownership with the marvellous advance of Porto Rico under our charge. Perhaps the foregoing facts and many similar ones easily substantiated may prove unavailing to win over the objectors to freeing all European colonies among us, but if it does fail so to do, it will at least show the objectors in their true light.

The objection made by most of the adverse editorials was, that because Santo Domingo and Haiti 
have recently proved unsuccessful in their attempts at self-government, therefore none of these colonies should have an opportunity to test it, lest we might have to intervene later on. Those who make that argument either never knew or else have forgotten that those two island republics are alike in one respect, and in that very particular differ from all the other American republics - they are black republics, peopled by negroes far less prepared for self-government than are our negroes, who are generally well educated and self-supporting. All our campaign for Pan-Americanism has been based on the growing mutual recognition and appreciation of the Latin and the Anglo-Saxon. All American republics have Latin, Anglo-Saxon, or native Indian racial traits except Santo Domingo and Haiti, and they have African racial traits. That is why they differ completely from all the other republics, and why it is eminently unfair to predicate the failure of self-government in any other republic not peopled by Africans or their descendants upon the misfortunes of those two black States. Before leaving this point it might be pertinent to ask if those who bewail the difficulties of Santo Domingo and Haiti, and believe they would be better off as European colonies, would feel differently if those islands actually were colonies (and therefore naval bases) of Japan or Germany.

Perhaps the best way to recall the value of self- 


\section{MODERNIZING THE MONROE DOCTRINE}

government in the development of national character to all its belittlers, is to assert that their attitude spells a retreat from the civilization of the twentieth century to that of the early nineteenth, and then prove this assertion by showing them the wording of the first two articles of the Treaty of the Holy Alliance, signed in Verona, November 22, 1822, by Prussia, Austria, Russia, and France:-

"Article I. The high contracting Powers, being convinced that the system of representative government is equally as incompatible with the monarchical principles as the maxim of the sovereignty of the people with the Divine right, engage mutually, in the most solemn manner, to use all their efforts to put an end to the system of representative Governments in whatever country it may exist in Europe, and to prevent its being introduced in those countries where it is not yet known.

"Article II. As it cannot be doubted that the liberty of the press is the most powerful means used by the pretended supporters of the rights of nations, to the detriment of those princes, the high contracting parties promise reciprocally to adopt all proper measures to suppress it, not only in their own States, but also in the rest of Europe."

It is not difficult to meet the last of the six objections, that the Monroe Doctrine went far enough in 


\section{A PAN-AMERICAN TRIANGLE FOR PEACE}

opposing future colonization, and that we need not carry it on to completion by seeking to free existing colonies. If there was ever any sound basis at all for Monroe's pronouncement, it was because it expressed our desire to avoid the risk of becoming embroiled in European politics, to escape from which we opposed all future colonization because it might bring friction for us with their owners. This pronouncement is one of the pillars of our foreign policy, and yet, in all the years that we have espoused the Monroe Doctrine there has never been a time when we have been so near the very conflict Monroe sought to avoid as we were in 1895 with England over a boundary question between Venezuela and the colony of British Guiana, a colony which already existed in Monroe's time, and not one of the future colonies he opposed. If it had been possible for Monroe to have freed existing colonies as well as protect us against future European colonization, there would have been no Venezuela crisis, an international impasse from which but few of our Presidents could have promptly extricated us without war, and yet with both honor and credit. We cannot be sure always to have Cleveland's equal in the White House when such crises arise, so the best way to prepare for such a possibility is to go forward to meet it by eliminating in advance its cause.

With the Monroe Doctrine completed, and all American territory freed from the cloud of European 


\section{MODERNIZING THE MONROE DOCTRINE}

sovereignty, present as well as future, the purposes of both Washington and Monroe will be achieved, no more incidents like that of 1895 can arise, and better still, our relations with our European friends will be all the more cordial because those frictional possibilities will have been removed. Thus will there be erected the easterly side of the Triangle for Peace, shielding us from dangers that might arise across the Atlantic Ocean. 


\section{CHAPTER XII \\ THE PANAMA CANAL: ITS PART IN PAN-AMERICANISM}

Pan-Americanism makes for peace, and in "the piping days" thereof the Panama Canal, by facilitating intercommunication between the different sections of the hemisphere, is a potent factor of benefit and a great artery of that system. But there may come times when Pan-Americanism will be called upon to show its defensive strength under an attack from the outside. Great hopes have been built upon the canal's ability to double the striking power of our navy by making it possible quickly to shift fleets from one ocean to another. The advocates of a small navy say that this proves we do not need a great naval force in each of those oceans, because no longer is there necessary the long voyage made by the Oregon through the Magellan Straits in the Spanish War. All we would have to do, say they, is to transfer all our ships through the canal to whichever coast is attacked, because both coasts will never be attacked at once. All this is "important if true," to quote the motto of a great New York daily. Let us consider if the canal really can be relied upon to perform this important part in a defensive scheme. 


\section{MODERNIZING THE MONROE DOCTRINE}

In case of a war with the outside world, the first, or one of the first, blows to be struck by the enemy would be aimed at the canal. Hydroplanes would be launched from the decks of hostile war-vessels so near the Isthmus as to leave but a short aerial trip for the aviators seeking to drop bombs on the canal works. If only one out of the hundreds of bombs so dropped should hit a lock of the canal, gone would be the military value of the four hundred million dollars we spent on this great artery of American life. It has proved difficult to protect London from Zeppelin raids, and therefore we could expect no greater immunity in war-time for the Canal Zone. It will take more fighting ships to defend the approaches to the canal and to keep it open for operation, than it can be relied on to add to our naval strength by its transfer of ships from ocean to ocean.

Nor is an aerial attack the only danger that would threaten the operation of that great waterway. There is another and a more sinister one. If we cannot prevent our munition factories from being set fire to and blown up in peace-times, how can we expect that the Canal Zone will be kept free from the activity of similar gentry in war-time?

Pan-Americanism is richly worth defending, and its defense requires a strong navy in both the Atlantic and the Pacific Oceans, for the canal cannot be relied upon to make one fleet do the work of two. 
Pan-Americanism is being defrauded of a very potent assistance which the canal could render it if the Hay-Pauncefote Treaty did not tie our hands. If we were allowed a free hand in the management of the canal, we could grant preferential rates through it to all our sister republics, an act that would do far more for the political solidarity of Pan-Americanism than anything yet suggested or achieved. What is it that prevents our taking so neighborly a step?

The construction of an interoceanic canal was so hampered by the Clayton-Bulwer Treaty of 1850 that even England recognized the fact and consented to its revision. That veteran and distinguished diplomatist, General John W. Foster, once Secretary of State and father-in-law of our present Secretary, wrote that this treaty "marks the most serious mistake in our diplomatic history, and is the single instance, since its announcement in 1823, of a tacit disavowal or disregard of the Monroe Doctrine, by the admission of Great Britain to an equal participation in the protection and control of a great American enterprise."

Mr. John Hay, when Secretary of State, did his best to correct this outrageous state of affairs. Although he was one of the greatest diplomats we have ever produced and one of our four greatest Secretaries of State, even he could not obtain a complete abrogation of the Clayton-Bulwer Treaty. The result of his efforts was the first Hay-Pauncefote Treaty, 


\section{MODERNIZING THE MONROE DOCTRINE}

which was not approved by the United States Senate. By this one act alone the Senate thoroughly justified its possession of the power granted it by our Constitution to accept or reject treaties. Mr. Hay renewed his efforts and the result was a second Hay-Pauncefote Treaty, which, having received the approval of the Senate as the best that could be hoped for at the time, was promulgated by the President. We have scrupulously lived up to its terms and should continue to do so until England, either on her own motion or for compensation, consents to their modification or annulment.

Although the Hay-Pauncefote Treaty is less humiliating to our national pride than the Clayton-Bulwer Treaty, it is also open to the objection urged by General Foster because we are still hampered from without in the control of our canal. Taken together those two treaties are a monument to the superiority of English over American diplomacy, and at the same time are an affront to our dignity as a nation and to the territorial integrity of this hemisphere. We maintain the Monroe Doctrine for over a century, and then we alone and unaided build a canal whose operation England dictates! The history of our relations with foreign Governments shows that our representatives have generally been notoriously poor bargainers, but never have we come off so badly as in the ClaytonBulwer Treaty even as later modified by the HayPauncefote Treaty. 
The Hay-Pauncefote Treaty recites that its purpose is "to remove objections which may arise out of the Convention of the 19th of April, 1850, commonly called the Clayton-Bulwer Treaty, to the construction of such canal under the auspices of the United States, without impairing the 'general principle' of neutralization established in Article VIII of that Convention." England, having found that she overreached herself in the Clayton-Bulwer Treaty by so restricting canal construction that there never would be built a waterway so important to her, the leading maritime power, finally sees the necessity of modifying that treaty enough to get the canal built, but without however, relinquishing her participation in its control.

Let us see how much, if anything, England agreed to contribute in money or skill to the construction of the gigantic enterprise on which the French had already vainly expended millions: "It is agreed that the canal may be constructed under the auspices of the Government of the United States, either directly at its own cost, or by gift or loan of money to individuals or corporations, or through subscriptions to or purchase of stock or shares, and that, subject to the provisions of the present treaty, the said Government shall have and enjoy all the rights incident to such construction, as well as the exclusive right of providing for the regulation and management of the canal." All of which sounds very well, but in the event has 
proved that we cannot give preferential rates to our own or to our Pan-American neighbors' shipping. The entire contribution of England to the construction of the canal is her permission that we spend our money on it as we like. It would be comic if it were not so serious!

England now controls the Suez Canal, and although much French money went into its construction, still England also has large sums invested therein. But she managed to have us build the Panama Canal without a dollar of English capital being locked up therein. In the Suez Canal affair the French diplomats were out-generalled by the English ones, but not so badly as were we about the Panama Canal.

The plea that England makes of acting on behalf of all foreign merchant shipping, by insisting on equal canal tolls for all, is interesting, but not convincing, for the reason that she can and does build 'nd run ships cheaper than any other nation. This means that with equal canal tariffs for all, no shipping can transport so cheaply through it as she. She is safe in her supremacy so long as we are powerless to protect our own or our neighbors' shipping. The only way we can compete with her is to lower to her level the wages paid to those who build and navigate our ships, thus reducing our workmen and sailors to a scale of living repugnant to all who have at heart the real interests of American labor. 
What way is there out of the net in which we are caught? How can we regain freedom of action in conducting the canal upon the finishing of which we spent nearly five hundred million dollars and no other nation a cent - a canal which France had vainly tried to build, and which is so splendid a triumph for American brains? The only way is by obtaining a modification or annulment of the treaty either on England's own motion or in return for compensation. How can this be arranged?

Some day, when our State Department is approached by the English Government upon some matter interesting our friends across the water, our Department may point out that in view of our having built the Panama Canal with no outside assistance, and also because of the Monroe Doctrine, we should be gratified to have annulled both the Hay-Pauncefote Treaty and the Clayton-Bulwer Treaty which it superseded, and that such a friendly act by England would be a condition precedent to our favorable consideration of England's wishes in any other regard.

The Secretary of State who carries through this operation will live long in our history. Such a man will, by gaining for us freedom of action in canal administration, equip us for a forward step in PanAmerican solidarity far greater than any yet taken. May the day of such a national Defender of the Faith be not long in coming! 


\section{MODERNIZING THE MONROE DOCTRINE}

Not only should the Monroe Doctrine be completed by freeing all territory of the New World from European colonial control, but also, and for the same reasons of defensive seclusion from European politics, our great canal should be released from every vestige of foreign control.

There is yet another way of our securing the modification or annulment of the treaties hampering us in the Canal Zone. We will try to point it out in the next chapter. 


\section{CHAPTER XIII}

A PAN-AMERICAN TRIANGLE FOR PEACE

ITS WESTERLY SIDE: PRACTISING ACROSS THE PACIFIC WHAT THE MONROE DOCTRINE PREACHES

AND now, having discussed both the base and the easterly side of our Triangle, we have to complete it by adding the westerly side, to insure us a continuing peace on the Pacific. Unless I am mistaken, this third side of the Triangle will prove much the easiest to construct of them all, for it only depends on our willingness to correct our own point of view in matters Far Eastern. That done, the situation will rapidly clarify of itself. Are we or are we not willing ourselves to act west of the Pacific as we require other Powers to act to the east of it? The Monroe Doctrine appeals to our reason as well as to our patriotism, because it says, "Stay at home and mind your own business." For nearly a century we have preached this to all the outside world in regard to this hemisphere and now we are finding that peace never can be assured on the Pacific until our sister nation Japan becomes convinced that what we preach on our shores of that ocean we are willing to practise on its Asian coasts.

A danger from without, from across either the Atlantic or the Pacific Ocean, hanging over any republic 


\section{MODERNIZING THE MONROE DOCTRINE}

of the Western Hemisphere, must concern all other such republics, and there are many serious-minded people, both within and without the United States, who believe that we are in danger of a war with Japan. Why do they believe such a thing, and what safeguard against it can be evolved from our study of Pan-Americanism?

Let us not deceive ourselves by assuming that the conflict might arise from commercial causes - be a "trade war," so-called. Any strong national feeling in Japan against us would be caused by a belief that we have assumed an unwarranted position in Chinese affairs, talking too much about the "open door," as if it gave us special privileges; criticising the attitude of Japan toward China; and lastly but most serious of all, that our desire is to prevent the expansion westward of Japan. How shall we lay the ghost of that Japanese prejudice against our seeming pretensions to meddle in Far-Eastern affairs and how may PanAmericanism with its respect for others' viewpoints lead us toward this end, so promising of lasting peace on the Pacific?

What we need is to vaccinate our Far-Eastern policy with the "mind-your-own-business" vaccine of the Monroe Doctrine. What is "good medicine" for others ought to be good for us.

If we made it clear to all the European and FarEastern Powers, that just because we insist upon 


\section{THE PACIFIC OCEAN}

maintaining the Monroe Doctrine, we pretend to no rights in China other than those guaranteed all Powers under "most favored nation" clauses of treaties, then by this very act we should make more consistent and therefore stronger our position on the Monroe Doctrine with all those nations.

There is no use disguising the fact that many Americans feel that we are or ought to be the natural protector of China against what they call Japanese aggression. Neither can we disguise the correlated fact that until we exorcise that international bogey, we shall never gain that complete confidence of Japan which will spell continued peace on the Pacific. So long as we reserve the reasonable right to curb any and every outside nation from intruding on this side of the Pacific, we have absolutely no right to interfere with their expansion on the other shore, provided, of course, there be no infringement of our rights there secured by treaties.

Let us consider from what sources spring this dangerous nonsense of our being the natural protector of China. Of late years its chief cause is the very mistaken impression generally prevailing in our country concerning the "open door in China," and the special privileges believed to have been thereby secured for us by John Hay when Secretary of State.

Let us examine this fetich of the "open door," in which there has been aroused so much sentimental 


\section{MODERNIZING THE MONROE DOCTRINE}

interest with so little practical result, and the meaning of which is so widely misunderstood. In Japan they believe it to be an impudent assertion on our part of a right to intermeddle in Asian politics. This is a mistake, but no more of a mistake than is the interpretation generally put upon it in our country both by the press and by many individuals, basing their opinions on hearsay and not on the facts. Perhaps in China it is even more misunderstood than it is in Japan and in the United States, for there are many Chinese who seem to think that we are a sort of fairy godfather, especially devoted to protecting them against everybody and everything, whether they merit such protection or not. The sooner these various mistaken ideas be rectified the better, and there is no clearer or quicker way to true up our position than to test it by the standard of the Monroe Doctrine. Tried by that standard, is it not clear that in claiming any special rights or duties in China we are interfering in a distant business which no more concerns us than would a similar intermeddling in PanAmerican affairs by the Japanese be thought by us to concern Japan? "What is sauce for the goose is sauce for the gander." How should we like the Japanese press to begin a campaign for an open door in Cuba, despite the Platt Amendment?

It is no exaggeration to say that the phrase "open door" is as much misunderstood both here and abroad 


\section{THE PACIFIC OCEAN}

as the Monroe Doctrine used to be misinterpreted in South America. That latter ghost has been laid why let the former one continue to walk? Now, what are the facts? Of course, we have always claimed, and shall always continue to claim, the same rights in China, for trading or otherwise, which inure to all nations under the "most favored nation" clause of treaties. More than that we should never claim, and the sooner we take that stand frankly and officially, the sooner will there be dissipated all war-clouds over thePacific Ocean. To consider ourselves as the natural protector of China is dangerous nonsense. And yet a large number of our people believe that we have that duty toward China, and that because of that duty an "open door" has been arranged for us there which gives us certain valuable privileges. What those privileges are they do not know, but they firmly believe them to exist.

Let us see how that great Secretary of State, John Hay, effected the status commonly called "the open door in China."

The best way to understand this famous negotiation is to go back to the documents in the case. Under date of September 6, 1899, John Hay, then Secretary of State, sent instructions to our diplomatic representatives in Paris, Berlin, London, St. Petersburg, Rome, and Tokio, telling them to represent to the Governments to which they were accredited that the 


\section{MODERNIZING THE MONROE DOCTRINE}

United States would be glad not only to receive the formal assurances of each in regard to Chinese affairs, but also to have its coöperation in securing similar ones from the other Powers, so "that each, within its respective spheres" of whatever influence, might further the following agreement, which was the only portion of the various instructions alike in them all:-

"First, That it will in no way interfere with any treaty port or any vested interest within any so-called 'sphere of interest' or leased territory it may have in China.

"Second, That the Chinese treaty tariff of the time being shall apply to all merchandise landed or shipped, to all such ports as are within said 'sphere of interest,' (unless they be 'free ports'), no matter to what nationality it may belong, and that duties so leviable shall be collected by the Chinese Government.

"Third, That it will levy no higher harbor dues on vessels of another nationality frequenting any port in such 'sphere' than shall be levied on vessels of its own nationality, and no higher railroad charges over lines built, controlled, or operated within its 'sphere,' on merchandise belonging to citizens or subjects of other nationalities transported through such 'sphere' than shall be levied on similar merchandise belonging to its own nationals transported over equal distances."

Satisfactory answers having been received from all 
the capitals approached, John Hay sent the following instruction, mutatis mutandis, to our Ambassadors at London, Paris, Berlin, St. Petersburg, and Rome, and to our Minister at Tokio:-

Departuent of State, Wasuington, March 20, 1900.

Sir: -

The - Government having accepted the declaration suggested by the United States concerning foreign trade in China, the terms of which I transmitted to you in my instruction No. — of and like action having been taken by all the various Powers having leased territory or so-called "spheres of interest" in the Chinese Empire, as shown by the notes which I herewith transmit to you, you will please inform the Government to which you are accredited that the condition originally attached to its acceptance - that all other Powers concerned should likewise accept the proposals of the United States - having been complied with, this Government will therefore consider the assent given to it by $\longrightarrow$ as final and definitive.

You will also transmit to the Minister for Foreign Affairs copies of the present enclosures, and by the same occasion convey to him the expression of the sincere gratification which the President feels at the successful termination of these negotiations, in which he sees proof of the friendly spirit which animates the 
various Powers interested in the untrammelled development of commerce and industry in the Chinese Empire, and a source of vast benefit to the whole commercial world.

$$
\text { I am, etc., }
$$

John HaY.

It is useless to conceal the fact that although the conclusion of these negotiations was widely hailed by our press with the keenest satisfaction on the ground that Chinese affairs were forever satisfactorily adjusted, in many quarters abroad it was freely stated that the various Powers had been ingeniously trapped into a declaration which did not suit them, and that they had only replied favorably because the matter had skilfully been put to them in such shape that they could not afford to refuse coöperation. Nowhere abroad did they seem to feel, as did we, that this successful coup would forever guarantee the integrity of China. They, of course, had no objection to our continuing to believe that these "scraps of paper" were sufficient to protect a huge defenseless territory from the ambitions of six great and growing Powers, guided by later generations of statesmen and confronted by new problems and new conditions.

It was then and since then confidently believed by us that this door was really set open, and that we had special rights and duties in and toward China. That belief continued until a test of it was made. What 


\section{THE PACIFIC OCEAN}

happened the very first time we tried to use the door? We have seen that the third clause of the Hay proposal dealt especially with the railroad situation in China, and yet, when Secretary Knox, a practicalminded statesman, attempted to effect the international neutralization of the Manchurian railways, we found that the "open door" was locked and bolted! Those who still believe in the existence of that door to special privilege are dreaming a beautiful dream. They should awake to the fact that because the Monroe Doctrine forbids foreign intermeddling in the Western Hemisphere, we ourselves should not intermeddle on the Asian side of the Pacific.

But why does the phrase, "the open door in China," appeal so strongly to sentiment in the United States? Do not the roots of it run away back to the days when the New England clipper ships traded so profitably with China, and brought back such cupidity-stirring tales of the fabulous wealth of the Far East? Thanks to that foolish legislation, the Reciprocity Act of 1828, which took protection away from our merchant marine, our ships almost disappeared from the seas, but the memory of those Chinese profits and the stories of Chinese commercial possibilities persisted. But what are the facts? The foreign trade of Latin America is eighteen times greater than that of China, and the foreign trade of Argentina alone almost equals that of China and 


\section{MODERNIZING THE MONROE DOCTRINE}

Japan put together, and furthermore, it is increasing at a greater rate. The markets of Latin America are far more important and inviting nowadays than are those of the Far East, and this will be even truer in the future than it is in the present.

The fundamental ideal of Pan-Americanism is a willingness to give friendly consideration to the viewpoint of other nations. It was that which made successful the joint effort of Argentina, Brazil, and Chile to prevent a war between the United States and Mexico. Let us apply that attitude of mind to the Pacific Ocean problem, and pay the Japanese point of view the attention it deserves. If we are entitled to hold to the Doctrine which is so important to PanAmericanism, ought we not to be logical, and see that perhaps others may have similar rights and doctrines in their own continents? By interfering in China we are justifying Japan's interfering on our side of the water. We must not seem to forbid Japan's expansion to the east as well as to the west. It is not our intention so to do, but we must avoid even the appearance of such a high-handed piece of international interference. Not only is it physically impossible for us to enforce such an unwarranted policy, but also it is none of our business what Japan does to the westward, provided there be no infringement of our rights under the "most favored nation" clause.

Don't forget that the Monroe Doctrine has recently 


\section{THE PACIFIC OCEAN}

been recalled to the attention of the Japanese in a very decided manner by the action of our Senate in passing the so-called "Lodge Amendment." Since its promulgation, supplementing as it does the Monroe Doctrine by forbidding commercial companies to assist their Governments in getting footholds in the Western Hemisphere, has not Japan realized that we are taking one attitude toward her on the eastern side of the Pacific and a totally different one on the western?

That declaration of our Government, generally known as the "Lodge Amendment," came about in a manner best described by quoting the report made to the United States Senate July 31, 1912, by Senator Henry Cabot Lodge, of Massachusetts, on behalf of the Senate Committee on Foreign Relations:-

"On April 2, 1912, the Senate passed a resolution requesting the President, if not incompatible with the public interest, to transmit to the Senate any information in the possession of the Government relating to the purchase of land at Magdalena Bay by the Japanese Government or by a Japanese company. On April 30, 1912, the President replied to this resolution of the Senate by transmitting a statement in regard to the subject of inquiry from the Secretary of State.

"On the 16th of May, 1912, the Senate passed a second resolution asking for copies of the correspond- 


\section{MODERNIZING THE MONROE DOCTRINE}

ence relative to the American syndicate interested in lands on Magdalena Bay. On the 23d of May, 1912, the President replied to this resolution by transmitting the correspondence asked for by the Senate.

"These messages and the accompanying correspondence were referred to the Committee on Foreign Relations. After careful consideration of the subject thus referred, the Committee on Foreign Relations reports that it appears from the correspondence and from all the information that the committee has been able to procure that the Government of no other country has concerned itself with acquiring, or has made any attempt to acquire, possession of Magdalena Bay and the land about it. It appears further, however, from the evidence, that the corporations or persons who have, or claim to have, title to the lands surrounding Madgalena Bay have made efforts to form a syndicate and to promote the sale of these lands upon the basis of the existence of some national value to a foreign nation in Magdalena Bay, as distinct from any commercial value which that bay and the adjoining territory might possess. The fact that such an idea has formed the basis of a negotiation between the possessors of the title to the lands about Magdalena Bay and the citizens, subjects, or corporations of a foreign Power, seems to the Committee on Foreign Relations to afford an appropriate occasion for an expression of the view of the Senate of the 


\section{THE PACIFIC OCEAN}

United States regarding this and similar cases. For this reason the committee recommends the adoption of the following resolution:-

"Resolved, That when any harbor or other place in the American Continents is so situated that the occupation thereof, for naval or military purposes, might threaten the communications or the safety of the United States, the Government of the United States could not see, without grave concern, the possession of such harbor or other place by any corporation or association which has such a relation to another Government, not American, as to give that Government practical power of control for national purposes."

Even more important than the correction of foreign misinterpretations of our attitude and intentions is the need for setting our own people right in this FarEastern question. We are not the natural protector of China, and there is every reason that we should not wish to assume that responsibility. Our position should be scrupulously restricted to that so admirably set out in the formal exchange of notes November 30 , 1908, between Elihu Root, Secretary of State, and Baron Takahira, the Japanese Ambassador: “(4)They are also determined to preserve the common interests of all Powers in China, by supporting, by all pacific means at their disposal, the independence and integrity of China, and the principle of equal opportunity 


\section{MODERNIZING THE MONROE DOCTRINE}

for commerce and industry of all nations in that Empire."

A good deal has been said of a certain joint cablegram extensively quoted from in the public prints of April 18, 1915, as having been "recently sent" to the President by American missionaries in China, protesting against certain Japanese actions toward China. This cablegram was said to contain over five thousand words, and characterized Japanese demands on China then under consideration as "acts of aggression such as eventually will present a menace to the United States." It asked the President to demand from China participation for us in the conferences then proceeding between the Chinese and Japanese authorities. I for one am unwilling to believe that the earnest and devoted men who signed that cablegram had any intention of embroiling the United States with Japan or any wish to have our nation use force on behalf of China, because any such intention or wish would have been so contrary to the peculiarly honorable custom of American missionaries in this regard all over the world. We are especially proud of them because the religion they carry with them has always been a personal religion and never a national religion. They have never sought to gain territory for our flag, but only to bring the divine truth to the individuals they reached. Our German friends allege that it was the English missionaries who secured 


\section{THE PACIFIC OCEAN}

Uganda for the English flag, and our British friends retort that the murder of two German missionaries in China enabled the German Government to demand as compensation many square miles of valuable territory at Kiao-chau, which they seized November 14, 1897. Without discussing the merits of these and many similar allegations, it is a great comfort to us as a nation, and a ground for pardonable pride, that nothing of that sort has ever been charged against our missionaries. They are not political propagandists and do not wish to embroil our Government with other Governments, and for that reason we may be sure that the missionary cablegram from Peking cannot be taken as an argument for the United States interfering as special defender of China against Japan. We made no protest against the German invasion of Belgium: how does China differ from Belgium?

And now we come to our most vexed problem the Philippines, and what to do with them. Our misconception of the "open door" is not the only particular in which our national attitude on Far-Eastern affairs fails to true up to the standard we erected in the Monroe Doctrine. So does our possession of the Philippines. We hold those islands as the chance result of war, and not because of any lust for territory or any desire for a foothold in the Orient. But what must be the Japanese point of view on this subject? Is it not natural for them to wonder how we can con- 
tinue persistently to object to foreign colonization in the Western Hemisphere while we are actually in the possession of large colonies near the coast of Asia? How should we feel if Japan came into possession of some of the West Indian islands - would it not affront the Monroe Doctrine? The Japanese must feel the same about our holding islands in the Orient as we should about seeing their flag hoisted in the Caribbean Sea. Why, then, should we be good PanAmericans in the Caribbean Sea and not ourselves practise the same stay-at-home-and-mind-your-ownbusiness policy in the Orient?

This Philippine problem is not at present being met in a way that is satisfactory to any of us. Why can it not be met so frankly that out of its very difficulties a valuable result can be evolved, just as the Mexican crisis proved a blessing in disguise by bringing into existence the Pan-American mediation machinery, which, great as is its value already, will prove even more valuable as it develops?

Our possession of the Philippines does not true up to the Monroe Doctrine and its "mind-your-ownbusiness" basis. But neither does the possession by Denmark, Holland, France, and England of colonies in this hemisphere, nor the existence of the HayPauncefote Treaty controlling as it does our Canal. Why not set off one of these sets of discordant facts against the other - trade the Philippines for all 


\section{THE PACIFIC OCEAN}

European possessions to the south of us, plus freedom of hand in the Panama Canal by an agreed annulment of the Hay-Pauncefote Treaty, and then turn the Guianas and British Honduras into free republics, return the Falkland Islands to Argentina, and take under our own flag the West Indian Islands, so important to the defense of the great Canal? Thus at one step we should eliminate Japanese distrust caused by our holding the Philippines, honorably release us from the responsibility for those islands, complete the protection from European entanglements initiated by Monroe's protest against additional European colonization, and, finally, free us from European military bases near the Panama Canal, and foreign control of the Canal's operation.

Some may ask, How would the Philippines be divided among those four Powers? That would be for them, not for us, to decide. But it is clear that the division would be simplified by the fact that England's share of the American colonial possessions to be relinquished is so much greater than that of the other three Powers as to make her obviously the leading trader in the transaction. Our friendly relations with her, the most interested European party to the trade, and her friendly relations with her threepartners therein, Denmark, Holland, and France, would combine to facilitate both the trade and the subsequent division of the Philippines among the four acquiring Powers. 


\section{MODERNIZING THE MONROE DOCTRINE}

This suggestion that we exchange the Philippines for European colonies in this hemisphere was made by me December 30, 1915, in Washington, at the banquet given by the Carnegie Endowment for International Peace to the American Society of International Law, the American Political Science Association, the American Society for Judicial Settlement of International Disputes, and Section 6 of the Second Pan-American Scientific Congress. It seems to me significant that while nearly half of the editorial comment on my suggestion, two months earlier, that we purchase near-by European colonies, was adverse, almost all newspaper comment was favorable to the plan of exchanging the Philippines for them, only two or three of the many editorials opposing it. I take that unanimity of approval to mean that this is thought to be an honorable way out of the Philippine dilemma.

The Philippine problem is a most difficult one in peace times, but suppose we get into a war - what then? They must either be evacuated or defended; there is no middle ground. What a national disgrace it would be to have to evacuate them, and how we would regret the failure to have already honorably and profitably traded them for more defensible territory! Suppose instead of evacuating them we undertake the other alternative of defending them - what a task that would be. Have we the fleet to guarantee the safe forwarding of the necessarily large reinforce- 


\section{THE PACIFIC OCEAN}

ments? - or the transports to carry them? - or even the reinforcements? Merely the asking of those three questions is enough to show how disheartening is the hope of answering them. The defense of those islands would be only one part of our general system of defense; a chain is only so strong as its weakest link, and the Philippines would prove a sadly weak link. Let us go forward to meet this problem, and exchange those far-away lands for others nearer at hand.

By some it may be urged that we must continue our possession of the Philippines until such time as we have fully trained them for self-government. When will that be, and why must we? - a double question most difficult to answer. The treaty of peace with Spain, signed at Paris December 10, 1898, gives no hint of our ever leaving the Philippines, although in its Article XVI it refers to such a possibility regarding Cuba as follows: "It is understood that any obligations assumed in this treaty by the United States with respect to Cuba are limited to the time of its occupancy thereof; but it will upon the termination of such occupancy, advise any Government established in the island to assume the same obligations." Indeed this treaty distinctly implies that our possession of the Philippines will be permanent because by Article IX we guarantee all "their rights of property" to "Spanish subjects residing in the territory over which Spain by the present treaty 


\section{MODERNIZING THE MONROE DOCTRINE}

relinquishes or cedes her sovereignty," and we agree that "they shall also have the right to carry on their industry, commerce and professions."

Why is it that we must take upon ourselves this great responsibility of training and freeing the Filipinos? It certainly was not for that purpose that we took the islands. It was not part of any contract in taking over the islands. Indeed, the only contract that existed at the beginning of the enterprise was the one undertaken by Admiral Dewey - to seek out and destroy the Spanish fleet. His search took him into Manila Harbor, where he carried out the contract of destroying the hostile fleet. It also became necessary to overcome the land batteries aiding that fleet. These operations resulted in giving us a foothold in those islands, which foothold was, by the exigencies of war, expanded into a complete conquest of their diverse populations. Of course we did our best to improve the conditions under which we found them living, and it is doubtful if history can show, in so short a time as has elapsed since the Spanish War, so marked an improvement in any colonial possession held by any Power. No sooner had we become settled in our possession of those distant islands than the feeling began to grow among us that they were more of a debit charge on our national ledger than an asset. They were too far off, they were populated by many alien races, they were more difficult to protect in war 
than could be offset by their value in peace. So we began seeking some solution of the riddle - how, honorably, to rid ourselves of this burden.

The first and almost the only solution to present itself was, as is customary in our history, an altruistic one: "Let us educate the Filipinos up to" the level of self-government and then free them." Let us educate lambs to self-government and then free them in the forest! The solution was unpleasing to the practical, and appealed strongly only to the unpractical, but no other way out appeared, and therefore many of us half-heartedly endorsed the plan. The further we have progressed in its development the more unsatisfactory does its conclusion appear. It is a plan which keeps them in a constant discussion as to how soon that freedom is coming, meanwhile keeping hung over our head, like the sword of Damocles, the undesired and unnecessary perplexity of deciding the exact moment when we can safely withdraw and leave them to themselves. This combined attitude of schoolmaster and manumitter used to seem the only way out of the dilemma in which the possession of these distant colonies has put us, and yet it satisfies nobody. Certainly not us, and least of all the Filipinos, who are clamoring for immediate freedom. Sensible public opinion sees that the time is not yet. When will it come? - Who shall decide? - Shall we ever agree on the point? 
And if it does come, and after we have retired, they fall out among themselves, must we intervene to reestablish sound government as we did in Cuba? God forbid! Cuba is a near-by, homogeneous nation of an old civilization. The Filipinos are a distant, widely diversified people divided among many islands, many of them with no civilization at all, or only a recent veneer of it. Cuba is near us, while the Philippines are near Japan. Suppose one small political faction of the freed islanders, in order to gain governmental control, should intrigue with some political faction in Japan - what an amount of international friction might it not engender.

Would one intervention suffice to reëstablish a lasting administration of justice and government among a freed nation of such contrasting racial types and such wide differences in civilization? Must we not foresee a series of such interventions looming up to plague us?

For us to guarantee Philippine independence after our withdrawal would mean even a greater responsibility for our army and navy than does our present control of those islands. It would take more men and ships than it does to hold them. And yet to give them independence without guaranteeing it would be but a sorry trick, and would mean only a petty political shift to escape from our present responsibilities.

Distant though those islands are from us, they are 


\section{THE PACIFIC OCEAN}

administratively convenient to the English in Australia, Hongkong, Shanghai, and the Straits Settlements, to the French at Tonkin, to the Dutch in Java, Sumatra, and Borneo. To those nations the Philippines would prove additional assets in the Far East, while to us they are but an unending problem becoming more difficult every year as the clamor for independence increases. All those nations have successfully conducted colonies in those seas, and may be trusted to administer the Philippines with equal success. If England shall, after obtaining from us her share of the Philippines in exchange for Caribbean territory, effect some arrangement touching them with Japan, then we may confidently hope for such Filipinos as become Japanese subjects the same advantages that the Koreans have of late years experienced. Nothing should rise up to plague our national conscience, for the Filipinos would gain more in the end in those hands than they will from a consummation of our present unpractical plan of teaching lambs selfgovernment and then freeing them in the forest!

If any one shall raise the plea of humanity, and say that it is our duty to train and free the Filipinos, I should reply that the charity they describe begins best at home. I for one am vastly more concerned in guaranteeing peace in the New World during the lifetime of my little son than in minding other people's business on the other side of the globe. Let us 


\section{MODERNIZING THE MONROE DOCTRINE}

eschew distant responsibilities till we have progressed further with those at home. Any inhumanity which might be alleged against our relinquishing for a consideration the Philippines to any other Power or Powers is as nothing by comparison with a bloody war between us and some nation brought on by our owning those islands. Both reason and ethics demand that we consider our own people before we undertake reforming any portion of the Orient. Let us by all means and promptly avert that danger, especially as by the suggested trade of those islands we can at the same time avert the recurrence of the danger which in 1895 arose over the Venezuela boundary with England. Two dangers eliminated at one and the same time, all parties to the trade advantaged by it, and our relations with Japan also greatly ameliorated - "a consummation devoutly to be wished!"

The Philippines are an asset won in war. To give them up for nothing has been properly described as "a policy of scuttle." To exchange that far-distant asset, pregnant of trouble, for a near-by asset completing the peaceful seclusion of our hemisphere, is good business, good international politics, and a long step toward "peace on earth, and good-will toward men."

There are three great services which Pan-Americanism can render to the millions residing in the Western Hemisphere; first, it can prevent interna- 


\section{THE PACIFIC OCEAN}

tional conflicts between the republics of the Americas; second, it can safeguard us against frictional misunderstandings with Europe; and, third, by reminding us to mind our own business and stay at home, preserve for us a lasting peace on the Pacific. The successful operation of the A.B.C. mediation in preventing a war between the United States and Mexico has set up a piece of machinery which should always be able to effect the first of these three great purposes. As to the second, we have seen in an earlier chapter how a relinquishment by the European Powers of all their colonies here would eliminate the last possibility of the friction which Monroe strove to reduce by opposing further colonization. To complete the trilogy of services by laying forever the ghost of possible hostilities with Japan, and thus safeguard our peace to the westward as well as to the eastward and at home, let us, true to the altruistic ideals of PanAmericanism, respect the viewpoint of the Japanese by promptly announcing that we prefer their friendship to our exaggerated misunderstanding of the "open door in China," and also by exchanging distant and undesired territory near Japan for other which will complete for the hemisphere of our homes the peaceful seclusion from European politics we have always sought. Thus shall we arrive at a permanent basis of peace with all the world for all the republics of all the Americas. Thus will the Triangle of Peace 


\section{MODERNIZING THE MONROE DOCTRINE}

symbolize harmony throughout our hemisphere and a defensive separation from troubles arising beyond our two ocean boundaries.

If it shall seem best to set up this Triangle, then with a foreign policy so productive of peace at home and protection from outside attack from across both the Atlantic and Pacific Oceans, we of the New World may tranquilly proceed to the development of our own untouched resources, a development which is to be the world's next great step forward. 


\section{CHAPTER XIV}

\section{A STRENGTHENING OF THE LATIN-AMERICAN}

MAP

In this book we have spoken not only of the changing relations of the great Southern continent to us and to the rest of the world, but also there have been ventured some new suggestions made in the hope of realizing from the betterments already achieved by PanAmericanism, even greater benefits in the future for the hemisphere which to Pan-Americans means home - home with its responsibilities as well as its delights. It is clear that the fixed policy of the United States is forever to refrain from taking any territory from any of our fellow republics. No such changes in the map are in prospect, nor should they ever be possible. But is it not probable that certain changes will take place in that portion of the map belonging to Latin America, not changes born of aggression, but those making for the real strengthening of existing governments by combinations thereof? Why should we not seek to draw aside the curtain beyond which lies the future? Perhaps it might be we ourselves who, by some act of national altruism, could initiate such a tendency to combine as would make of such unions greater strength for our neighbors - our friends. 
Suppose that either by a money purchase or by offering in exchange the Philippine Islands we could eliminate Europe from all her colonial possessions to the south of us and also her interference with our control of our Panama Canal, should we not, by gaining such freedom for colonies and canal, not only make a substantial contribution to true Pan-Americanism, but also materially improve our own chance for continued tranquillity in the future? Does not this also provide a reasonable and honorable solution of the vexed Philippine problem?

But if all these colonies should be freed from their European masters, there at once arises the interesting problem of what is to be done with them - are they to be started as independent republics or are they to be joined to some neighboring commonwealth? If the alternative of making them all independent should prevail, can we blind ourselves to the fact that some of them are really too small for such a lot, and also that in no case have their European masters equipped them, either politically or by the physical development of their territory, for any form of self-government? If it be suggested that all such freed land be turned over to some adjoining republic, would not the prospect of such territorial largesse arouse unfortunate discussion (to say the least!) as to which country had the better right to them for either historical or geographical reasons? No; either one of these possible 
adjustments would, if sweepingly adopted, cause unnecessary difficulties. Let us see if there is not some safe middle ground along which there can securely proceed an orderly rearrangement of geographical lines which shall not only benefit the liberated colonies, but also at the same time strengthen all existing governments in South and Central America.

Because this is a Latin-American problem, we must begin by adjusting ourselves to their point of view, or at least do so as far as we possibly can. If we do not try so to do, we may evolve a plan that will suit us, but almost surely it will not meet with the approval of the very people most concerned. Starting, therefore, with a determination constantly to consider the South American viewpoint, what better plan can we Anglo-Saxons devise for the major portion of the freed territory, the three Guianas, than to make them further the statesmanlike project of Bolivar, the liberator of the northern part of that continent from the Spanish yoke? Why should we not, by our gift of the Guianas, powerfully help to reconstitute the New Granada or greater Colombia of his dreams - a splendid confederation of the Guianas with Venezuela, Colombia, and Ecuador? The flags of those three republics are so similar as to bear striking testimony to their historical relations in the past, and further, would make very easy the selection of the national flag of this new and powerful republic, so much more 


\section{MODERNIZING THE MONROE DOCTRINE}

powerful in combination than are all of its integral parts as separate States.

Nor can the lack of railway intercommunication be fairly urged as an argument against such an assembling of the parts into a whole, because the united country would enjoy a continued sea front on the Caribbean Sea, and, through the Panama Canal, along the Pacific Ocean. This continued littoral would provide the same sort of sail and steamship connection and cohesion as does for Chile its longer Pacific shore-line. Back from the sea there still exist the old Spanish carreteras, or cart roads, connecting all this inland country, and it is surprising to learn how much they are still used by the Indians to transport their wares such long journeys as that from lofty Quito down across Colombia and on to interior Venezuela. If the reader will take up some modern map he will be surprised to see how many large rivers, feeders of the Orinoco, that great artery of Venezuela, extend westward far into Colombia and Ecuador, thus providing still another and a cheap channel of communication between those districts.

If there should arise a conflict of claims among the capitals of the existing republics for the honor of obtaining the seat of the new federated government, a solution could be found by turning to the writings of sundry statesmen of those very countries, where are to be found suggestions of some neutral inland and 
central point, so situated at the junction of interior lines of communication as to please all by its ready accessibility. Such a point. would be San Fernando de Atabapo, in western Venezuela. It was of this town that Humboldt says (reporting trips made by him from 1808 to 1814): "San Fernando de Atabapo stands near the confluence of three great rivers [Orinoco, Guaviare, Atabapo]. Its situation is similar to that of St. Louis . . . at the junction of the Mississippi with the Missouri and the Ohio. . . . In proportion as the activity of commerce increases by these immense rivers, the towns situated at their confluence will become centre points of civilization." He predicted so correctly the future of St. Louis that this great geographer may yet prove right about San Fernando de Atabapo. However, any such minor questions as the location of the capital would fade into insignificance beside the realization of the New Granada of Bolivar's dreams, a stately republic with a population of ten and a half millions, with a commanding position on the Caribbean Sea and a shoulder on the Pacific a considerable nation with much more voice in the family of nations than have the divided States of Bolivar's house as they now stand. In passing, it is important to notice that all these northerly peoples, so assembled under one flag, could not fail to recognize our altruism in rendering that assembling possible by our purchasing the release of the three Guianas. If 
it obtained us no other advantage than regaining us the good-will of Colombia, it would be well worth while.

Another possible readjustment would be the allocation of French Guiana, the most easterly of the three, to Brazil, thus completing on the north the eastern coast-line of that republic, while Dutch and British Guiana would go to complete the north-coast republic of their neighbors on the west.

While speaking of Brazilian boundaries it is highly appropriate to remark that no consideration of the map of South America would be complete without a reference to that great Minister of Foreign Affairs, Baron Rio Branco, of Brazil. During his long tenure of office he devoted himself unceasingly to the adjustment of boundary disputes between Brazil and her neighbors. Because she joins boundaries with every other country of the continent but Chile and perhaps Ecuador (whose boundary disputes with Colombia and Peru might, if decided against her, cut her off from Brazil), his labors in closing up so many disputed questions contributed greatly to guarantee peace by eliminating many long-standing elements of friction.

I well remember it was generally remarked that the delegates of the different Central American States to the Fourth Pan-American Conference, at Buenos Aires in 1910, were, if taken together and considered as one delegation, in every way equal to the delega- 
tion sent there by any of the larger republics of the mainland, strong as some of the latter undoubtedly were. "In union there is strength," and if the Central Americans had represented one larger instead of so many smaller States, they would have had even a larger voice in the councils of that convention than they enjoyed.

Every well-wisher of the Spanish-speaking republics will agree that just as such a confederation would strengthen the political and economic position of the northerly states of the mainland, so a similar combination of the Central American Republics would also benefit them and lend importance to their federation. The stronger all such groupings of republics become, the less they are apt to fear and therefore distrust us, and anything which tends to diminish that distrust is of great value to all concerned. Furthermore, the stronger such groupings become, the better able are they to take their part in causing the territory of this hemisphere to be respected by outsiders.

And how can we best help in bringing into being such a Central American Federation? Could any argument on its behalf coming from us be more effective than the obviously altruistic one of offering to add to its united territory that of British Honduras if and when the plan of freeing all these foreign-owned colonies shall have been effectuated? This offer could be made conditioned on the agreement of the other 
republics to unite into a confederation which should receive this additional territory. In this connection, because one of those States, Nicaragua, has already accepted the principle of the so-called Platt Amendment (by a signed treaty not yet ratified by our Senate), which gives the United States certain rights in regard to the relations of Cuba with the outside world, it is our duty frankly to speak of the terms of that document, for such a book as this would be incomplete without its inclusion. It is common knowledge that this amendment was drafted by Elihu Root while Secretary of State, but bears the name of Senator Platt of Connecticut, because it was he who introduced it into the Senate. The portions affecting the foreign affairs of Cuba are as follows:-

"Article I. The Government of Cuba shall never enter into any treaty or other compact with any foreign Power or Powers which will impair or tend to impair the independence of Cuba, nor in any manner authorize or permit any foreign Power or Powers to obtain by colonization or for military or naval purposes, or otherwise, lodgment in or control over any portion of said island.

"Article II. The Government of Cuba shall not assume or contract any public debt to pay the interest upon which, and to make reasonable sinking-fund provision for the ultimate discharge of which, the ordinary revenues of the Island of Cuba, after defraying 
the current expenses of the Government, shall be inadequate.

"Article III. The Government of Cuba consents that the United States may exercise the right to intervene for the preservation of Cuban independence, the maintenance of a government adequate for the protection of life, property, and individual liberty, and for discharging the obligations with respect to Cuba imposed by the Treaty of Paris on the United States, now to be assumed and undertaken by the Government of Cuba."

Inasmuch as Nicaragua has accepted the principle embodied in this Platt Amendment, its entry into a Central American Confederation would necessitate negotiation concerning that amendment with the new combination. As British Honduras would probably be offered by us also protected by this amendment, it might be that under these new circumstances and in consideration of our freeing British Honduras, the other States, Honduras, Panama, Guatemala, Costa Rica, and Salvador, might care to have the new and greater republic accept our coöperation in this regard. It is a matter for negotiation, but that it must be faced could not be overlooked here.

The West Indian Islands now belonging to nations of Europe would, if purchased by us, lie in very different case from the other colonial possessions similarly released by us from their foreign owners. The territory on the mainland could, as we have seen, be added to 
existing republics adjoining them and thus serve the threefold purpose of strengthening those republics, of improving their own condition by the practice of self-government, and lastly, of advancing the cause of Pan-Americanism by showing added proofs of our altruism toward it. But there would be no free territory directly adjoining the purchased West Indian islands, and furthermore, they are important defensive points which we should hold, because it is our duty to the whole hemisphere to neglect nothing which may defend for all of us the free use of the Panama Canal. For this reason, if for no other, we should retain under our flag such of those islands as we may acquire by purchase, except the few which lie against the Venezuelan coast and therefore should go to that republic. But in the freeing of the Falkland Islands from English rule, no such geographical reason or defensive duty obtains, and those Falkland Islands should therefore be restored to the Argentine Republic.

What we have said thus far closes all that portion of map alteration which could be furthered by our gifts of newly freed territory. We now turn to an entirely different state of affairs, existing far away to the South, at the other end of the continent, away down in the temperate latitudes, where climate is aiding progress in many ways, of which immigration is not the least important. 
What is the state of affairs that we shall find existing among those forward-looking peoples? Already there has been recognized the value - the worldsignificance - of combining units to form a whole on external questions. Already this realization of world-tendencies has taken shape in certain political engagements entered into by Argentina, Brazil, and Chile by means of several recently signed treaties which together result in what is popularly known as the "A.B.C. Alliance." Those treaties are doubtless serving a useful purpose because they make for a better understanding between the contracting nations. Nevertheless, it is to be doubted if those treaties will in the more or less distant future prevent a changed alignment in that part of the world, a more natural combination, based on common language, climate, and racial tendencies.

How long can there be deferred in that part of the continent a confederation which the rapidly increasing ties of railroad and river connection between republics having the same language and institutions, as have Argentina, Chile, Bolivia, Paraguay, and Uruguay, would seem naturally to make of them? The Andes, which so long kept Chile and Argentina apart, are already conquered by one railroad and soon will be by others, and those great mountains will prove no more of a political barrier between those peoples than does the lofty Sierra Nevada range separate 


\section{MODERNIZING THE MONROE DOCTRINE}

California from the rest of the United States. There are not a few who believe that if and when a political union is effected between Chile and Argentina, the former, though placed as is California in our Union of States, will be rather the Ohio of the combination, which means that the statesmen of what is now Argentina will have to look to their political laurels in the new confederation, lest the Chileans snatch them away.

As for Bolivia, the two railways now connecting her with Chile, and the new line between $\mathrm{La} \mathrm{Paz}$, her capital, and Argentina, will prove strong arguments for Bolivia's joining a confederation having all its political elements in common with hers.

Just as Bolivia would be linked with a combined Chile and Argentina by three great railway arteries, so Paraguay has its capital, Asuncion, already connected both by railway and by steamship with Buenos Aires, the majestic metropolis of all South America. That enormous artery of trade, the River Plate, is so much greater than any of our own rivers that it is difficult to make our people understand what a highway of commerce it affords from Montevideo, the capital of Uruguay, stationed at its mouth, all the way up to Asuncion and beyond, a huge physical argument for the union of Paraguay, Uruguay, and Argentina. One has only to live a few months on either bank of this great river to learn of the close affiliations al- 
ready existing between Buenos Aires and Montevideo, as well as between the nations of which they are the capitals, - ties not only of commerce and race, but also of frequent intermarriage.

The more one comes to know of the people and conditions of that part of the world, the more irresistible becomes the conclusion that some such combination of their Spanish-speaking republics will ensue. This alliance between Argentina, Chile, Bolivia, Paraguay, and Uruguay is a natural one, and would bring into being a united and majestic nation of eighteen million souls, a balance in their temperate latitudes to the great Portuguese-speaking republic of the tropics, Brazil with her twenty-one millions.

Whether Peru would ally herself with the New Granada grouping of the north or with this larger five-nation confederation of the south, both of them speaking her language, will depend on many things, not the least of which would be the matter of railway communication. Peru was formerly the seat of the Vice-Regal Government controlling all the Spanish colonies, and the Peruvians have excellent reasons for being the proud race that they are. Whichever of those two groupings gains her adherence will thereby greatly enhance its prestige and importance in more ways than by the addition of her four and a half millions of population.

Perhaps there is here sketched nothing but the 201 


\section{MODERNIZING THE MONROE DOCTRINE}

dream of a dreamer, but at least it seeks to advance the political importance before the world of his friends in the Southern continent.

Out of the melting-pot of the great European War blessings have already come, and more will follow. Already France and Russia are regenerated throughout every fibre of the body politic. During the last months British patriotism has flamed up as never before in the memory of living men. Before peace comes none will benefit more than the fine German people by freeing their individual and personal rights from the control of military officialdom. And what of us? Shall we content ourselves with mere material gain from this dreadful world-crisis? Should not we also take thought for the Spirit of our Nation, and collectively consider how our destinies should be shaped so that our children and their children shall enjoy the land that has been given us?

It is related that Lincoln, during a time of great stress and trial, told a friend that, while in early life he had always striven to have God on his side, in later years he had come to realize the supreme importance of being on God's side in a crisis. May not those who join the crusade for a progressive Pan-Americanism feel that through its consideration for the point of view of other nations they are aligning themselves as Lincoln strove to do in his 


\section{STRENGTHENING LATIN AMERICA}

riper years? And if the alignment be of that high character, can there be any doubt of success for the crusade, or that the Spirit of ' 76 will be revived among us? 
(Cbe thiturergide preg

CAMBRIDGE - MASSACHUSETTS

$\mathbf{U} \cdot \mathbf{S} \cdot \mathbf{A}$ 




\section{PLEASE DO NOT REMOVE CARDS OR SLIPS FROM THIS POCKET}

\section{UNIVERSITY OF TORONTO LIBRARY}

JX
1425

Sherrill, Charles Hitchcock Modernizing the Monroe doctrine 
